UNIVERSIDADE DE SÃO PAULO

FACULDADE DE FILOSOFIA LETRAS E CIÊNCIAS HUMANAS DEPARTAMENTO DE FILOSOFIA PROGRAMA DE PÓS-GRADUAÇÃO EM FILOSOFIA

ANTONIO SERGIO DA COSTA NUNES

A arqueologia da linguagem em Giambattista Vico

São Paulo

2009 
UNIVERSIDADE DE SÃO PAULO

FACULDADE DE FILOSOFIA, LETRAS E CIÊNCIAS HUMANAS

DEPARTAMENTO DE FILOSOFIA

PROGRAMA DE PÓS-GRADUAÇÃO EM FILOSOFIA

\section{A arqueologia da linguagem em Giambattista Vico}

Antonio Sergio da Costa Nunes

Tese apresentada ao Programa de Pósgraduação em Filosofia Moderna do Departamento de Filosofia da Faculdade de Filosofia Letras e Ciências Humanas da Universidade de São Paulo, para a obtenção do título de Doutor em Filosofia.

Orientador: Profa. Dra. Maria das Graças de Souza

SÃO PAULO

2009 
Para Rute e minha filha Izadora com carinho. 
A minha mãe Iracy da Costa Nunes

Ao meu pai Audifax Muniz Nunes e minha tia-mãe Maria da Glória Muniz Nunes in memoriam 


\section{AGRADECIMENTOS}

Este trabalho teve o apoio institucional da Faculdade de Filosofia e do Instituto de Filosofia e Ciências Humanas da Universidade Federal do Pará, que concedeu a liberação integral das minhas atividades docentes no Campus do Guamá em Belém do Pará. A licença para o doutoramento foi possível graças ao apoio institucional da PróReitoria de Pesquisa e Pós-Graduação e da Faculdade de Filosofia da Universidade Federal do Pará. O apoio financeiro da CAPES - Fundação Coordenação de Aperfeiçoamento de Pessoal de Nível Superior - tornou viável esta pesquisa.

A Faculdade de Filosofia da Universidade de São Paulo tornou realidade este trabalho de doutoramento. Sou extremamente grato aos professores e funcionários do Programa de Pós-Graduação em Filosofia desta Instituição. Ressalto a receptividade da funcionária Maria Helena que sempre foi solícita em me atender.

Um grupo significativo de pessoas também veio contribuir com este trabalho desde a concepção até ao produto final: a tese escrita. Destaco aqui o amigo que contribuiu decisivamente para a consecução deste trabalho, trazendo-me vários exemplares da Itália das obras de Vico, bem como das Universidades de Roma, não medindo esforços para conseguir exemplares que não são mais editados. A este amicofratello Paolo Carlucci meu mais efusivo agradecimento. Meus agradecimentos a Ruth Benchimol pelo apoio e incentivo, ao Prof. Jacob Lebenstein pelas aulas de Latim e a correção gramatical da minha tese, à Comunidade Esmeraldina que me acolheu durante hum ano em que residi em São Paulo. A minha procuradora na UFPa Ana Dolores que sempre foi solícita as minhas necessidades acadêmicas e ao caro Honorino Carneiro que sempre me atendeu com boa vontade. 
Agradeço, também, aos primeiros contatos que fiz sobre meu Projeto de Pesquisa, ao Prof. Mario Porta da Pontifícia Universidade Católica de São Paulo que me sugeriu esse pensador, ao meu colega Prof. João Batista da Faculdade de Filosofia da Universidade Federal do Pará que travou as primeiras discussões acerca de Vico. A Profa. Maria de Nazaré Sarges que muito torceu e incentivou.

Algumas pessoas se destacaram na amizade e na contribuição efetiva para a redação desta tese. Sou muito grato ao Prof. Dr. Humberto Guido da Universidade Federal de Uberlândia, pelo empenho, a ajuda, os esclarecimentos e os comentários valiosos acerca deste trabalho durante o Exame de Qualificação, bem como da inestimável ajuda no fornecimento de vários textos importantíssimos para o desenvolvimento da tese. Agradeço de modo particular a Profa. Vilma De Katinszky que influenciou decisivamente no enfoque escolhido para o desenvolvimento da tese, bem como pelas lições proferidas em sua disciplina sobre Vico. Foi decerto uma interlocutora de gabarito. Agradeço também seus comentários pertinentes feitos durante o Exame de Qualificação. Eternamente grato sou a minha competentíssima Orientadora Profa. Maria das Graças de Souza que me acolheu vindo dos rincões do norte e me acompanhou atentamente e, com a serenidade que lhe é peculiar me conduziu com propriedade nas discussões e desenvolvimento deste trabalho em todo o seu percurso.

Por fim, agradeço ao Prof. Benedito Nunes, meu mestre desde a época da graduação na Universidade Federal do Pará que aceitou o convite para participar da Banca Examinadora e tem acompanhado esta trajetória, ao Prof. Franklin Leopoldo por sua valiosa participação, ao Prof. José Expedito Passos Lima, ao Prof. Valverde da PUC de São Paulo e a Profa. Constância meus sinceros agradecimentos. 


\section{RESUMO}

Este trabalho é resultado da pesquisa desenvolvida sobre a concepção do certum em Giambattista Vico. O nosso interesse foi encontrar nos diversos escritos filosóficos de G. Vico (1668-1744) um novo modo de apreensão da concepção original do pensador acerca do Conhecimento e de que modo ele apreendeu e trabalhou essa visão de mundo, ao contrário da visão tradicional, que atribuiu valor lógico ao modo de conhecer mediante o verdadeiro e o falso. Vico concebeu o conhecimento tanto como ordem do certum quanto como ordem do verum, realçando o papel originário do certum. Esse novo modo de perceber a ordem do certum confere ao saber viquiano uma lógica própria: a lógica do verossímil. A verossimilhança é trabalhada enquanto elemento que nos leva à certeza mediante a exclusão de toda exatidão matemática conferida ao conhecimento, nos propiciando a possibilidade de alcançá-lo na sua incerta abrangência e/ou nos seus incertos limites. 


\begin{abstract}
This work is the result of the research developed about the conception of the certum in Giambattista Vico. Our interest was to found, in the various philosophical writings of G. Vico (1668-1744), a new way of understanding the original conception of the thinker about knowledge and how he worked and seized this vision of the world, unlike the traditional view which gave a logical value to the way of knowing before the true and false. Vico conceived the knowledge both as certum and verum, highlighting the original role of certum. This new way of perceiving the order of certum gives to the Vico's knowing its own logic: the logic of credible. The credibility is treated like the element which leads us to the certainty before the exclusion of all mathematical accuracy given to knowledge in providing the possibility of reaching it in its uncertain scope and / or its uncertain boundaries.
\end{abstract}

PALAVRAS CHAVES

CERTEZA - VERDADE - LINGUAGEM - HISTÓRIA - IMAGINAÇÃO 


\section{LISTA DE ABREVIAÇÕES}

Or. I... VI

Orazioni inaugurali (1699-1707)

De rat. $\quad$ De ratione (1709)

De ant. De antiquissima (1710)

Sin. $\quad$ Sinopsi del Diritto universale (1720)

$\mathrm{Du} \quad$ Diritto universale (1720-1722)

Vita Autobiografia (1728)

De mente De mente heroica (1732)

Sn44 Scienza nuova (1744)

De const. De constantia (1721

PP.....................Proposição

FGP..................Forma Geral da Proposição

Ei...................Edizione Italiàna

Todas as traduções das obras de Vico foram feitas do italiano para o português pelo autor da tese, para qual utilizei Ciência Nova da Fundação Calouste Gulbenkian em paralelo com a versão italiana da Biblioteca Universale Rizzoli. As obras escritas em espanhol, elencadas nas Referências Bibliográficas, também foram traduzidas pelo autor. 


\section{SUMÁRIO}

Pág.

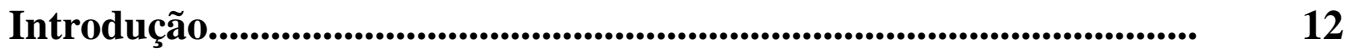

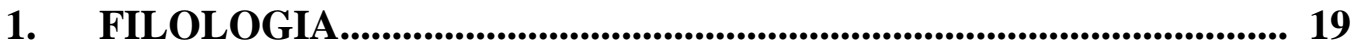

1.1. A crítica ao cartesianismo................................................................. 19

1.2. A linguagem mítica........................................................................................... 25

1.2.1. A epistemologia da Scienza Nuova ................................................ 35

1.2.2. Filosofia e Filologia na trama da obscuridade........................................ 42

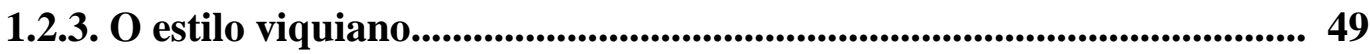

1.3. A natureza da filologia........................................................................5 58

1.3.1. Homero e a cientificidade da Filologia........................................... 66

1.3.2. $\mathrm{O}$ corpo e $\mathrm{o}$ canto.......................................................................................... 72

2. A ESTRUTURA CONCEITUAL_..................................................79

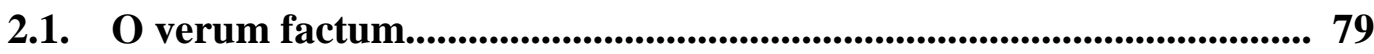

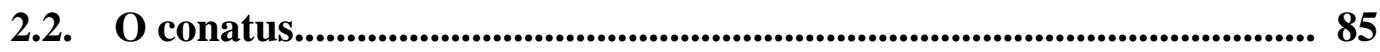

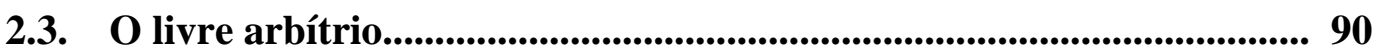

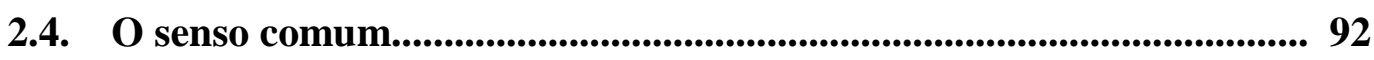

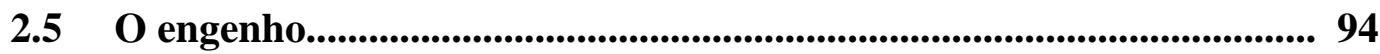

2.4.1. O processo de significação.................................................................... 97

2.4.2. A poeticidade mítica...........................................................................................103

2.5. Da passagem da Idade dos deuses a Idade dos heróis...............................108

3. A FACULDADE DA IMAGINAÇÃO ........................................120

3.1. A formação da mente poética.........................................................120 
3.2. A concepção racionalista e a imaginação...........................................123

3.2.1. Linguagem e imagem: dedução e indução.........................................127

3.2.2. A criação fantástica......................................................................................133

3.3. O princípio de identidade fantástica................................................141

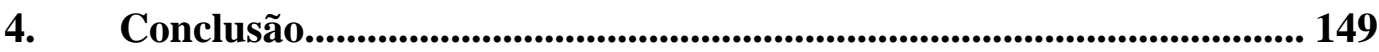

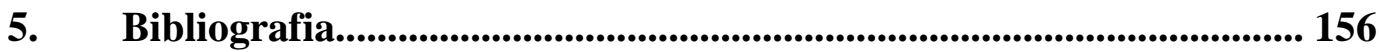




\section{INTRODUÇÃO}

Esta tese tem o propósito de demonstrar a cientificidade e a natureza constitutiva da doutrina filológica empregada por Vico na sua Scienza nuova ${ }^{1}$ (1744) através do confronto entre o método indutivo / intuitivo peculiar à ordem do certum $^{2}$, e o método dedutivo peculiar à ordem do verum e, a partir daí, recortar a concepção viquiana caracterizada pela apreensão do mundo mediante a ordem do certum, isto é, como modo de leitura ou interpretação que ele realiza para investigar a gênese da linguagem mito-poética, bem como demonstrar a pertinência que a linguagem poética presta à ciência por meio da Imaginação.

Para alcançarmos este objetivo, foi necessário refletir sobre a cientificidade da doutrina filológica: a ausência ${ }^{3}$ enquanto origem da linguagem como elemento necessário do indeterminado, o confronto entre os métodos indutivo e dedutivo como indício de ausência de mensurabilidade e o conhecimento fantástico como elemento primeiro de apreensão da realidade peculiar ao senso comum.

Considerando os momentos da reflexão, dividimos o trabalho em três capítulos essenciais, com suas respectivas subdivisões para garantir a dinamicidade textual: $01^{\circ}$ capítulo versa sobre o estatuto particular da doutrina filológica, mais especificamente o método de investigação do conhecimento mediante seu caráter verossimilhante; o $2^{\circ}$ capítulo analisa a concepção do certum em Vico em confronto com a concepção do verum a partir dos conceitos fundamentais da Scienza Nuova, seguindo o modelo redacional apresentado em sua De antiquissima ${ }^{4}$, e o $3^{\circ}$ capítulo versa sobre a Imaginação ou Fantasia enquanto faculdade do entendimento com a qual se chega à racionalidade.

\footnotetext{
${ }^{1}$ Citação abreviada da obra viquiana, Scienza Nuova 1744 (Sn44).

${ }^{2} \mathrm{O}$ conceito de certum e verum desenvolveremos no capítulo I

${ }^{3} \mathrm{O}$ conceito de ausência advém do estruturalismo como veremos no capítulo 2, tp. 2.6.1., cit. 162, p. 108.

${ }^{44}$ Nesse $3^{\circ}$ cap. inserimos a forma elaborada por Vico em seu Libro Primo ossia Metafisico [Cf. De Antiquissima Italorum Sapientia, L'Antiquissima Soienza Degli Italici, 1710, Opere Filosofiche, intriduzione di Nicola Badaloni, testi, versioni e note a cura di Paolo Cristofolini,Sansoni Editore, Firenze, 1971]. Talvez para alguns tenha a forma de um glossário, embora não o seja.
} 
Decerto, encontraremos ao longo dos três capítulos recorrências textuais necessárias, pertinentes ao arcabouço conceitual viquiano que freqüentemente comparecem como remissões para enfoques diferentes. Essas recorrências, marca indelével presente na Scienza nuova, são traços do próprio tempo viquiano impressos no texto em movimento espiralar, numa ida e vinda constante, imprimindo um processo que, valendo-se dos conceitos corsi e ricorsi ${ }^{5}$ transpõe para o texto como acorde retórico que soa entre parágrafos, pausas e pontos.

Por isso, o comentário das obras de Giambattista Vico requer certa mudança de atitude, mudança não propriamente comportamental, mas mudança de valores, de concepção, de visão de mundo; ou melhor dizendo, aquilo que os gregos denominaram de $\mu \varepsilon \tau \alpha \beta \alpha \dot{\alpha} \lambda \lambda \omega$, transformar, mudar, converter, modificar, alterar, ou mais propriamente, $\mu \varepsilon \tau \alpha \beta \dot{\alpha} \lambda \lambda \omega \gamma \nu \omega ́ \mu \eta$, mudar de opinião, ou ainda, mudar de concepção. No entanto, esta mudança necessita sem dúvida alguma de certa dose de ousadia, isto é, de romper com determinados conceitos, romper com determinados pré-conceitos e romper com determinadas visões equivocadas de autores reconhecidos, bem como romper com uma viciosa visão sedimentada secularmente na cultura filosófica, desde os socráticos até ao cartesianismo.

Tal atitude sem dúvida gera angústias e inseguranças, porém à medida que se avança nas descobertas de novos fatores e variáveis que confirmam e sustentam as idéias, pareceres e avaliações novas e inusitadas acerca do pensamento de um autor como Vico nos trazem satisfação e convicção do caminho percorrido e das sendas descobertas.

A fidelidade ao pensamento de Vico requer, sem dúvida, assumir sua concepção com base nos conceitos que lhes são fundamentais: os universais fantásticos, a ordem do certum, a metafísica e lógica poéticas, bem como a percepção da sutil operação que ele realiza na feitura da própria obra ( $\mathrm{Sn} 44)$, aonde se expressa como veremos nos capítulos desta tese a forma recorrente impressa nos seus capítulos, nos seus parágrafos, nos seus tópicos, como acima já declaramos; as

\footnotetext{
${ }^{5}$ Curso e retorno (corsi e ricorsi) são conceitos que se referem ao movimento da história, que não se dá de forma retilínea, mas simultânea em graus diferentes e diversos e, que se expressa também no próprio estilo textual viquiano que se processa em várias frentes como remissividade, repetências e avanços
} 
analogias apresentadas entre fatos históricos e mitos, as fábulas como elementos de provas filológicas destinadas a garantir o fundamento das suas investigações e a exaustiva análise da linguagem e dos falares na era dos deuses e dos heróis.

Creio que só a partir dessa mudança de opinião/concepção e dessa assunção conceitual, poderemos de fato resgatar o autêntico Vico que foi desqualificado por muitos e por tantos incompreendido. Somente assim poderemos reconhecer o seu mérito e a genialidade do seu pensamento.

É perceptível nos seus escritos a grande necessidade em confrontar o cartesianismo em conformidade com o humanismo em voga, e insistir com inelutável veemência na demonstração de sua obra maior, a Scienza nuova. Como veremos no decorrer desta tese, trata-se do confronto entre o verum cartesiano e o certum viquiano.

Ao demarcar de forma absolutamente necessária a sua concepção humanista, percebemos o embate pulsante e ardente de suas idéias contra o cartesianismo nas diversas Orazioni inaugurales (1699-1707), em especial a defesa da topica sensibile (1709) na educação dos adolescentes e a função da vis veri ou vis rationi como elemento presente nos sentidos. Sente-se nos seus escritos o fervor do embate, não somente enquanto duelo conceitual, mas também ideológico e político, manifestando claramente a grande contenda havida entre italianos e franceses na sua época.

No Liber metaphisicus (1710) está a defesa da limitação do conhecimento matemático que não poderia impor-se como verdade absoluta a todas as ciências, o ponto metafísico como causa da extensão e portanto da existência, bem como a fantasia, diria, maior de seus feitos, enquanto faculdade que forma as imagens das coisas que mediada pela mente nos permite vivenciar ${ }^{6}$ o que fazemos. No De antiquissima italorum sapientia (1710) Vico desenvolve a sabedoria latina para desvendar a sabedoria dos primeiros italianos, bem como o animus e anima e o vitalismo deles

\footnotetext{
${ }^{6}$ Empreguei o conceito de vivência por conter maior abrangência que o conceito de experiência, pois envolve uma inter-relação do homem com o meio e entre si, como veremos nos capítulos precedentes.
} 
procedentes, e no De ratione estabelece o confronto com a física cartesiana, assim como no $D e$ constantia iurisprudentiae e De antiquissima, em que discorre acerca de vários conceitos como o verum factum (conhecer e fazer), o conatus (conato), as loci (tópicas), o sensu comunis (senso comum), o liberum arbitrium (livre arbítrio), a auctoritas (autoridade), o ingenium (engenho) etc., os quais terão acabamento final na Scienza nuova 44. Não poderíamos deixar de citar o De uno, em que ele discorre acerca dos princípios metafísicos do direito e da jurisprudência.

Mas o que nos causa maior decepção é o fato de Vico ter sido olvidado durante muitos e muitos anos em sua própria terra, a começar pelo vil tratamento que lhe foi dado em vida, conforme nos afiança em sua Autobiografia (1728).

É com grande pesar, sem dúvida, que este reconhecimento seja tardio, e por isso mesmo temos que levar em consideração as suas influências nas Ciências Humanas, em particular na História e na Ciência do Direito. A Ciência da História foi por ele inaugurada com o auxílio da doutrina filológica, constituída através do seu método como instrumento científico para o resgate da origem da história, por conseguinte da origem da linguagem; aqui reside a grande descoberta viquiana, resultante de sua inusitada e originalíssima concepção mediante a ordem do certum, como reação à destruição com golpes de lógica cartesiana, do mito adâmico e da veracidade da história mosaica.

Por quê classificamos a sua concepção de certum? Que relação teria essa concepção com a doutrina filológica? E quais as consequiências científicas dessa relação para a realização de uma investigação da linguagem na era dos deuses e heróis? Essas questões definem e contemplam o que nesta tese desenvolvemos ao recortarmos as questões teóricas e epistêmicas da sua concepção para marcarmos a estrutura componente de sua tese, de sua visão de mundo, de sua teoria do conhecimento, minimizando, portanto, a relação correspondente aos fatos históricos ${ }^{7}$.

\footnotetext{
${ }^{7}$ Ao minimizarmos a correspondência entre a teoria viquiana e os fatos históricos, pretendemos realçar a sua base epistêmica, objeto desta investigação.
} 
A primeira impressão inovadora que percebemos no pensamento viquiano foi o seu modo diverso de pensar as coisas, queremos dizer, a linguagem, a fantasia, a história, os bestiones ${ }^{8}$, o mito e o arranjo conceitual originalíssimo que ele trama e tece, imprimindo-lhe a marca do verossímil. Decerto, o que nos levou a esta inferência foram as considerações traçadas por Croce, Nicolini, Badaloni, Rossi e Berlin entre outros, que se detiveram nas "contradições teóricas", bem como na repetição que se tornou um clichê na quase totalidade dos especialistas e daqueles que de um modo ou outro trabalham o pensamento viquiano e insistem na "obscuridade do seu pensamento", por conseqüência, de sua obra. Considerações essas que parecem completamente equivocadas porque partem de pressupostos e premissas estritamente racionalistas mediante a ordem do verum, por isso completamente desfocadas. Mesmo que se encontrem em Vico alguns equívocos de ordem historiográfica ou de referências equivocadas, próprias de sua época, bem como se encontrem formas inovadoras de análise filológica por ele desenvolvida em função de seu trabalho investigativo, em nada tais equívocos desqualificam sua teoria, por serem simplesmente irrelevantes para o propósito a que se dispôs, enquanto suas análises filológicas testemunham o mérito e a eficácia de seu método, posto que os seus argumentos norteiam-se sempre por pressupostos e premissas na ordem do certum.

Mas, afinal, por que frisamos a concepção do certum? Não podemos falar dessa concepção sem falar necessariamente da natureza constitutiva da filologia.

O grande mérito de Vico foi questionar de forma eficiente e nos parece irônica, ao utilizar a dúvida para por em xeque o Cogito cartesiano que parte de uma certeza para chegar a uma verdade. Ora, a certeza enquanto certum define a ordem do pensamento verossimilhante, que é incerto, indeterminado ou ainda provável, próprio de um raciocínio indutivo; a verdade enquanto verum define o pensamento exato, determinado, mensurável, verdadeiro ou falso, próprio de um raciocínio dedutivo, conforme discorreremos ao confrontar a lógica da filologia com a lógica da

\footnotetext{
${ }^{8}$ Mantivemos no original italiano utilizado por Vico.
} 
ciência contemporânea, em especial a do positivismo lógico no primeiro e terceiro capítulos desta tese.

A filologia é uma ciência que também investiga a origem da linguagem, e esta se apresenta como ausência própria dos tempos obscuros, posto que o sinal, ou o nome, ou ainda a palavra, compõe-se necessariamente de interstícios entre signos, os quais se constituem do nada, isto é, de uma ausência, de uma pausa, de uma fenda, ou ainda do silêncio, elemento que une e reúne de forma inexorável os signos entre si. Esta ausência remete-nos do ponto de vista mítico, a um passado remoto, disperso e obscuro que somente e tão somente o verossimilhante é capaz de resgatar, por meio da análise filológica minuciosa, levando em consideração a etimologia, a hermenêutica e a história através de alguns dados como a epigrafia, a numismática e a cronologia que não fornecem resultados exatos, mas indicam possibilidades que somente o método filológico com base na concepção do certum pode confirmar, pois somente o certum pode incidir sobre a ausência.

Procuramos nesta tese pontuar a relação da lógica filológica com a lógica da ciência contemporânea, desenvolvendo um permanente confronto entre ambas na tentativa de elucidar as questões pertinentes à cientificidade filológica e à inópia da racionalidade mensurável.

A filosofia comporta a ordem do verum, pois ela prima pelo rigor dos conceitos, pela mensurabilidade das proposições e pela logicidade de suas implicações quanto ao valor de verdade, porque é essencialmente racionalista.

Vico relaciona esses dois campos do saber para desenvolver suas teses: esta que lhe permite explicitar os argumentos, iluminando os conceitos que se articulam para dar veracidade às suas conclusões e aquela que apresenta as provas justificantes de seus questionamentos e investigações.

A relação existente entre a ordem do certum e a doutrina filológica encerra a própria visão de mundo concebida por Vico e por ele trabalhada em função de suas pesquisas. Aqui reside a 
grande dificuldade que muitos comentadores manifestam ao tentarem interpretá-lo com o viés do verum, não atentando de forma mais precisa para esse enfoque peculiar viquiano, a partir do qual se dá uma nova via de conjugação de conceitos que ele utilizou e remodelou para viabilizar a compreensão e a funcionalidade textual de suas articulações argumentativas e inferências verossímeis.

As conseqüências desse novo modo de fazer e pensar a ciência tem o mérito de revelar a autenticidade do pensamento mítico, de resgatar a origem da linguagem e de descobrir o verdadeiro Homero, bem como promover a primeira ciência absolutamente humana, a História, na qual o papel principal é exercido pelo homem que não parte de elementos supostos para dar veracidade aos fatos, mas parte da sua própria ação para realizá-los e conhecê-los, desenvolvendo, portanto, uma ciência real. Vico torna-se assim um dos maiores humanistas.

Desse modo desenvolve a sua Scienza nuova, recorrendo ao método por ele renovado e vivenciado mediante a phantasia reminiscente enquanto "memória dilatada e composta", que permitiu o resgate da origem da linguagem desde os primórdios da idade dos deuses e da idade dos heróis mediante a cultura latina sapientemente cultivada e decantada por sua habilidade e destreza retórica, filológica e histórica, professado na consecução de sua obra, que foi deveras fruto de sua percuciente "curiosidade, que é filha da ignorância e mãe da ciência" sapienza volgare ou riposta ${ }^{11}$.

Sem dúvida, a sentença de Marco Crasso cabe com engenhosa maestria ao grande empreendimento de Giambattista Vico:

"Fremant omnes: dicam quod sentio",12

\footnotetext{
${ }^{9}$ Vico, Ciência Nova, [Cf., Secção Segunda, Dos Elementos, L, § 211, p.134, Tradução de Jorge Vaz de Carvalho, Prefácio de António M. Barbosa de Melo, Fundação Calouste Gulbenkian, Lisboa, 2005; Vico, Giambattista, La Scienza Nuova, Edizione Italiàna [Cf., Libro Primo, Degli Elementi, L, p. 198, introduzione e note di Paolo Rossi, BUR (Biblioteca Universale Rizzoli), nona edizione: dicembre 2004, Milano] .

${ }^{10}$ Ibidem, [Cf., Secção Segunda, Dos Elementos, tp. XXXIX, § 185, p.126; Ei, p. 193] .

${ }^{11}$ Ibidem, [Cf., Secção Segunda, Dos Elementos,tp. XCII, § 284, p.154; Ei, p. 214].

12 "Tremam todos: direi o que sinto"
} 


\section{CAPÍTULO I}

\section{FILOLOGIA}

\subsection{A Crítica ao cartesianismo}

Com o advento da era moderna, a questão do conhecimento na Europa do século XVII passou por profundas transformações e adquiriu novos paradigmas: o homem regula-se pela unidade e segundo a ordem da razão, e os fenômenos da natureza passam a ser mensurados pelas rígidas regras do mecanicismo.

Descartes introduziu um novo modo de fazer ciência com o seu método analítico, estabelecendo mais rigor na aquisição do conhecimento científico. Partindo da dúvida metódica mediante a intuição direta do espírito, a verdade do conhecimento dar-se-ia através de uma evidência imediata, havendo necessidade de decompor todas as questões em seus elementos últimos e mais simples, e de reconstruí-las a fim de serem comprováveis em sua evidência originária, simples e indubitável através de uma proposição apodítica que contivesse uma verdade crível por si mesma. A dúvida metódica põe em suspensão os juízos acerca da aparência do mundo sensível, da essência, da existência, como também das próprias verdades matemáticas ${ }^{13}$. O desenvolvimento do método de duvidar se faz pelas cadeias dedutivas até atingir um núcleo irredutível, o Cogito ergo sum (penso, logo existo), que se torna desse modo uma evidência primária, a idéia clara e distinta por antonomásia ${ }^{14}$, cujo interesse maior foi fundamentar a ciência natural e estabelecer uma nova ordem de pensamento que superasse o modelo escolástico.

\footnotetext{
${ }^{13}$ Cf. Descartes, Meditações, [Cf. Meditação Terceira, De Deus; que Ele existe, §4, p.100, J.Guinsbug, B.P. Júnior].

${ }^{14}$ Observamos que Descartes lançou mão de um conceito puramente antonomástico, que provém dos caracteres poéticos e o objetiva mediante a suspensão de juízo, tornando-o uma res cogitans. Há, nessa
} 
Com Galileu Galilei a ciência passou a desempenhar um papel decisivo na história do pensamento europeu, pois recolocou os problemas capitais da teoria científica, da filosofia da ciência e da epistemologia. A investigação natural não consistiria numa simples recompilação de dados sensíveis, mas numa certa ordenação deles pela razão matemática, como afirma no Il Saggiatore :

"A filosofia está escrita neste grandíosíssimo livro que continuamente está aberto diante de nossos olhos (digo o universo), mas não se pode entendê-lo sem antes procurar entender sua língua e conhecer os seus caracteres nos quais está escrito. Esse livro está escrito em língua matemática e seus caracteres são triângulos, círculos, outras figuras geométricas, sem as quais é totalmente impossível entender humanamente uma palavra, e sem as quais nos agitamos em vão em um obscuro labirinto" ${ }^{, 15}$.

Toda consideração quantitativa em que o mensurável é a base de todos os fenômenos, cujo processo se dá pela decomposição dos elementos simples e mensuráveis, seria relativo às noções como a causalidade e simplicidade do acontecer natural. O seu método é ao mesmo tempo indutivo e dedutivo; aquele reduz o fenômeno a uma fórmula matemática, e este deduz da lei geral os próprios fatos nela contidos. ${ }^{16}$

Esse é o panorama que situa de modo claro, o percurso da ciência no século XVII, tendo como arcabouço o renascimento de novas concepções que têm como base os princípios do

\footnotetext{
recognição, uma viragem fantástica de fecunda criação, no entanto, restrita e insipiente pela analiticidade geométrica que pretendeu absolutizar o conhecimento sem levar em consideração o princípio antonomástico que deriva da ordem do certum.como se pode verificar no De ant.[Libro Primo ossia Metafisico, cap. III, p. 70-74, P. Cristofolini] e nas Meditações [Meditação Segunda, Da natureza do espírito humano; e de como ele é mais fácil de conhecer do que o corpo, § 4, p. 91-92, J.Guinsburg, B.P. Júnior].

${ }^{15}$ Galileu, Os Pensadores [Cf. Galileu, Vida e Obra, O Ensaiador, p. 119, Traduções de Helda Barraco, Nestor Deola e Aristides Lôbo, Ed. Abril S.A. Cultural, São Paulo, $3^{a}$ edição, 1983].

${ }^{16}$ Este princípio cartesiano se mantém até hoje na lógica matemática como observaremos no positivismo lógico desenvolvido por Wittgenstein no seu Tractatus Logico-Philosoficus. [Cf. cap. III, Tópico 3.2, A concepção racionalista e a imaginação, p. 85, desta tese],
} 
platonismo que ressurgem em detrimento da escolástica, prenunciando o seu ocaso, abrangendo desde os finais do séc.XIV ao começo do séc.XVII..

As críticas feitas ao Cogito cartesiano foram, decerto, decisivas para colocar em dúvida a doutrina de Descartes, embora Vico tenha pago um preço elevadíssimo, como se pode observar em sua Autobiografia. Isolado e sem qualquer mérito, foi de certo modo desqualificado ao pretender refutar a doutrina cartesiana em várias frentes, da educação à ciência. No entanto, manteve-se firme e determinado em sua missão, desenvolvendo com maestria a composição de sua obra maior, a Scienza Nuova. Seguindo com destreza e ordem a logicidade da estrutura e dos argumentos, combinou a filosofia com a filologia, a fim de dar cientificidade à sua doutrina, como também estabeleceu a lógica e a metafísica poéticas e desvendou a concepção mítica que cercava a Ilíada e a Odisséia de Homero. O mito reinterpretado e apreendido na sua simbologia manifesta-se enquanto história dos povos primigênios que deu origem a nossa história.

Ao resgatar a história do mito, Vico pretende demonstrar que essa concepção não foi meramente um legado fantasioso e superficial. Pelo contrário, demonstra a originalidade que essa concepção contém, retratando uma era em que o homem manifestava robustíssimas paixões, instintos primitivos, dando expressão às imagens do mundo, como o céu, a tempestade, o raio, o sol, a lua, as estrelas, as árvores, o vale, a fonte, a gruta, os animais, as feras etc ... e tudo o que esse homem absorvia, e com a natureza convivia mediante uivos, cantos, assobios e gesticulações. A originária manifestação da linguagem muda,

“na qual um momento ativo do real se fixa num gesto que é um 'retrato': ainda traduzido sobre a matéria, um hieróglifo... Quando o gesto transmuta-se em som para representar aquele conteúdo, reproduzirá aquele momento da realidade dinâmica... "17,

\footnotetext{
17 Pagliaro, Antonio, [Cf. Giambattista Vico tra linguistica e retorica, Giambattista Vico nel terzo centenario della nascita, Edizioni Schientifiche Italiane, p.143, 1968].
} 
em que os primeiros homens passarão a nomear e promoverão as primeiras distinções em relação às coisas e aos fenômenos de forma sensitiva e fantástica.

O pensamento moderno pulsante pelo rompimento com a escolástica e vivificado pelo Renascimento não impediu o furor humanístico do pensamento viquiano que estabeleceu a equivalência entre o homem e Deus através da teoria do verum factum, bem como percebeu o dilema da res cogitans e da mathesis universalis ou more geometrico cartesiana, cuja verdade foi derivada do certum numa clara contradição, já que pela certeza Descartes chegou a verdade evidente. O verum e o certum confundem-se:

“Um outro é pensar; e verifico aqui que o pensamento é um atributo que me pertence; só ele não pode ser separado de mim. Eu sou, eu existo: isto é certo...Nada admito agora que não seja necessariamente verdadeiro: nada sou, pois, falando precisamente, senão uma coisa que pensa, isto é, um espírito, um entendimento ou uma razão, que são termos cuja significação me era anteriormente descinhecida. Ora, eu sou uma coisa verdadeira e verdadeiramente existente; mas que coisa? Jáo disse: uma coisa que pensa. E que mais? Excitarei ainda minha imaginação para procurar saber se não sou algo mais. E mesmo esses termos fingir e imaginar advertem-me de meu erro; pois eu fingiria efetivamente se imaginasse ser alguma coisa, posto que imaginar nada mais é do que contemplar a figura ou a imagem de uma coisa corporal... Haverá algo em tudo isso que não seja tão verdadeiro quanto é certo que sou e que existo...embora, com efeito, seja uma coisa bastante estranha que coisas que considero duvidosas e distantes sejam mais claras e mais facilmente conhecidas por mim do que aquelas que são verdadeiras e certas e que pertencem a minha própria natureza"18

\footnotetext{
${ }^{18}$ Descartes, Meditações, [Cf. Meditação Segunda, Da natureza do espírito humano; e de como ele é mais fácil de conhecer do que o corpo, § 7,9,10, p. 93-96], Os Pensadores, Ed. Victor Civita, $3^{\text {a }}$ edição, São Paulo, 1983. As palavras em negrito foram destacadas pelo autor desta tese.
} 
Vamos encontrar também no Discurso do Método acerca da diversidade de concepções filosóficas, a presunção de Descartes em considerar que entre essa multiplicidade de opiniões, haveria de ter uma verdadeira, pois que essa multiplicidade resultaria "quase como falso, tudo quanto era somente verossímil ${ }^{19,}$, mesmo que sua afirmação seja dúbia.

Enquanto Vico no De Uno estabelece claramente essa distinção, como podemos observar, demonstrando a contradição cartesiana:

"Temos dois vocábulos: verum e certum, dos quais distinguimos os diversos significados, assim como todos distinguem o falso do dúbio; por isso, tanto se afasta o falso do dúbio, quanto o certum do verum. Se estas duas coisas não fossem diversas e distintas, não conseguiríamos, que muitas coisas verdadeiras mostrando-se talvez dúbias, seriam por sua vez dúbias e certas, assim como, muitíssimas coisas falsas pudessem se ter por certas, assim seriam simultaneamente falsas $e$ verdadeiras.

O verum nasce da conformidade da mente com a ordem da coisa, e o certum é produto da consciência assegurada pela dúvida. Apela-se à razão da conformação com a ordem da coisa; por isto, se é eterna a ordem da coisa, é eterna a razão da qual se apresenta a eterna verdade; se a ordem da coisa contemplada é de tal natureza que não subsiste em todo o tempo, em todo o lugar e por tudo, não haverá somente uma razão provável nas coisas que esperam pela ordem cognitiva, nem por uma razão verossímil naquela que realizemos uma operação. Assim como o verum é essência da razão, assim será elemento intrínseco do certum a autoridade, tanto aquela sugerida por nosso próprio sentido que chama-se auctoritas, quanto aquela imposta pelos outros, os quais denominaram autoridade, nascendo ambos da persuasão ${ }^{, 20}$.

19 _ Discurso do Método, [Cf., Primeira Parte, p. 32, Os Pensadores, Editora Abril, $3^{\mathrm{a}}$ edição, 1983].

20----, Opere Giuridiche, [Cf. De Uno, Proloquio Dell'Opera, Definizioni Del vero e Del certo, pg. 34,Sansoni Editore, Firenze, 1974]. 
Feito este percurso para esclarecer a controvérsia entre Vico e o cartesianismo, percebe-se a obstinação viquiana para definir a Imaginação enquanto faculdade possível de análise, já que envolve toda a rede que compõe o pensamento mítico, através da ordem do certum, pois esta não lhe provocaria distorções, sendo, por isso, elemento fundamental na sua Scienza nuova.

“...os primeiros povos da gentilidade, por uma demonstrada necessidade de natureza, foram poetas e falaram por caracteres poéticos; esta descoberta, que é a chave mestra desta Ciência, custou-nos a pesquisa obstinada de quase toda a nossa vida literária... "21.

Tais caracteres poéticos se originam na Imaginação, faculdade percebida por Vico como eixo para o desenvolvimento do conhecimento, a matriz, digamos assim, que vai proporcionar ao homem agir, criar e conhecer, sem a qual não seria possível o desenvolvimento da racionalidade.

O elemento basilar da Scienza nuova44 definido por Vico é justamente o fato de que os primeiros autores do mundo civil foram poetas. Isto implica dizer que os primeiros homens expressaram-se mediante caracteres poéticos. Enquanto Vico considerou na história da humanidade a importância de tal linguagem, muitos a desprezaram por não conter os elementos que a mathesis universalis requeria para torná-la compreensível. Por isso o cartesianismo relegou a concepção mítica como algo sem sentido, e a fantasia enquanto faculdade fora desqualificada porque seria incapaz de proporcionar conhecimentos verdadeiros.

Sendo o mito fruto da imaginação não faria parte da história, e portanto, não existiria enquanto fato. Para Descartes,

“Quando a nossa alma se aplica a imaginar alguma coisa que não existe..., e precedam apenas de que, sendo os espíritos diversamente agitados, e encontrando os traços de diversas

\footnotetext{
${ }^{21}$ Ibidem, [Cf. Ideia da Obra, Explicação da pintura preposta no frontispício que serve para a introdução da obra, § 34, p. 37; Ei, p. 114].
} 
impressões que precederam no cérebro, tomem aí seu curso fortuitamente por certos poros mais do que por outros. Tais são as ilusões de nossos sonhos e também os devaneios a que nos entregamos muitas vezes estando despertos, quando nosso pensamento erra negligentemente sem se aplicar por si mesmo a nada ${ }^{22 \%}$.

Para os povos primigênios tal linguagem foi uma necessidade natural de se fazerem entender, pois essa linguagem poética não era apenas um produto da mente, mas também uma lógica que proporcionou o desenvolvimento mental dos homens primigênios nos tempos bárbaros. Não sendo, portanto, a poesia um mero ornamento. A natureza da poesia e do mito não foi simples ornamento nos tempos poéticos, mas resultado de uma lógica que opera transferindo significados que lhes são familiares ao que é percebido.

Essa transferência de significados da linguagem figurativa constituiu uma operação da mente que permitiu ao homem primigênio criar o mundo das nações e constituir-se enquanto ser humano. O homem, graças à linguagem mítica e não ao raciocínio abstrato, diferencia-se da natureza sem dela distanciar-se. Essa linguagem, carente de conceitos abstratos e eminentemente poética, característica essencial do mito, não era apenas simples documentação histórica, mas a linguagem em que os povos primigênios expressavam suas próprias idéias, como veremos em seguida.

${ }^{22}$ Descartes, [Cf., As paixões da alma, Art. 20-21, Os Pensadores, Editora Abril, p. 224-225, $3^{\text {a }}$ edição, 1983]. Para Descartes a Imaginação voluntária, desde que não seja direcionada pela percepção do que existe, não passa de quimera, algo que não existe. 


\subsection{A Linguagem mítica}

Vico identificou três tipos de linguagem que correspondem às três idades da história : linguagem divina, heróica e humana ${ }^{23}$, sendo as duas primeiras poéticas e a terceira vulgar. Cada linguagem consta por sua vez de signos acústicos ( cantos, versos e linguagem falada) e visíveis (gestos, hieróglifos, insígnias, emblemas e escrita alfabética), compondo a essência dos mitos enquanto caracteres poéticos, e estes, enquanto signos de uma linguagem, correspondem à diversificação dos deuses que é a diversificação dos signos necessários num processo complexo da vida social e da experiência humana.

A doutrina mitológica viquiana propõe-se a reconstruir o vocabulário e a sintaxe, e, a partir destes, o mundo humano que resultou do processo da linguagem mítica. Por isso, Vico postulou a necessidade metodológica de um "dicionário mental comum" entre os povos, que permitiu verificar os pontos de contato, as inter-recorrências assemelhadas como deuses, temáticas (agrícola, pastoril), fábulas e provérbios encontrados em todas as nações, nascidos da experiência ou pela observação que se fazia sobre as coisas. Podemos considerar que os Universais Fantásticos viquianos são frutos da indigência de palavras, provindos de características mentais da espécie, presentes no senso comum, cuja capacidade, proveniente da mente primigênia através do conatus (força/potência, própria da vontade humana para refrear as paixões, é efeito da liberdade do arbítrio humano que permite direcionar essa vontade de forma positiva para fins de utilidade, fins que tragam benefícios ao homem $)^{24}$ que proporcionou o conhecimento mediante a percepção sensorial, estabelecendo determinadas relações das partes do corpo com os fenômenos naturais. Por isso a idéia de

\footnotetext{
${ }^{23}$ Destaque em negrito.

${ }^{24}$ Enquanto potência, o conatus é o indefinido processo motriz que gera o movimento, processo este gerado por uma mente infinita e em si imutável: Deus. [Cf. Vico, Ciência Nova, Secção Quarta, Do método, § 340, p. 181; De ant., cap’. IV, § III, Non vi è conato nei corpi estesi, p. 96].
} 
considerar a evolução da linguagem, análoga ao desenvolvimento dos órgãos do corpo humano, como natural e verossímil.

Eis por que o "dicionário mental comum" viquiano, enquanto condição proveniente de um estado natural que nasce do canto e da voz, é característica de todas as linguagens humanas, não por mero acaso, mas por necessidade, pois é com o corpo que o homem começa a elaborar a própria consciência da realidade para construir o próprio sistema de comunicação e da linguagem e, assim, organizar um tipo de saber para humanamente viver e agir, portanto, comum a todos os povos. Essa capacidade proviria da divina onomathesia, a linguagem comum a todos os homens por ação da divina providência. $\mathrm{O}$ homem degenerado pelo pecado original provocou a confusão das línguas e, conseqüentemente, promoveu a diversidade das línguas. Essa confusão babélica originou-se pela lenta degeneração da humanidade depois do dilúvio universal, pela qual a racionalidade íntegra se obliterou e se distorceu na desordem dos sentidos, necessitando o homem de manifestar através da realidade natural a sua vontade. Esta foi a razão pela qual os homens sentiram a necessidade de comunicar entre si essa nova experiência ao recuperar as idéias mediante a consciência emocional que se configurou na transposição fantástico-mítica ${ }^{25}$. Esta realidade natural por sua diversidade promoveu a diversidade das línguas, por conseguinte a diversidade dos povos, caracterizando-se pela diferença, em diferentes tempos e diferentes espaços do globo terrestre.

\footnotetext{
${ }^{25}$ Acerca do Dicionário mental comum que se apresenta em todas as línguas na particularidade dos povos, Angela Isoldi nos diz: "A criatividade do espírito humano se dá nesta síntese, e a poesis fantástica se coloca apropriadamente como testemunho da sinteticidade, na consciência dos sentidos e racionalidade. A experiência fantástico-emocional do mito é experiência do intelecto, e pode ser considerada pelo intelecto como um momento grosseiro e passional, enquanto na complexidade, na indistinção da consciência mítica é uma particular espontaneidade emocional, poética, que, embora lhe atribua uma excepcional força criativa lhe impede a possibilidade de entender e de definir a verdade da qual é portadora. A realidade fantástico-mítica, pela inadequação entre isto que é e aquilo que se crer ser, determina a exigência de um processo de explicação que realize a adequação. Tal processo não pode atuar se não como explicação do universal implícito no particular, e que se realiza através da atividade intelectual, que porém deve ser vivificada por um contínuo empenho a manter no universal aquela essencial abertura sobre o particular que esse revela na realidade concreta da consciência. Na consciência mítica está entre a falsidade do conteúdo e a verdade da idéia um natural equilíbrio garantido pela espontaneidade dessa realidade espiritual". [Cf., G.B.Vico, La vita e Le opere, Cappelli, 1986].
} 
“...pela diversidade dos climas, surgiram com diferentes naturezas, donde surgiram tantos diferentes costumes, assim, das suas diferentes naturezas e costumes nasceram outras tantas línguas diferentes; de modo que, pelas mesmas diversidades das suas naturezas, assim como observaram as mesmas utilidades ou necessidades da vida humana com aspectos diversos, donde surgiram tantos costumes das nações, geralmente diferentes e, por vezes, contrários entre si, assim, e não de outro modo, surgiram muitas línguas e tão diferentes quanto eles são „26

Os primeiros infantes vivenciaram fenômenos que lhes eram imediatamente dados, e com estes interagiam ativa ou passivamente. Imersos neles expressavam-se mediante caracteres poéticos gerados por suas fantasias, pois as vivências repetidas não foram esquecidas rapidamente, embora a sua elaboração tenha sido um longo processo de originária fixação.

A Scienza nuova parte da história mitológica que constitui as fábulas dos povos primigênios se fazendo linguagem, permitindo referir-se às suas necessidades e utilidades comuns. Vico mostra que cada elemento dessa linguagem representa elementos do mundo das nações. A gravura ${ }^{27}$ elaborada por Vico e desenhada por Domenico Antonio Vaccaro é rica nessa representação.

Entretanto, qual o percurso possível que Vico desenvolve acerca dos caracteres poéticos articulando-os segundo a estrutura de sua scienza?

Sendo exímio mestre em retórica, Vico parte da tópica sensível que desencadeou o engenho e a fantasia do homem primigênio na formação de um senso comum, para satisfazer as suas necessidades.

\footnotetext{
${ }^{26}$ Ibidem, [Cf. cap. IV, Corolários acerca da origem das línguas e das letras; e, dentro disto, a origem dos hieróglifos, das leis, dos nomes, das insígnias nobres, das medalhas, das moedas; e, portanto, da primeira língua e literatura do direito natural dos gentios, § 445, p. 280; Ei, p. 315].

${ }^{27}$ A gravura denominada por Vico de Tábua das coisas civis, tem como função expressar a idéia da obra $(\mathrm{Sn} 44)$.
} 
"Que os primeiros autores da humanidade se ativeram a uma tópica sensível, com que uniam as propriedades, ou qualidades, ou relações, por assim dizer, concretas dos indivíduos ou das espécies, e com elas formavam os seus gêneros poéticos

Segundo Vico, o engenho ${ }^{29}$ permite estabelecer relações entre as necessidades humanas e o mundo natural circundante, a imaginação transpõe significados do conhecido ao desconhecido induzindo o homem até a ação apropriada. As relações estabelecidas pelo engenho e pela fantasia permitiram aos infantes transformarem a natureza mediante a atividade, pois o engenho é a capacidade de compor na unidade a coisa separada e diversa, já que estabelece a medida das coisas.

Podemos observar na Ética nicomaquéa (VI,5,1140 b2-5) que Aristóteles distingue a atividade prática (praxis) da atividade criativa (poiesis); a primeira tem seu fim em si mesma, a segunda busca realizar um produto distinto da própria atividade. Essa distinção proporciona a clarificação daquilo que o engenho e a fantasia desenvolvem mediante o fazer viquiano: a fantasia mito-poética criou um complexo de figuras chamadas de "universais fantásticos" que modelaram o saber poético. Tais figuras proporcionaram as condições para o estabelecimento "prático" das instituições que constituíram o mundo das nações e as imagens míticas, bem como as instituições propiciaram a produção dos artefatos para satisfazer as necessidades e utilidades humanas (armas, utensílios, abrigos, instrumentos...).

A sapienza poetica na metafísica viquiana não pretende desenvolver um sentido "descritivo" da realidade para a consciência mítica, mas projeta um complexo de normas, deveres, cerimônias, cultos, presságios, auspícios, sacrifícios, fábulas, fazendo surgir a autoridade que se projeta sobre o mundo natural e das nações, formando estruturas que vão constituindo as instituições engendradas pelos autores do mundo civil. Estes legitimaram e cumpriram tais papéis que as instituições

\footnotetext{
${ }^{28}$ Ibidem., [Cf., Cap. VII, Últimos corolários acerca da lógica dos instruídos, tp. II., § 495, p. 321; Ei, p. 346].

${ }^{29}$ Sobre o engenho trataremos no Segundo Capítulo.
} 
propiciaram, a fim de manter viva a própria condição de família, de grupo, de povo, de nação, estabelecendo preceitos e obrigações gerados pelo sentido mítico emanados de suas consciências.

"Pois são os três trabalhos que deve fazer a grande poesia, isto é, encontrar fábulas sublimes ao entendimento popular e que perturbem excessivamente, para conseguir o seu fim, a que ela se propôs, de ensinar o vulgo a agir virtuosamente, como eles a si mesmos o ensinaram „30

Toda essa sapienza poetica só fora possível, porque os primigênios

“...por sua robusta ignorância, faziam-no em virtude de uma corpulentíssima fantasia e, porque era muito corpulenta, faziam-no com uma espantosa sublimidade... „31

Ora, a linguagem do mito foi definida por Vico em quatro tropos: metáfora ${ }^{32}$, metonímia, sinédoque e ironia ${ }^{33}$. Com exceção da ironia, estes tropos são operações básicas do pensamento mítico, enquanto a última só seria possível na idade dos homens capazes de abstrair, refletir e entender, pois ela é formada a partir do falso mediante uma reflexão verdadeira.

Na lógica poética, dentre os tropos aqui elencados, a metáfora seria a mais luminosa, a mais freqüente e a mais necessária, pois fornece sentido e paixão às coisas inanimadas, no prazeroso dizer de Vico. A metonímia e a sinédoque também têm sua origem na estrutura limitada da mente primitiva e na pobreza de seus recursos linguísticos. A metonímia, entre os povos primigênios, teria a função de transpor as causas pelos efeitos, os agentes pelos atos, e o sujeito pelas propriedades. Assim poderia explicar-se que o caráter poético de um deus ou de um herói é vivenciado pela mente

\footnotetext{
${ }^{30}$ Ibidem, [Cf., Secção Primeira, Metafísica Poética, cap. I, Da metafísica poética, que nos dá a origem da poesia, da idolatria, da adivinhação e dos sacrifícios, § 376, p. 213; Ei, p. 263].

${ }^{31}$ Ibidem

${ }^{32}$ Quanto ao tropo metáfora será exaustivamente analisado no cap. II, top. 2.4. e 2.4.2, p. 66,72., desta tese.

${ }^{33}$ Destaque em negrito.
} 
primigênia como um agente que causa determinados atos, ou como um sujeito que possui certas propriedades. A sinédoque consistiria na transposição do significado que eleva o particular à potência do geral, ou que unifica o todo a partir de suas partes. Esses três primeiros tropos seriam as três primeiras operações possíveis da mente primigênia que permitiriam a criação das figuras míticas percebidas pelos autores do mundo das nações, induzindo-os a conceber, estabelecer, conservar e transformar as instituições econômicas, políticas e sociais. Por isso, a teoria retórica da linguagem figurativa conteria a "chave mestra", segundo Vico, que permitiria explicar cientificamente o mundo das nações como criação da mente humana.

Nos elementos provenientes da tradição retórica e no desenvolvimento da tese acerca da sapienza poetica dos povos gentílicos, a doutrina retórica dos tropos (elocutio) e a dos topos (inventio) fornecem índices de confirmação e explicam o modo de funcionamento da mente primigênia. A retórica é a estrutura correspondente às Idades históricas da scienza nuova, já que pressupõe uma dependência recíproca entre as transposições da linguagem figurativa de um lado, e as modificações das mentes e as idades do mundo das nações de outro ${ }^{34}$.

Da mesma forma que temos esta relação entre a origem da linguagem paralela à origem das idades, vamos encontrar as sucessões das formas de governo dentro do curso histórico, às quais recorreram as nações, como a passagem da transposição de uma linguagem a outra. Observamos que a transição do pater família na era dos deuses ao governo aristocrático na idade dos heróis seria análoga à transição da identificação metafórica à redução metonímica. Isto se dá porque na idade divina os homens projetaram nos deuses seus próprios atributos e temeram aqueles aspectos desconhecidos de sua própria natureza. Enquanto na era dos heróis, estes passaram a se considerar deuses ou filhos de deuses e disporiam de poderes sobrenaturais ao assumirem atributos divinos. Percebe-se a sequência que se desenvolve nesta passagem: na era divina havia a projeção dos

\footnotetext{
${ }^{34}$ Ibidem, [Cf. cap. IV, Corolários acerca das origens das línguas e das letras; § 432, p. 263; Ei, p. 301].
} 
atributos humanos aos deuses e na era heróica a retro-projeção dos atributos humanos divinizados em atributos divinos humanizados

Na era dos heróis, a percepção metonímica permitiu que o mero ato de domínio dos nobres sobre a plebe se tornasse um ato de governo numa transposição do agente pelos seus atos; a transição do governo aristocrático para o democrático seria análoga à que vai da redução metonímica à expansão da sinédoque, uma vez que os plebeus reclamavam para si os atributos originalmente adstritos aos deuses, e logo reclamados pelos nobres numa transposição da parte pelo todo. Por último, na transição para o governo democrático, da lei e da recaída na barbárie anárquica e individualista seria análoga à que vai da sinédoque à ironia, porque nela se percebe a dicotomia entre a lei como linguagem articulada que enuncia o universal, e a realidade social que pretende reger. Percebemos, aqui, a cisão existente entre o estado e a nação, entre a lei e o cidadão, entre discurso e prática.

Essas três transposições da linguagem figurativa nada mais são que o modo peculiar de projeção que Vico realiza da estrutura e estética retórica para o mundo das nações, pela qual é possível projetar o conhecido sobre o desconhecido, formando uma cadeia que se interliga, demonstrando as passagens entre as diversas idades que vão compor a história da humanidade que se inicia com os bestiones, passa pelos infantes e heróis e chega aos humanos. Cada uma se realiza em tempos distintos: a metáfora projeta um significado sobre algo semelhante, a metonímia uma causa sobre o efeito, a sinédoque a parte sobre o todo e/ou vice-versa e a ironia, o discurso dissimulado.

Nesse encadeamento sucessivo descortinam-se os elementos cognoscitivos dos fenômenos naturais e históricos que permitiram a apreensão dos mecanismos subjacentes a essa estrutura elíptica, uma vez que seu movimento se dá em um corsi e ricorsi, numa ida e vinda constante, diferenciados entre si, distante pelo tempo e próximo pelos fatos, que foi pouco a pouco sedimentando-se e consolidando-se no fazer o conhecimento e no conhecer fazendo, permitindo a 
inter-relação do desconhecido com o conhecido de forma tropológica. Nessa trajetória os povos primigênios perceberam que a eficácia das leis, das normas, dos deveres e dos direitos só era possível mediante o seu arbítrio.

A lógica poética pretende indubitavelmente demonstrar que o mundo imaginário da sabedoria poética foi resultado de três operações da mente primigênia: a metáfora, a metonímia e a sinédoque, cuja correlação caracteriza os distintos tempos da história. Embora não explícito, Vico com sua maestria retórica soube muito bem delinear esse percurso tão bem articulado entre os elementos tropológicos.

Recorrendo ao trabalho filológico mediante os universais fantásticos, verificamos os efeitos dessas três transposições: a) quando a mente percebe o céu como um grande corpo animado (Zeus/Júpiter) e identifica metaforicamente o fenômeno natural inanimado do trovão com uma voz; b) identifica metonimicamente como causa dessa voz um emissor animado; c) a sinédoque estende a totalidade desse emissor ao atributo de potência vivido na intensidade do estrondo do trovão.

Parece óbvio que os tropos poéticos não se esgotam nesses três. Vico apresenta como fruto da engenhosidade dos povos primigênios além desses: o pleonasmo, a antonomásia, a comparação, a perífrase, a onomatopéia ${ }^{35}$. Esta última, muito utilizada pelos infantes para imitar os sons dos animais e dos fenômenos naturais, foi sem dúvida a primeira articulação provinda da imitação do som que acompanha determinada experiência no ímpeto da potente emoção que brota da boca dos bestiones em forma de canto, e as outras se desenvolveram entre os heróis.

Vimos a extensão da teoria dos tropos na Scienza nuova44, mas precisamos observar outro elemento retórico decisivo para uma melhor compreensão do modus operandi traçado por Vico de forma singularíssima que é a Topica sensibile, cuja referência na Scienza nuova44 pouco tem a ver com a arte retórica da descoberta ou do raciocínio dialético, pois a tópica sensível partiu de emissões conaturais do senso comum. Tratar-se-ia propriamente dessa gênese mental comum que é

\footnotetext{
${ }^{35}$ Destaque em negrito.
} 
a condição de existência dos argumentos utilizados pela maioria. A tópica sensível viquiana consistiria na base fixa da linguagem humana, que transcendendo o plano temporal da sensibilidade, transformaria a natureza em cultura. Seria a imperiosa necessidade para deixar o estado ferino e ingressar no estado civil, deixar de ser bestione para humanizar-se. Desse modo, os universais fantásticos viquianos se tornariam a tópica sensível .

A função de cada universal fantástico seria a de permitir identificar unidades de sentido fixas que transcenderiam o fluxo natural das sensações, metamorfoseando-se mediante o uso de termos para referir-se a outros significados através da criação lingüística do sentido da experiência ou, de forma mais plena, das vivências viscerais numa transosmose entre o homem e a natureza.

Nas suas obras, Vico distingue, entre outras, quatro funções retóricas: a taxionômica, a hermenêutica, a gnosiológica e a expressiva ${ }^{36}$. A primeira teria a função de organizar qualquer discurso integrando e articulando as partes que o compõem, coligando-as à lógica e seguindo a ordem da verossimilhança, não a do valor de verdade. Essas funções da retórica viquiana encontram-se fundamentalmente nas Oraciones Inaugurales. A função gnosiológica encontra-se no livro da Sn44 acerca Dos Elementos, cujo mote de Tácito, Vico transcreve "Omne ignotum pro magnifico est" ${ }^{37}$. A função hermenêutica cumpre o método de interpretação mitológica da poesia primigênia, e, por último, a função expressiva reconhece a fantasia como uma faculdade autosuficiente, independente da razão, embora dela não subtraída, mas, peculiar à mente completamente descolada da racionalidade reflexiva. O caráter retórico desenvolvido por Vico difere essencialmente da retórica tradicional que busca sempre a relação entre orador e auditor. Na Scienza Nuova, o seu caráter é eminentemente cognoscente, visando prover essa scienza de um estatuto , cuja autenticidade lhe conferiria uma legitimidade.

\footnotetext{
${ }^{36}$ Destaque em negrito.

37 "Tudo que é ignorado é considerado magnífico"
} 


\subsubsection{A epistemologia da Scienza Nuova}

Há, no entanto, uma questão de cunho epistemológico que foi o fundamento necessário para dar credibilidade não apenas à obra, mas precisamente a Vico, já que sua tese contrariava a maioria dos doutos da época, em especial, os cartesianos.

Ora, que percurso Vico trilharia para promover a sua ciência? Que elementos ele utilizaria para dar cientificidade à sua obra e defini-la como a nova ciência?

Decerto tais respostas, já intentadas acima, requererão maior distensão.

Percebemos na Scienza Nuova, a constituição de uma episteme do processo histórico, cujo princípio norteador se baseia na máxima “ipsum verum factum convertuntur”, que designa o meio pelo qual é possível o conhecimento. Só podemos conhecer aquilo que fazemos, aquilo que somos capazes de criar, considerando que tudo o que é resultado dessa criação faria parte da ciência humana; por conseguinte, toda obra humana poderia ser entendida cientificamente.

Vico assim descreve a natureza da ciência humana:

“Assim, esta ciência procede precisamente como a geometria, que constitui o seu próprio mundo das grandezas, enquanto sobre os seus elementos os constrói ou os contempla, mas com tanta mais realidade quanto mais a tem as ordens referentes aos assuntos dos homens, que não possuem pontos, linhas, superficies e figuras ${ }^{\text {,38 }}$

\footnotetext{
${ }^{38}$ Ibidem, [Cf., Secção Quarta, Do Método, § 349, p. 187, Ei, p. 245 ].
} 
A ciência viquiana se organiza a partir de uma delimitação de um campo concreto de investigação. Assim temos os 'objetos' que se apresentam na sua novidade e processo de forma visível, daí a necessidade de dar relevância há uma ruptura epistêmica que se daria pelo 'mito do dilúvio universal', que seria a condição das gênesis e desenvolvimentos da humanidade gentilesca a partir do qual é possível isolar um objeto de investigação para seu estudo, 'o mundo dos infantes' ou da gentilidade, do mesmo modo, isola també, a história hebraica. Em segundo lugar, os conceitos fundamentais utilizados por Vico para interpretar a história da humanidade gentilesca são os mesmos que, sobre um plano diverso, isto é, de um diferente contexto de significados, são usados no De Antiquissima , como bem salienta Badaloni:

"Primeiramente, para exemplificar, vale, como explicação teórica, que a ruptura resguarda o mundo dos fatos, não aquele da mente, que Vico chama 'pura' ou 'ingênua' e que constitui o continuum transcendental, cosmológico ou teológico, no sentido no qual Galileu dispôs por Deus os mundos no lugar da sua harmônica circulação...A ruptura é ainda repetição aos novos níveis simbólicos e nas diversas formas de vida. A relevância da necessidade da ruptura epistêmica, permite a documentação da continuidade dos 'significantes', estruturáveis em diferentes níveis"39

A Scienza nuova mantém as teses referentes aos fundamentos epistemológicos das matemáticas formuladas nos primeiros escritos (Liber Metaphisicus). A firmeza das verdades matemáticas não procede da claridade e distinção dos seus conceitos, mas do objeto sobre o qual predica, que é uma ficção criada pelo homem, pois a mente humana possui as causas desse objeto, uma vez que "Saber significa compor os elementos da coisa", porque são utilizados e dados mediante informações certas que, em função da origem da coisa, combinam-se através de determinados elementos e não outros, de tal modo que não se possa dizer que é certum ou non

\footnotetext{
39 Badaloni, N., Introduzione a Vico, [Cf., II. Il sistema delle scienze, 1. La formazione degli oggetti. Rottura e continuitá, p.42-43, Editori Laterza, , Settima edizione, Roma-Bari, 2008].
} 
certum, mas é qualquer coisa da qual se pode dizer que é verum ou non verum. E o critério para esclarecer qual desses dois termos será aplicado consiste em verificar qual combinação foi efetuada, e se o efeito mencionado foi obtido ou não: "veri criterium ac regulam ipsum esse fecisse" ("o critério e a regra da verdade consistem no havê-lo feito" ${ }^{40}$. É bom sublinhar que, segundo Isaiah Berlin,

"Vico foi um inovador audacioso no campo da lei natural, da jurisprudência, da estética e da filosofia da matemática; seu conceito de raciocínio matemático era realmente tão revolucionário que pouca justiça lhe pode ser feita até a transformação efetuada pelos logicistas do séc. $X X^{\prime},{ }^{41}$

O reconhecimento da matemática enquanto ciência, presente no De ratione e no Liber metaphisicus ressalta a impotência do homem em contraste com a consciência divina: "Só Deus pode conhecer a estrutura interna do mundo material, porque Ele o criou”. No entanto, na Sn44, ele apresenta uma realidade distinta da natural que tem sido criada pelo homem. Para ele a metafísica estuda o ente; a aritmética, o uno e a sua multiplicidade; a geometria a figura e a sua mensurabilidade; a mecânica o movimento da área e, a física o movimento do centro. No entanto, como o homem tem a mente limitada, não consegue perceber a natureza das coisas, pois diferentemente de Deus, ele não as possui e por isso utiliza-se de um artifício que é ficção ao compor um mundo de formas por meio da abstração.

Assim,

“...imagina dois elementos: o ponto que pode ser desenhado e o uno que pode ser multiplicado, sendo duas entidades fictícias, pois o ponto quando desenhado não é mais ponto e o

${ }^{40}$ Essa tese matemática de Vico contém o mesmo princípio da matemática ou físicalismo lógico, ou ainda positivismo lógico de Russel e Wittgenstein, na cognominada multiplicidade combinatória.

${ }^{41}$ I, Berlin [Cf. Teoria Geral/Primeira Parte, "Vico e Herder", ed. Universidade de Brasília, 1976, p.21]. 
uno multiplicado não é mais uno. Cria-se, assim, um mundo de formas e de números que abrangeria dentro de si todo o universo: alongando, diminuindo, compondo linhas, somando, diminuindo ou calculando os números, compondo infinitas operações, como se contivesse dentro de si verdades infinitas" ${ }^{\prime 2}$.

Dado o caráter arbitrário da matemática, Vico diferencia-se não só dos filósofos do Renascimento como também de Galileu, pois a matemática não é vista como a verdade que tem a capacidade de filtrar a natureza e reduzi-la aos números, porque estes são ficções criadas pelos homens, enquanto a natureza é criação de Deus.

Em seus primeiros escritos Vico enfatizou a falta de correspondência entre o caráter flutuante e contingente da vida civil e a regularidade que deve apresentar o objeto científico. $\mathrm{Na}$ $\mathrm{Sn} 44$, entretanto, formulam-se as ordens que regem as ações humanas, ordens essencialmente diferentes do more geométrico. O objeto que rege a sociedade civil não é uma ficção nem norma definida mediante convenção, mas tão somente um produto humano real.

No Lm, Vico faz valer seu princípio gnosiológico tanto para a Scientia Dei, quanto para a matemática que está intimamente vinculada ao ato criador. Daí a linguagem enquanto criação do homem, na qual estão imprescindivelmente unidos razão e ação, mente e vontade, que emergem de forma confusa e embrionária, cuja existência provém da criação divina manifestando o vínculo entre o homem e Deus, evidenciando a presença do divino no humano. Tanto o saber de Deus sobre o mundo natural quanto o saber do geômetra sobre as suas figuras fundamentam-se a partir do princípio de que só é possível conhecer aquilo que tem sido feito por quem o conhece. No entanto, essa identidade de princípio não se dá no conteúdo do saber, posto que o saber (scire) é estritamente humano, pois cada um conhece o que cria,: o homem a ficção, e Deus, toda a realidade natural.

\footnotetext{
${ }^{42}$ Vico, De ant. [Cf., Lm, Origine e verità delle scienze, cap. II, p. 66].
} 
Essa relação entre o saber divino e o humano encontra-se na Scienza nuova44 entre geometria e história, aquela estuda o objeto fictício, e esta o objeto real: o mundo das nações. O verdadeiro identifica-se com o fato, por conseqüência Deus é a primeira verdade, pois é o primeiro fazedor. Essa primeira verdade é infinita, é completíssima, pois Deus enquanto arquiteto de todas as coisas contém todos os elementos intrínsecos e extrínsecos das coisas, já que intelligere é ler perfeitamente, isto é, recolher todos os elementos das coisas e exprimir com perfeição. O pensamento (cogitatio) é próprio da mente humana, pois a faculdade de pensar é uma atividade psíquica pela qual o homem adquire conhecimento de si e do mundo no qual vive e, do mesmo modo, elabora conceitos, teorias e juízos, enquanto a inteligência (intelligentia) é própria da divindade, porque é a faculdade de todo o conhecimento universal. Deus de fato contém todos os elementos das coisas extrínsecas e intrínsecas, pois os contém e por isso os dispõem. No entanto, a mente humana sendo limitada pode somente reunir os elementos externos das coisas (as partes), sem, no entanto, reunir tudo, por isso é partícipe da razão, não sendo seu autor.

"Portanto, a verdade divina é aquela que Deus dispõe e gera no mesmo momento em que conhece, enquanto a verdade humana é aquela que o homem compõe e faz no momento em que aprende. Sendo assim, a ciência é o conhecimento do gênero ou modo no qual a coisa se faz" "43

Essa doutrina não é uma novidade para Vico, pois já havia sido comentada por scotistas e ockamistas, bem como no Renascimento. Marsilio Ficino na sua Theologia platonica já havia discorrido sobre ela. Obviamente, Vico a reveste de originalidade para refutar as teses cartesianas.

O princípio verum ipsum factum vale tanto para a mente divina quanto para a humana, e mediante essa equivalência Vico pretende mostrar o caráter divino da alma humana. No entanto,

\footnotetext{
${ }^{43}$ Ibidem, De ant., [Lm, Il vero e il fatto, cap. I, p. 62].
} 
esse princípio pode conduzir ao seguinte dilema, segundo Damiani ${ }^{44}$ : “ou bem a Sn44 não é o conhecimento verdadeiro do mundo civil, ou bem Deus ignora toda obra humana". Ora, se a alma é divina, então o homem conteria em si uma natureza divina, portanto poderia criar de forma onisciente. No entanto, no De ratione e no Liber metaphysicus e nas Orazioni inauguralis tal problema não poderia apresentar-se porque a ciência humana (a matemática) resulta da finitude do homem, da sua incapacidade para conhecer a realidade (natureza). E na Sn44 o homem conhece a realidade e não apenas ficções, pois a condição de possibilidade desta ciência, ou seja, do fato de que o homem tenha criado o objeto, isto é, o mundo civil, resultaria em que este seria incognoscível para Deus, posto que o homem seria o autor da história ou o princípio viquiano não valeria para o homem. Sendo assim, a Scienza Nuova não poderia conhecer o mundo civil.

Podemos considerar, segundo Damiani, uma nova condição epistemológica para interpretar as relações que a providência exerce na filosofia viquiana:

"Se há uma dimensão transcendente da Providência, ela não pode ser objeto da ciência verdadeira, senão só da consciência certa". ${ }^{45}$

Na Scienza nuova, Vico pretende demonstrar a regularidade ideal e eterna que rege o mundo civil (real e temporal) criado pelos homens, enquanto único conhecimento verdadeiro de Deus que pode ser atribuído ao homem.

"Portanto, uma tal Ciência deve ser uma demonstração, por assim dizer, de um fato histórico da providência, porque deve ser uma história das ordens que aquela, sem nenhuma

\footnotetext{
${ }^{44}$ A.M.Damiani, [Cf. 4.3. "A possibilidade da Scienza Nuova”, Domesticar a los gigantes/sentido y praxis en Vico, p.290], Damiani levanta essa questão da relação entre Deus e o homem, enquanto autor e criador das coisas, mediante o princípio ipsum verum factum convertuntur, posto que Deus enquanto autor tem conhecimento da sua ação criadora, enquanto o homem não se reconhece inicialmente como autor de sua criação.

45 Damiani, Domesticar a los gigantes [Cf. Posibilidad de la Ciencia Nueva, § 434, p. 292]. Esta di mensão transcendente da providência divina é reconhecido por alguns intérpretes católicos como Giuseppe Flores D’Arcais, Latinità dello storicismo vichiano, Padova, Cedam, 1940, pp.,xi-xii, xv-xvi.
} 
advertência ou conselhos humanos e, freqüentemente, contra esses propósitos dos homens, deu a esta grande cidade do gênero humano, pois, se bem que este mundo tenha sido criado particular e no tempo, porém, as ordens que ela nele pôs são universais e eternas ",46

No entanto qualquer outro conteúdo de consciência que tenha a Deus por objeto deve ser considerado como uma certeza e não como uma verdade. ${ }^{47}$

A aplicação do princípio verum ipsum factum ao mundo civil pode evitar o aparente dilema apresentado por Damiani, já que Deus é cognoscível pelas obras humanas, uma vez que a Providência age através das ações dos indivíduos.

“O mundo das nações é feito efetivamente pelos homens, porém isto não significa que a história permaneça inescrutável para Deus, como permanece a natureza para o homem. A estrutura da história não é mais que o plano que a Providência tem para o mundo humano e que seria para ela totalmente transparente ${ }^{48,}$

No De Uno ${ }^{49}$, Vico concluiu que o certum provém da autoridade, assim como o verum da razão. Embora o certum e o verum tenham proveniências diferentes, a autoridade não se opõe totalmente à razão, isso quer dizer que no certum há sempre um elemento de verdade (vis veri) introduzido pela razão. Por isso, a ordem do certum é a ordem da verossimilhança, daquilo que não

\footnotetext{
${ }^{46}$ Ibidem, [Cf. Secção Quarta, Do Método, § 342, p. 183; Ei, p. 241-242].

${ }^{47}$ Damiani adverte "que a diferença entre verum e certum é chave dos argumentos que aparecem no Liber metaphysicus contra o critério de verdade cartesiano. Somente diferenciando a certeza da verdade, é possível admitir que uma proposição evidente ou indubitável pode ser falsa. Vico sustenta no Lm que a filosofia crítica deve ser criticada fundamentalmente porque não cumpre com o seu objetivo explícito de refutar o ceticismo. A suposta verdade primeira (cogito ergo sum) que proporciona a filosofia crítica, não só não é primeira, diz Vico, como nem sequer é uma verdade. O cogito não é um limite que separa o cético do cartesiano, porque o cético não duvida de seu pensamento. Ambos admitem que estão pensando, ambos admitem o cogito: porém, embora o cético considere este fato uma certeza (certum), o cartesiano o considera uma verdade (verum)", [Cf. Domesticar a los gigantes, 4.2. La doctrina civil em las primeras obras, 4.3.6., p. 299].

${ }^{48}$ Ibidem, Domesticar a los gigantes, [Cf. § 4.3. Possibilidad de La ciência nueva, § 4.3.4., p. 293].

${ }^{49}$ Vico, Opere Giuridiche [Cf. De Uno, cap. 82-83, p. 100]
} 
é a verdade, mas dela se aproxima. Concluímos, então, que o certum em parte é verdadeiro. Mas, como a autoridade é uma concessão divina, ela procederia também da razão ${ }^{50}$.

Aparentemente, há na concepção viquiana uma contradição. No entanto, Vico considera do ponto de vista histórico, o certum provindo da autoridade, do livre arbítrio, posto que tal condição não garante uma simetria, isto é, não há na autoridade humana uma verdade absoluta. As ações humanas são incertas. Contudo, essa autoridade é concessão de Deus em sua infinita intelligentia, pois tudo se encontra nele e sua omnisciência é a razão puríssima. Há, aqui, uma dimensão transcendente da providência divina, que não pode ser objeto de uma consciência verdadeira no dizer de Vico, mas tão somente de uma consciência certa. Portanto, enquanto criaturas de Deus, a autoridade por Ele concedida provém da razão divina. Provavelmente, seja este o ponto crucial, que levou Croce a afirmar que Vico confundiu filologia e filosofia, o que mais adiante refutaremos.

\subsubsection{Filosofia e Filologia na trama da obscuridade}

Vico estende ao âmbito da história mediante a filologia, as teses que formulou para relacionar direito natural e direito positivo, levando em consideração o dito de Ulpiano: "a lei é dura, mas ela está escrita”, que, segundo Vico, quer dizer:

“...a lei é certa (tem autoridade legal), mas não é totalmente verdadeira, pois pode servir a qualquer razão que não queira que a lei seja totalmente conforme a verdade ${ }^{51 "}$.

\footnotetext{
${ }^{50}$ Ibidem [Cf., De Uno, cap. 93-94, p. 109]

${ }^{51}$ Ibidem [Cf. De Uno, cap. 82-83, p. 100]
} 
Na passagem observamos os primeiros sinais acerca de seu programa filosófico - que se ocupa do universal, racional e verdadeiro -, bem como do programa filológico - que se ocupa do particular, histórico e certo.

"Os dois vocábulos: "verdade” e "certeza” apresentam diferentes significações, tal como a distinção entre a verdade e a dúvida, assim também há uma diferença entre a verdade e a certeza, uma vez que, caso não houvesse tal diferença e diversidade, resultaria que muitas coisas verdadeiras, mostrando-se às vezes duvidosas, resultariam simultaneamente duvidosas e certas, e ao contrário, muitas coisas falsas que são consideradas certas, seriam falsas e verdadeiras simultaneamente. O verdadeiro nasce da conformidade da mente com a ordem da coisa, e o certo é produto da consciência assegurada pela dúvida, ${ }^{, 52}$

Como procederia a Scienza Nuova cientificamente, se também é considerada como uma "ciência da fantasia"?. Segundo Verene:

"A nova arte crítica ou crítica metafísica é uma ciência da fantasia na qual as coisas são compreendidas mediante os seus opostos. Como se observa no capítulo precedente, o desenho providencial da história é realizado por um gênero de movimento inverso àquele do processo histórico aparente ${ }^{53 "}$.

Vico classifica a fantasia em duas classes: a mítica ou poética e a reminiscente ou filosófica. A primeira constitui a mente poética que se manifesta mediante universais fantásticos, enquanto a

\footnotetext{
${ }^{52}$ Ibidem[Cf.,De Uno proloquium 27, p.34

${ }^{53}$ Verene, Vico, La scienza della fantasia, [Cf. La Scienza, cap. 5, p.157].
} 
segunda torna possível à Scienza Nuova ter acesso ao seu objeto para operar mediante universais da recordação.

A memória apreende as percepções adquiridas por meio dos sentidos através da reminiscência ou recordação quando exprime aquilo já adquirido pelas percepções, sendo por isso uma faculdade que representa as atividades produzidas pelas imagens, isto é, a faculdade que os gregos chamavam de fantasia e os latinos imaginativa. Este imaginar era dito pelos latinos memorare, certamente por terem observado que não podemos imaginar o que recordar e recordamos somente o que percebemos. Assim como nasce a mente humana do primeiro universal fantástico que possibilita perceber o raio como Júpiter, a Scienza nuova se dirige ao primeiro universal da recordação, que permitiria a apreensão da sucessão temporal como uma história ideal eterna.

Não podemos decerto com singular simplismo considerar que Vico não distinguiu filosofia e filologia. No De uno, acima citado, ele faz a distinção entre os dois vocábulos: certum e verum, bem como na Scienza Nuova $§ 7$ define as formas de ambas e considera o papel da filosofia enquanto condição teórica e conceitual para fundamentar a filologia enquanto ciência, imprimindo-lhe bases epistêmicas.

Croce fez uma leitura idealista ${ }^{54}$ da teoria viquiana ao considerar a distinção dialética entre o particular e o universal, pois o seu conceito de história se põe sobre um plano absoluto que pretende resolver em si o concreto, excluindo o empírico e a generalidade, as quais se reduzem às

\footnotetext{
${ }^{54}$ Croce é considerado um neo-hegeliano e um neo-idealista italiano, embora discordasse de um espírito especulativo que partia de uma filosofia a priori da Natureza e de uma construção puramente especulativa da história [Cf., Mora, F., Dicionário de Filosofia, ED. Loyola, tomo I, p. 121, SP, 2000] . Partindo daqui, ele confunde a crítica filológica viquiana enquanto elemento negativo aprioristicamente considerada, mas concordava com a dialética, enquanto primazia do pensamento na compreensão da realidade e da descoberta do Espírito, que mais parece viquiano, embora ele não o considere, pois que esta dialética é uma absorção dos diferentes graus por uma síntese que não é uma supressão, mas a afirmação do diferente, que corresponderia ao verossímil viquiano, aquilo que comporta o diverso unitariamente ou, o múltiplo na diferença, quando discorremos acerca do certum nesta tese. A historiografia teórica e prática de Croce resulta na universalidade concreta do espiritual, como a História Ideal Eterna de Vico resulta na história dos homens. Por isso, Vico, Hegel e Croce se opõem à pura racionalidade cartesiana porque conhecem o valor e a função da evolução espiritual, em particular, da história, que só pode ser entendida de acordo com Croce do ponto de vista do Espírito concreto e absoluto. Em Badaloni, Croce, em vez de separar os fatos empíricos, como fez Vico, invocava uma eterna filosofia do espírito e escreve: "Se pode, embora nem tanto, se definir paradoxalmente, a filosofia de Vico, como uma filosofia do espírito com particular precaução à filosofia da fantasia". [Cf. Introduzione a Vico, L'interpretazione idealística e La discussione contemporânea su Vico, p. 164].
} 
manifestações políticas, econômicas, jurídicas e sociais, que para Vico constituíram um momento imprescindível da história. Segundo Isoldi ,

“A síntese entre o particular e o universal, da sensação e idéia, que caracteriza a poesis fantástica viquiana, e a síntese de auctoritas e racionalidade que é para Vico o fundamento do mundo civil, comparado ao sistema dos distintos deuses crociano, foi de um equívoco insustentável, o qual tende a considerar como motivo marginal, que é necessário omitir essa parte se se quer verdadeiramente entender o pensamento viquiano" ${ }^{, 55}$.

Sem perceber a arquitetura que Vico imprimiu dando-lhe coerência e funcionalidade, influenciando decisivamente vários campos do saber: a educação, a antropologia, a estética, a literatura, a história e a sociologia, entre outros. Croce ao afirmar que a obscuridade de Vico

“...consiste verdadeiramente em uma obscuridade de idéias, na deficiente inteligência de certos nexos e na substituição com certos nexos falazes, no elemento arbitrário que por isto se introduz no pensamento, ou para dizer de um modo mais simples, na verdade são os próprios erros, 56

É de causar perplexidade a incoerência de Croce ao dizer que

“...embora Vico não fosse muito perspicaz, era sempre muito profundo ${ }^{57}$.

\footnotetext{
${ }^{55}$ Isoldi, A., G.B.Vico, La vita e Le opere [Cf., La fortuna di G.B.Vico, cap. VIII, Le interpretazioone idealistiche, , Cappelli, 1986, p. 445].

56 B.Croce [Cf. "Structtura Interna della Scienza Nuova”, Bari, quarta edizione riveduta, p. 39, Filosofia del Vico]. Croce apresenta certas contradições ao longo desse parágrafo. Embora realce a obscuridade das idéias de Vico, "agita o espírito do leitor e propaga a onda do pensamento quase por vibração simpatética". "Simpatético" quer dizer "que concorda perfeitamente com o pensamento ou o caráter, a característica, a qualidade de uma pessoa ou de uma coisa". Parece-nos que o leitor, segundo Croce, é completamente desavisado.

${ }^{57}$ Em negrito para destacar a incoerência de Croce sobre Vico.
} 
Que profundidade é essa se suas idéias são obscuras, se há deficiência de certos nexos e, deveras, comete erros? Croce ao interpretar a Scienza Nuova não leva em consideração a ordem do certum que a compõe, nem o procedimento segundo a ordem geométrica, pois assim como o geômetra constrói as suas formas, o homem faz a história, tratando-se nos dois casos de objetos construídos pelo homem ao estabelecer os nexos funcionais e ao remetê-los com perspicaz engenhosidade para a linguagem e a história, como podemos observar na feitura da obra, tanto do ponto de vista formal, ao estabelecer as conexões entre os princípios e as doutrinas em vista de uma demonstração, quanto na sutil originalidade da correlação entre filosofia e filologia inovando um modo de pensar.

\section{Amério considera}

“...que Croce teve a pretensão de descobrir o verdadeiro Vico, o grande Vico, o filósofo Vico! Quando o reduz a tal grau de incipiência de não saber aquilo que escreve, de não entender aquilo que diz, de acreditar em suma de raciocinar por Deus, embora raciocine pelo homem, e de ser católico embora fosse crociano", 58

Ora, a filosofia que Vico professa é aquela da ordem do verum que se converte em fato por sua conformidade entre a mente e a coisa, não se tratando, portanto, de uma contradição, mas sim do princípio sem o qual ele não poderia pensar coerentemente a história das nações, bem como não poderia traçar uma gênese da história que, conjugada à filologia da ordem do certum, permitiu desenvolver e desvendar determinadas hipóteses acerca da linguagem, da história e da ciência. ${ }^{59}$

${ }_{58}^{58}$ F.Amerio, [Cf. Introduzione allo studio di G.B.Vico, S.E.I. Torino, 1947, p. 274]

${ }^{59}$ A filosofia contemporânea, por exemplo, que versa sobre a linguagem como podemos observar em Russell e Witgenstein (cuja obra Tractatus Logicus Philosophicus foi considerada enigmática por muitos comentadores), classifica a concepção destes de empirismo lógico e/ou positivismo lógico, ou ainda 
Percebe-se que Croce não conseguiu interpretar o pensamento viquiano com fidelidade, considerando-o, por esse motivo, obscuro. No entanto, do ponto de vista estético-literário, exalta a genialidade viquiana. Assim, outros autores, como Berlin, consideraram seu estilo barroco, indisciplinado e confuso, mesmo assim

"suas idéias são de uma novidade impressionante... um pensador fecundo"

No entanto, num ensaio posterior reconsidera sua posição, enaltecendo o pensamento viquiano pela sua originalidade e ousadia ${ }^{60}$. Na sua época, Vico também foi considerado obscuro, não por conta da confusão alegada por Croce, nem pelo barroquismo alegado por Berlin, mas porque se deteve na Imaginação como eixo do conhecimento, faculdade que fora desprezada pelos cartesianos como fonte de erros e falácias.

Vico ao tratar da origem da linguagem nos tempos bárbaros, na idade dos deuses, sem dúvida por sua vasta cultura latina, foi um estudioso do pensamento medieval. Parece-nos, pelo procedimento utilizado para reportar-se ao passado longínquo dos povos primigênios, que ele combinou, a indução baconiana, a retórica e a filologia, que comporta um mecanismo retroprojetor na investigação arqueológica da linguagem, por conter em sua metodologia investigativa a diacronia $^{61}$, a hermenêutica, a exegese e a etimologia, a condição histórica, a interpretativa, a

\footnotetext{
atomismo lógico, em que a proposição definida como empírica diz o fato, ou o nega, porque parte do princípio de que a estrutura da linguagem é similar à estrutura do mundo. Nem por isso podemos afirmar que há uma confusão entre filosofia e experiência, pois aquela fornece as propriedades constitutivas do objeto a ser investigado e esta, os fatos que a compõem, ou seja, a história enquanto ação na concepção viquiana

${ }^{60} \mathrm{I}$. Berlin, [Cf. "O divórcio entre as ciências e as humanidades", Estudos sobre a humanidade, Editora Schwarcz, São Paulo, 2002, p.362/III]. Publicado pela Universidade de Illinois em 1974. Nesse ensaio IB discute a possibilidade que Vico apresenta mediante a imaginação de um retorno ao passado remoto/mítico.

${ }^{61}$ Quanto ao caráter diacrônico da Sn44, Francesco Botturi nos dá uma indicação interessante: “A nova ciência interpretativa é tal, porque se refere a um saber que já aconteceu e que sempre acontece, isto é, pela espontânea criação hermenêutica da mente, que não está à disposição do sujeito, mas da qual sobretudo o sujeito está disposto; antes é providencialmente disposto, no momento em que aquela disposição constitui-se e salva a sua experiência da catástrofe histórica da ausência de sentido.

Poder-se-á ler esta concepção antropológica viquiana em termos de Geworfenheit, se a entendermos em sentido transcendental, isto é, não só como empírico alcance na condição histórica, mas antes, e mais
} 
origem semântica e a origem formativa dos vocábulos. Isso lhe permitiu conceber as épocas, os costumes, a linguagem, o conhecimento e a história como processos dinâmicos, em que cada povo, cada civilização tem seus modos peculiares de desenvolvimento numa escala diferenciada, e que, por isso, não podem ser vistas entre si como as superiores ou inferiores. Cada uma tem o seu modo de ser e só pode ser analisada a partir de suas peculiaridades, costumes, leis e instituições, não cabendo formas de comparação com outros povos ou civilizações, pois cada uma é o que é pela ação implementada por seus agentes, daí a essência mesma do homem não ser algo imutável, inalterável, mas passível de transformações.

O caráter combinatório peculiar ao seu engenhoso trabalho, a Scienza Nuova, fruto do manejo percuciente da retórica, permitiu-lhe estabelecer as interconexões entre esses elementos (conatus, senso-comum, imaginação, intuição, engenho, livre-arbítrio, filosofia e filologia), tal qual se apresenta no estilo redacional e argumentativo da sua obra, compondo um arcabouço fecundo para a interpretação do mito, arrojado na constituição de um saber poético, inovador na temporalidade histórica e esteticamente bem elaborado. Esse arranjo estruturante da Scienza Nuova procede precisamente como a geometria (\$ 349), posto que é uma Ciência demonstrativa de um fato histórico da providência, pois é uma história de ordens universais eternas que nos propicia provas teológicas naturais, segundo Vico. Seu cálculo geométrico difere do cartesiano, já que não segue a mensuração matemática, segue, sim, a probabilidade espiralar ${ }^{62}$., recurso este de natureza metafórica.

Percebemos duas tendências que se confrontam com o cartesianismo: aquela acerca do critério de verdade que se opõe a ele e, por Vico é entendido como capaz de fornecer uma justificação da preeminência da matemática sobre as outras ciências, que seja melhor que a fornecida por Descartes; tal preeminência não era posta em dúvida por Vico. Esse novo critério de

\footnotetext{
profundamente, como o ser dado a si mesmo na mente (e do seu operar hermenêutico), que diacronicamente chama-se também "história ideal eterna" [Cf. Ermeneutica dell'evento, La filosofia pratica tra metafisica e antropologia nell'età di Wolff e Vico, p. 456].

${ }^{62}$ Quero dizer que, sendo a concepção viquiana da ordem do certum, não se trata de linhas herméticas, fechadas entre si, mas do seu movimento que dinamiza-se mediante um contínuo entorno e retorno.
} 
verdade foi usado na sua teoria dos pontos metafísicos ${ }^{63}$ (como havemos de ver no segundo capítulo desta tese), para sustentar e servir a uma física mais indutiva e experimental que a de Descartes. A segunda tendência é a que lhe permitiu criar uma nova ciência da história que substitua a matemática como ciência exemplar daquilo que é considerado como verdadeiro ou inteligível; a criação de tal ciência utilizava a pesquisa histórica e filológica desprezada pelos cartesianos, pois utilizava critérios verossimilhantes da ordem do certum.

\subsubsection{O estilo viquiano}

Quanto ao estilo de Vico, o texto exaustivo de Mario Fubini ${ }^{64}$ o considera:

“...livre da estrutura de um esquema que parece tolher a sua vitalidade e por isto a eficácia sobre o ânimo dos leitores. E se nesta, como em todo o discurso que se faz da Sn44, - agora composta na forma definitiva quando ele pronunciava aquela palavra, - a obra é, se entende, subentendida tacitamente, o que nos permite colher o significado preciso do ideal oratório do qual Vico se faz defensor: a Sn44 não poderia adaptar-se aos procedimentos da escolástica, da qual, também, o seu gosto de humanista o tornava desconfiado, e nem menos ao novo método geométrico dos cartesianos, ao qual, todavia, ao menos exteriormente poderia conformar-se”.

Vico, por sua formação e profissão, possuía uma grande e refinada perícia lingüística; a sua prosa constituía-se sempre numa contínua conquista que se renovava a todo momento, diversificando o vocabulário empregado, numa demonstração árdua do trabalho redacional que ele

\footnotetext{
${ }^{63}$ Vico, De ant. [Cf. I punti metafisici e i conati, II, cap. III, p. 84-94].

${ }^{64}$ M.Fubini, [Cf. "La lingua del Vico", Stile e umanità di G.B.Vico, Riccardo Ricciardi Editore, Milano, 1965, p.84]
} 
se impôs; uma composição riquíssima em latinismos por ele cultivados, robustíssima em vivas imagens e lingüisticamente sugestiva.

Temos, portanto, exemplos históricos que marcam os veios que as concepções filosóficas podem tomar na diversidade das direções conceituais, não cabendo, portanto, críticas que não sejam fiéis ao pensamento de um determinado autor. É preciso ver com os olhos do autor a sua obra ou cometeremos injustiças na tentativa de uma desqualificação ingênua.

Desenvolvemos as refutações aos cartesianos ao longo do texto seguindo fidedignamente a concepção, os argumentos, o modo de condução que Vico constrói ao combinar filosofia e filologia, retórica e história, verum e certum.

A busca de uma base que fundamente a Scienza Nuova observa-se em dois tipos de argumentos, isto é, dois modos de argumentação de juízos: aquele que se refere às propriedades essenciais da natureza humana e parecem independentes dos demais, e justificam-se de acordo com as "modificações da mente humana", isto é, dos bestiones para os heróis e para os humanos. E a reminiscente que apresenta um caráter de tentativa, e sua confirmação vai depender de suas consequiências filológicas pela indução.

O recurso à indução foi herança baconiana, cuja pretensão não é proporcionar provas convincentes de sua verdade conclusiva por meio de premissas estabelecidas, mas tão somente fornecer algumas provas daquilo que se investiga e podem, sim, ser avaliadas como melhores ou piores segundo o grau de verossimilhança ou probabilidade que as premissas conferem às respectivas conclusões, cuja comprovação das premissas se realiza segundo o modelo de Francis Bacon para as coisas naturais desenvolvido no seu livro Cogitata et visa (1609), que Vico transpôs para as coisas humanas.

"Provas filológicas essas que servem para nos fazer ver, de fato, as coisas meditadas em idéia acerca deste mundo de nações, segundo o método de filosofar do senhor de Verulam, que é 
“cogitare videre”; pelo que, através das provas filosóficas anteriormente feitas, as filológicas, que se sucedem em seguida, chegam ao mesmo tempo e vêm a ter confirmada a sua autoridade com a razão e a confirmar a razão com a sua autoridade

Gadamer $^{66}$ tece considerações acerca da concepção spinozana que estendemos à concepção viquiana por sua pertinência:

“...se retrocedermos à pré-história da hermenêutica histórica, teremos de destacar, em primeiro lugar, que entre a filologia e a ciência da natureza em sua primeira auto-reflexão se estabelece uma correlação muito estreita que se reveste de um duplo sentido. Primeiramente, a "naturalidade" do procedimento científico-natural deve valer também para o posicionamento frente à tradição bíblica, e para isso serve o método histórico. Mas, ao inverso, também a naturalidade da arte filológica exercida na exegese bíblica, a arte de compreender pelo texto, coloca ao conhecimento da natureza a tarefa de decifrar o 'livro da natureza',"

Nessa medida o modelo da filologia pode orientar a investigação acerca da hgistória do mito. Decerto nos parece que Vico segue a tradição baconiana da indução, aquilo que não é evidente torna-se compreensível através de um rastreamento histórico. Há, portanto, em Vico, a necessidade de se pensar o passado remoto mediante um princípio interpretativo que a filologia é capaz de fornecer sem a necessidade de comprovações experimentais. Desse modo, as colocações de Gadamer vem ao encontro da metodologia viquiana presente na sua arte filológica, dando, assim, um caráter verossímil a sua scienza.

\footnotetext{
${ }^{65}$ Ibidem, [Cf. Secção Quarta, Do Método, § 359, p. 190; Ei, p. 248].

${ }^{66}$ H. G.Gadamer [Cf. Segunda parte "A extensão da questão da verdade à compreensão nas ciências do espírito", Verdade e Método, Editora Vozes, terceira edição, Petrópolis, 1999, p.284-285]. Gadamer tece considerações acerca da concepção spinoziana que estendemos à concepção viquiana por sua pertinência.
} 
Assim procedendo, a teoria dos caracteres poéticos permitiria ao historiador alcançar o entendimento das idéias dos primeiros autores do mundo das nações, daí o uso da retórica na Scienza Nuova enquanto teoria dos caracteres poéticos - como condição de universalidade e necessidade dos princípios da scienza. Para isso Vico transforma a retórica como ferramenta para interpretar as operações mentais (imaginação, senso comum, engenho etc...) dos autores do mundo das nações tornando-as objetos de sua Scienza Nuova.

A filologia, ao estudar a origem do mundo das nações deve descobrir os princípios universais e eternos que estão presentes nas instituições humanas criadas pelo homem em todas as nações antigas e modernas.

Os princípios universais e eternos apresentados na Scienza Nuova são os juízos sem reflexão, adquiridos por todo o gênero humano, denominados "senso comum do gênero humano", isto é, a capacidade que permite ao homem estabelecer determinadas relações entre as coisas, como a capacidade de formar grupos, pois o que proporciona a vontade ao homem não é a universalidade abstrata da razão, mas a universalidade concreta que representa a comunidade de um grupo, de um povo, de uma nação. O senso comum, portanto, é fundamental e decisivo para a vida e a formação do mundo das nações, pois contém em si um princípio regulador (intuitivo) que fornece o conhecimento direto e imediato, isto é, elementos puros e não adulterados de informação que apreendemos de forma elementar e certa, mas que vão além da pura recepção das coisas ou da realidade ao induzir à ação, a fim de que se estabeleçam formas de ligação daquilo apreendido com outras situações iminentes, através de associações que se fortalecem pela repetição, memorizandose e criando o hábito.

A este respeito lemos na Ciência Nova, o seguinte:

“Agora, uma vez que este mundo de nações foi feito pelos homens, vejamos em que coisas perpetuamente concordaram e ainda concordam todos os homens, porque tais coisas poderão 
fornecer-nos os princípios universais e eternos, tal como devem ser de toda a ciência, sobre os quais surgiram todas as nações e todas se conservam ",67

O saber prático (phronesis) é outra forma de saber que permite ao homem lidar com as situações concretas, abrangendo as circunstâncias em sua infinita variedade, direcionando-se por um motivo ético, positivo, mediante o conatus, que propiciou aos homens primigênios formar grupos e criar instituições. Vico pretende provar filologicamente que em toda nação, tanto antiga quanto moderna, surgem três instituições universais com ritos solenes: religião, matrimônio e sepultura, que compõem os três princípios da Scienza Nuova. Embora as nações tivessem sido fundadas em tempos e lugares diversos, todas conservaram esses três costumes humanos, pois “idéias uniformes, nascidas em povos desconhecidos entre si, devem ter um princípio comum de verdade, 68 .

Com a religião, temos a primeira manifestação mística do homem primigênio. Aterrorizado pelos trovões e tempestades, homiziava-se nas cavernas com temor de Ios. O matrimônio permitiu a formação da família, das linhagens e da civilização, a extinção do estado nefário, a sedentarização e a propriedade privada. O sepultamento propiciou a noção de imortalidade da alma e o ritual fúnebre, a passagem para a eternidade. Essas três certezas constituem o sentido comum do gênero humano, permitindo formular legitimamente juízos universais sobre o mundo das nações, que são princípios da ciência do mundo das nações. Assim, a sua ciência parte de princípios universais que se referem ao universal e eterno. Dessa forma, a Scienza Nuova cumpre com as exigências de universalidade e eternidade consignadas no preceito aristotélico "scientia debet esse de universalibus et aeternis" $"$. Portanto, o sentido comum a todas as nações e a versão objetiva da providência em transformar as paixões em virtude e imortalizar a alma constituem os dois pilares universais da Scienza Nuova.

\footnotetext{
${ }^{67}$ Ibidem, [Cf. Secção Terceira, Dos Princípios, § 332, p. 172; Ei, p. 232].

${ }^{68}$ Ibidem, [Cf. Secção Segunda, Dos Elementos, $\S 144$, p. 111].

69 "Os objetos das ciências deverão ser as coisas universais e eternas"
} 
Na idéia postulada por Vico de ciência, percebe-se uma contraposição à idéia moderna de mensurabilidade, porque era mais lata e absorvente, singularmente proveniente da história do homem que não reduz a ciência a um esquema matemático; pelo contrário, foi mais realista que seus contemporâneos dispondo de uma forma de fazer ciência, pela qual o homem é seu autor decisivo. A visão filológico-histórica de Vico alicerça-se no conceito de senso comum (sensus communis), proveniente da natureza incerta do arbítrio humano que produz juízos carentes de reflexão, e, por isso, o seu objeto, que é a existência moral e histórica do homem, ocorre de forma circunstancial, tal qual a natureza da filologia, que é incerta e indeterminada como a probabilidade dos fatos históricos.

Daí, a sua crítica ao cogito cartesiano a partir do princípio filológico - o certum - foi, além de coerente, fundamental, para desfazer as pretensões de Descartes acerca da verdade, pois considerou que Descartes não fez a distinção entre o que é verdadeiro, o verum, e o que é certo, o certum, e conseqüentemente entre consciência científica, a scientia, e a consciência, conscientia. Para Vico a scientia que postula o objeto verdadeiro exige uma consciência de causa, uma consciência que se refira a uma forma, a partir da qual pode criar-se a si mesma, uma vez que, no cogito, o sujeito pensante descobre a si mesmo como um certum, encontra-se a si mesmo como uma certeza, da qual é indubitavelmente conhecedora. No entanto, a consciência do indivíduo, do próprio ser não é uma scientia de sua verdade, pois o critério do verdadeiro não exige algum momento de produtividade. O cogito é simplesmente uma apresentação extraordinária de qualquer coisa que é certo ${ }^{\mathbf{7 0}}$, e deste extraordinário certum, este ato excepcionalmente potente da consciência não consegue gerar o verum, isto é, a consciência da causa, já que o certum implica sempre uma relação externa entre o conhecimento e o objeto, porque não é convertível como o factum, pois o cogito opera como aquele definitivo interno, como já mencionamos anteriormente em 1.2.1. desta tese.

\footnotetext{
${ }^{70} \mathrm{Em}$ negrito para realçar a condição viquiana do cogito.
} 
Ora, o caráter externo da prova certa de qualquer coisa que seja objeto de consciência, sem, no entanto, ser a sua causa, explica a áspera crítica que Vico fez em relação à prova cartesiana da existência de Deus, considerando uma blasfêmia extravagante, desqualificando-a de forma pungente, pois nem a prova da existência do eu, nem a da existência de Deus oferecem o critério da verdade.

O que Vico quis dizer foi o seguinte: a admissão da inteligibilidade da prova ontológica forneceria somente um sinal, caso também fosse certo, da existência de Deus. No entanto, não forneceria qualquer conhecimento acerca de Deus, algum conhecimento da sua causa, em suma, a causa sui de Deus; caso isso ocorresse, poderíamos criar deus.

Entretanto, a prova ontológica é considerada no sentido lato do pressuposto da racionalidade na experiência ${ }^{71}$, tal qual se encontra na interpretação idealista contemporânea de inspiração cartesiana, que consiste em fundamentar toda a evidência no Cogito, como afirma Descartes:

“E, assim, reconheço muito claramente que a certeza e a verdade de toda ciência dependem do tão-só conhecimento do verdadeiro Deus: de sorte que, antes que eu o conhecesse, não podia saber perfeitamente nenhuma outra coisa. E, agora que o conheço, tenho o meio de adquirir uma ciência perfeita ${ }^{72}$ no tocante a uma infinidade de coisas, não somente das que existem nele mas também das que pertencem à natureza corpórea, na medida em que ela pode servir de objeto às demonstrações dos geômetras..., ${ }^{, 73}$.

\footnotetext{
${ }^{71}$ A racionalidade na experiência implica a condição de que todas as coisas constitutivas do mundo encontram-se já dadas no cogito, enquanto objetos da consciência e que mediante a intencionalidade são objetivados através dos modos de consciência desenvolvidos por Hurssel na sua Fenomenologia Transcendental, [Cf. Coferências de Paris, Ed. 70].

${ }^{72}$ Em negrito para destacar a pretensão do conhecimento de uma ciência perfeita.

${ }^{73}$ Descartes, Meditações [Cf. Meditação Quinta, § 15, p. 128]
} 
A existência de Deus é demonstrada analiticamente da noção de Deus presente no cogito indubitável. Enquanto que, na prova ontológica como tradicionalmente se entende, Deus se manteria fora da nossa finitude, não conteria a forma mediante a qual poderíamos ser produtores do ser de Deus ou da verdade, como o certum do cogito na prova ontológica de Deus que resulta num objeto da consciência.

Ora, se não somos produtores do ser de Deus como se daria a participação e a covalidação do princípio verum factum?

No De ant., escrito num estilo de um sistema metafísico tradicional, composto de um apêndice da lógica, o Lm, em que ele discorre acerca do verum e do factum, e sobre a hermenêutica desses termos, Vico demonstrou a compreensibilidade conceitual desses princípios. ${ }^{74}$

Segundo Verene, a idéia do verum factum apresentada por Vico constituiria a plena justificação desse princípio. Porém, a sua origem derivada da língua latina seria duvidosa. Entretanto, Verene não apresenta outra possível justificação.

Vico, ao utilizar a filologia para descobrir e desvelar a natureza e a história do mito dandolhe um caráter metodológico herdado de Bacon como acima já comentamos, desenvolve suas investigações realizando descobertas inéditas acerca do mito, como verificamos na Ilíada e Odisséa, obras que foram matéria de análise filológica a qual resultou na descoberta de que Homero não foi um personagem histórico, mas uma tradição oral dos cantos épicos, poemas que os rapsodos conservavam na memória e anunciavam na Grécia, pelas feiras e festas:

“...de acordo com as origens das duas palavras, das quais esse nome de "rapsodo" é composto, eram “urdidores de cantos", que devem ter recolhido não certamente de outros, mas dos

\footnotetext{
${ }^{74}$ Fisch ao comentar sobre tais princípios, associa-os à tradicional noção metafísica da "transcendência", pois verum é um transcendes próprio da concepção metafísica medieval e é "convertível" com outros elementos da tradição, os quais - ens, unum, bonum (ser, uno e bom) - Fisch afirma serem superiores às categorias e se aplicam a todo ser, fazendo referência não às proposições, mas à verdade da coisa. Fisch sustenta que verum está para verdadeiro no sentido transcendente, e mais precisamente por inteligível. No entanto, se a tradição não compreende no seu elenco a identificação recíproca de verum e de factum, essa, no entanto, funda a sua raiz na doutrina medieval de Deus, o fazedor, como verificamos acima. Max H. Fisch [Cf. Vico tra Cartesio e Peirce, p.71-77], Leggere Vico, Giorgio Tagliacozzo e di altri, 1982.
} 


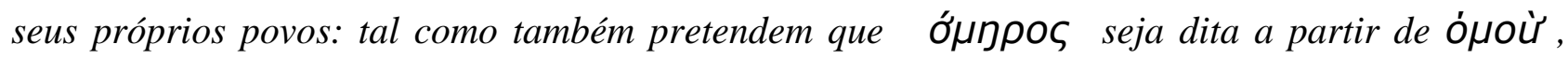
"simul", e elp o credor ao devedor. Origem essa que é tão longínqua e forçada quanto é plausível e apropriada para significar o nosso Homero, que foi o que ligou, ou seja, compôs as fábulas",75

Vico foi mais além, ao desenvolver análises comparativas em relação ao período histórico em que foram elaboradas. Observou discrepâncias entre elas, bem como entre costumes, entre povos, culinárias, produtos etc. No entanto, esse achado em nada diminuiu a decisiva importância que essas obras trouxeram para os estudos e investigações realizados.

“...que este Homero tenha sido uma idéia, ou seja, um caráter heróico de homens gregos, enquanto esses narravam $\mu$ ữựo, cantando as suas histórias" ${ }^{, 76}$

Ora, muito foi dito acerca da filologia de forma desdenhosa numa tentativa presunçosa para desqualificá-la enquanto método capaz de proporcionar ao pesquisador elementos úteis na investigação sobre a origem do homem. Entretanto, muitos também a utilizaram como instrumento de fundamentação, como observamos em vários filósofos como Platão, Nietzch e Heidegger entre outros.

A filologia, enquanto ordem do certum, propiciou a retomada da cultura mítica por Vico, a fim de extrair elementos lingüísticos que fornecessem respostas para as suas investigações.

\footnotetext{
${ }^{75}$ Ibidem, [Cf. cap. VI, Provas filológicas para a descoberta do verdadeiro Homero, tp. XIII, § 852, p. 634; Ei, p. 570]

${ }^{76}$ Ibidem, [Cf. Secção Segunda, Descoberta do verdadeiro Homero, Introdução, § 873, p. 644; Ei, p. 577].
} 


\subsection{A natureza da filologia}

Como poderia a linguagem fornecer elementos que corroborassem as hipóteses de Vico? Como a filologia, enquanto arte crítica, serviria de instrumento para a sua pesquisa? Que relação possível poderia Vico estabelecer entre o método filológico e a linguagem que assegurasse e justificasse suas proposições?

Observamos que a linguagem, na acepção platônica, é comparável ao movimento da lançadeira que, ao separar os fios da trama, compõe simultaneamente uma unidade entre a diferença e a identidade. Assim, os nomes, ao separar, distinguem porque nomeiam as coisas, e, ao dotarem tais coisas de identidade, permitem conhecê-las. Esse movimento do unir e do separar sublinha o caráter vago entre a palavra e a coisa e, provavelmente, é nessa ausência entre tais elementos que se forma a natureza incerta da ciência filológica. ${ }^{77}$

Do ponto de vista lingüístico-estrutural, a origem da linguagem é sempre obscura, construída na dispersão dos sons, no estranhamento da realidade e no temor dos fenômenos naturais. Essas situações vividas pelos primigênios, incidem sobre a emissão dos nomes às coisas enquanto referências, seja o estrondo de um trovão, seja o espanto de determinadas circunstâncias, sejam, enfim, os mais variados ruídos provindos da natureza e das paixões. E é nessa ausência irremediável e contingente que emerge a natureza mesma da Filologia numa busca constante da origem da linguagem através da verossimilhança, do provável, excluindo qualquer exatidão matemática de sua filogênese. Do ponto de vista antropológico, a sua indeterminação se dá em função da inconstância do homem que proporcionou o surgimento do humano arbítrio através do senso comum, a imaginação e a engenhosidade, para estabelecer regras, normas, ritos, costumes etc.

\footnotetext{
${ }^{77}$ Platão, Crátilo, [Cf. tp. VII,, § 388 a-c, p. 108-109].
} 
Temos aqui, portanto, duas interfaces que se coligam necessariamente através da ausência ${ }^{78}$ enquanto elemento de co-relação entre a linguagem e a história, pois tanto a linguagem não comporta significados unívocos, como a história constituída por fatos múltiplos, diversos e casuais, não comporta simetrias em sua contingencialidade.

Muito apropriadamente Angela Isoldi nos diz:

"Que a síntese da filosofia com a filologia possa parecer contraditória, como a síntese de razão e autoridade, isto reflete simplesmente a contradição da síntese do humano e divino, sem a qual, para Vico, não haveria história. A nossa realidade histórica e civil testemunha esta síntese, e isto é o fundamento da nossa verdade, mas nós podemos só descrevê-la na sua bi-valência, não explicá-la e entendê-la, pois que esta explicação é a verdade de Deus. Por isto, parece-me necessário ter bem firme este quarto ponto: que seria alterar substancialmente o pensamento viquiano, querer optar por um ou por outro momento da contradição. Vico nos parece, mesmo, rígido no esforço de ter ligado os dois momentos, reconhecendo ambos necessários para compreender o mundo civil das nações na sua realidade histórica"79.

Para Vico, os primeiros homens, ainda em estado de dispersão, em contato com as intempéries da natureza, expostos aos trovões, tempestades, feras e todos os tipos de adversidades, começaram a manifestar a natural necessidade de fazer sinais como rumores, assobios e gestos, que

\footnotetext{
78 Ao contrário dos estruturalistas, a ausência não é a impossibilidade de se pensar a origem; pelo contrário, é a condição necessária para pensá-la. Caso não houvesse essa ausência, decerto a origem não poderia ser investigada, porquanto, sendo essa ausência origem passível de investigação pela ordem do certum, (pois, somente, o certum pode incidir sobre ela), a verossimilitude dos signos míticos nos proporciona respostas sobre os povos primigênios mediante a justificação; o que não quer dizer carência de elementos comprobatórios, mas, também, não quer dizer comprovação na ordem do verum., como podemos observar no Segundo capítulo desta tese tp, 2.4., A poeticidade mítica.

${ }^{79}$ Embora se coadune com a minha visão acerca da natureza da filologia, penso que Isoldi faz uma leitura nos moldes da concepção aristotélica, sem atinar para a peculiaridade que o pensamento viquiano comporta. Não se trata de uma contradição, mas de uma unidade na diferença, de um peculiar modo de conceber o conhecimento. Isoldi, A.M.J.[ Cf. G.B.Vico, La vita e le opere, conclusione, Cappelli, p.476, 1986]
} 
lhes permitissem interagir com o meio, e entre si, com "violentíssimas paixões" foram as primeiras vozes humanas que emergiam impetuosamente das emoções; depois vieram os pronomes quase todos monossilábicos, com os quais, na ausência das palavras, se indicavam as coisas.

Essa tese, decerto, provocou perplexidades e contumazes reações, pois, para os doutos da época, a lógica racional cegava-os, não permitindo aferir a fantasia, a qual, resgatada por Vico como faculdade criativa, permitiu aos primeiros homens desenvolver a linguagem, cuja primeira figura criada foi Zeus ou Júpiter ou ainda Ios, "rei e pai dos homens e dos deuses a expedir os seus raios", propiciando aos primeiros homens sentirem que os raios e os trovões eram sinais de Júpiter,

“que provém de "nuo", “acenar", que se disse "numen”, a "divina vontade”. Assim, "Júpiter comandava por acenos e tais acenos seriam palavras reais", e a natureza seria "a língua de Júpiter",... Atribui desse modo a Júpiter o temido reino do raio, razão pela qual é "rei dos homens e dos deuses". Deram-lhe dois títulos: optimus, significando fortíssimo, e maximus, pelo seu vasto corpo, que é o céu. Ele concedeu aos homens um grande benefício porque não os fulminou, dai o título de "soter" ou de "salvador", e veio também o de "estator" ou "detentor" porque tirou aqueles poucos gigantes de seus erros ferinos, os quais se tornaram mais tarde os príncipes das gentes". 81

Nasceu, assim, Júpiter na poesia, assumindo um caráter divino, ao qual todas as civilizações gentílicas reduziam todos os auspícios. Desse modo, desenvolveram os homens primigênios a sabedoria poética, isto é, "sábios que entendiam o falar dos deuses concebidos como auspícios de

\footnotetext{
${ }^{80}$ Ibidem, [Cf. Secção Quarta - Do Método, § 340, p. 181;Ei, p. 239; Secção Primeira - Metafísica Poética, cap. I, Da metafísica poética, que nos dá a origem da poesia, da idolatria, da adivinhação e dos sacrificios, § 377, p. 214; Ei, p. 264].

${ }^{81}$ Ibidem, [Cf. Secção Primeira - Metafísica poética, cap. I, Da Metafísica Poética, que nos dá a origem da poesia, da idolatria, da adivinhação e dos sacrifícios, § 379, p. 217; Ei, p. 266-267].
} 
Júpiter" e, por isso, foram chamados de "divinis", no sentido de "adivinhadores", de "divinari", que propriamente é "adivinhar" ou "predizer".

A emergência da sabedoria poética dá-se por meio do "impossível crível" que proporcionou aos homens primigênios, enquanto "infantes" da primeira idade, ou seja, da idade dos deuses, desenvolverem tal sabedoria e estabelecer os fundamentos das civilizações.

A Filologia, tão bem empregada por Vico, forneceu-lhe o rumo pelo qual ele entendeu como foi possível ao homem erigir-se e desenvolver-se desde os primórdios. Sendo a ciência do "certum", a filologia permitiu extrair determinados princípios estabelecidos nas suas Dignidades ou Proposições referentes à Metafísica e à Lógica poéticas.

É interessante notar em Vico que a fantasia está naturalmente aderente ao corpo. O corpo assume uma vital condição para a emergência do conhecimento, através dos sentidos, que ao homem primigênio foram de importância vital para se desenvolver.

O senso comum, por exemplo, não é visto como juízo abstrato, senão como juízo sem reflexão alguma, comumente sentido... ${ }^{82}$, portanto fundado sobre o instinto, o hábito, e o costume, sendo também uma predisposição que propiciou aos infantes agir e reagir na natureza e, ao agir, conhecê-la, realizando desse modo um dos conceitos fundamentais da Scienza Nuova, o verum ipsum factum convertuntur, enunciado e desenvolvido anteriormente no De ant. como acima discorremos, e a partir do qual o homem age ao conhecer e conhece ao agir.

"Ideias uniformes, nascidas no seio de povos inteiros desconhecidos entre si, devem possuir um fundamento comum de verdade"

“...- tendo este mundo de nações sido certamente feito pelos homens (que é o primeiro princípio indubitado que se colocou aqui acima) e, por isso, devendo-se descobrir o modo dentro das modificações da nossa própria mente humana...; porque, quando acontece que quem faz as

\footnotetext{
${ }^{82}$ Ibidem, [Cf. Secção Segunda, Dos Elementos, tp. XII, § 142, p. 111; Ei, p. 179].

${ }^{83}$ Ibidem, [Cf. Secção Segunda, Dos Elementos, tp. XIII, § 144, p. 111; Ei, p. 179].
} 
coisas é o mesmo que as narra, não pode aí ser mais certa a história. Assim esta ciência procede precisamente como a geometria...,; mas com tanto mais realidade quanto mais a têm as ordens referentes aos assuntos dos homens...E isto mesmo é argumento de que tais provas sejam de uma espécie divina, ó leitor, proporcionar-te um prazer divino, porquanto em Deus o conhecer e o fazer são uma mesma coisa"

O homem primigênio realiza a história e, ao realizá-la, também a conhece, porque é resultado de sua própria criação.

Vico, ao lançar mão do instrumental filológico, reconhece a possibilidade de reconstituir a história da humanidade através da linguagem. O que nos causa certa perplexidade é o fato de que ele soube inferir muito bem, a partir da filologia, as consequiências de seus argumentos, no sentido de implementar uma nova ciência ${ }^{85}$ em contraposição ao status quo de sua época - como acima comentamos acerca do cartesianismo - que o deixou num certo isolamento e, decerto, malvisto pelos doutos da época.

No De constantia philologiae, Vico fornece uma definição bastante ampla acerca da natureza da filologia que, pertencendo à ordem do certum, tem um procedimento incerto, no sentido de que não procede de forma exata, porque se apóia em elementos cuja abrangência resulta da própria condição do fazer humano nas suas ações históricas e lingüísticas. Sua exatidão não se reporta ao cálculo matemático, mas refere-se ao contexto histórico, ao surgimento dos falares, às primeiras vozes, aos primeiros cantos, às primeiras articulações de sons. Na Opere Giuridiche , Vico apresenta pela primeira vez, de forma inequívoca, a importância do método filológico nas suas primeiras investigações.

O que seria de fato a filologia para Vico? Croce, acerca dessa questão, afirma:

\footnotetext{
${ }^{84}$ Ibidem, [Cf. Secção Quarta, Do Método, § 349, p. 187; Ei, p. 245].

${ }^{85}$ Essa colocação não se refere à obra, mas à sua concepção.
} 
"A pouca clareza sobre a relação entre filosofia e filologia, a indistinção dos dois modos absolutamente diversos de conceber, a redução da filologia à ciência são conseqüências e causas da obscuridade que reina na Scienza Nuova" ${ }^{\$ 6}$

- Tal observação sobre Vico foi, improcedente, e, como tantos outros autores contemporâneos, não atinou para a grande contribuição que a filologia forneceu e guarneceu muitos pensadores, e, decerto, parece que desconsiderou o caráter incerto do certum, como discorremos acima.

\section{Para Vico}

"A filosofia contempla a razão, donde provém a ciência do verdadeiro; a filologia observa a autoridade do arbitrio humano, donde provém a consciência do certo. ",87

Graças à filologia que abrange tudo aquilo que depende do humano arbítrio em virtude do qual é dado o certum, Vico funda a perspectiva da história ideal eterna. Mas o que determinou ${ }^{88} \mathrm{o}$ arbítrio enquanto faculdade e o possibilitou foi o senso-comum amparado pela providência divina, que propiciou ao homem compreender os fenômenos e agir sobre eles. A ação do homem primigênio no ambiente hostil que o cercava o obrigou por necessidade a interagir com o meio no qual estava, havendo nessa relação o confronto com o mundo, com a natureza, o que proporcionou o fazer a história.

Duas são as partes que constituem a história: a fala e a coisa, que é a relação necessária para o desenvolvimento da mente dos povos gentílicos, pois da fala emerge a trama da história e com ela

\footnotetext{
${ }^{86}$ Croce, La filosofia di Giambattista Vico, [Cf. La strutura interna della Scienza Nuova, III, p. 37]

${ }^{87}$ Ibidem, [Cf., Secção Segunda, Dos Elementos, tp. X, § 137, p. 110; Ei, p. 178].

${ }^{88}$ Este determinar está no sentido de causa, pois no estado ferino prevalecia não a liberdade, mas a libertinagem, o estado desenfreado das paixões. O livre arbítrio emerge do senso comum, pelas percepções diretas e imediatas como fator de normatização da conduta humana.
} 
funde-se, permitindo, assim, divisar a origem e o desenvolvimento da linguagem e das línguas nas suas propriedades, usos e variações.

“A filologia é o estudo do discurso e a consideração que se dirige à palavra e que transmite a história explicando a sua origem e o seu desenvolvimento. De tal modo essa ordena a linguagem segundo a sua época, para compreender a propriedade, as variações e os usos. Mas, assim como a palavra corresponde à idéia da coisa, à filologia compete antes de tudo a tarefa de compreender a história da coisa. "89

A filologia comporta, portanto, em seus atributos um caráter histórico, tendo como subsídio a epigrafia, a numismática e a cronologia, sendo de grande eficácia sua aplicabilidade. Por isso, os filólogos que comentaram acerca da república, dos costumes, das leis, instituições, disciplinas, obras de gente e de povos, certamente foram os primeiros historiadores. Trataram com rigor esse método, pondo à luz os mais importantes testemunhos da antiguidade, para assim conduzir a interpretação acerca da linguagem e, por conseguinte, da história.

Segundo Vico, os filólogos cometeram dois erros que provocaram um grave equívoco:

"o primeiro, ao afirmar que a linguagem poética seria imprópria e que as locuções apropriadas como "nasci, vivere, mori, videre, audire, timeri, irisci" pertencem exclusivamente à oração prosaica, enquanto que "in luminis ora edes, caelestes ducere auras" (sob a luz, o vento comeu a beira e levou para o céu), ou: "spiritum regere artus, animam in auras recedere, rem oculos usurpare, auritas haurae vocis, gelu per ossa currere, sanguinem fervere circa praecordia" ( o espírito rege os membros, a alma sob o vento retira-se, os olhos vêem as coisas, os ouvidos

\footnotetext{
${ }^{89}$ Vico, Opere Giuridiche, [Cf. Parte seconda, La coerenza della filologia, cp. I, § 1, p. 386]
} 
ouvem vozes, o frio corre através dos ossos, o sangue ferve através das entranhas), são ao invés locuções impróprias dos poetas ${ }^{, 90}$

Partindo dessa falsa visão, o segundo erro dos filólogos foi estabelecer a separação dos mais antigos escritores em prosa, quase que no tempo de Homero, e muito mais de Hesíodo e de Orfeu, que haviam falado em língua própria, antes que aquela comum da sua gente e, sendo os poetas os primeiros fundadores das nações gentílicas, conduziram a sociedade civil.

"Por que, se os poetas verdadeiramente conduziram a sociedade civil, e o vulgo que vivia ferinamente nos bosques, como poderiam usar uma linguagem tão remota daquela vulgar, que a gramática estaria instituída para explicar-lhes?"91

A idéia de desenvolver uma ciência filológica move-se no rastro dos críticos do seu tempo, mas distancia-se dos filólogos que trabalham somente com a lógica e a razão, omitindo a história da escritura para descobrir a lógica poética. Vico, portanto, não leva em conta as razões gramaticais por si mesmas, bem como a peneiragem etimológica formal (ao relacionar o latim com o grego, por exemplo), mas desenvolve uma filologia crítica e humanística, apresentando-a como sermonis studium no sentido retórico humanístico.

\footnotetext{
${ }^{90}$ Vico, Opere Giuridiche [Cf. Il Diritto Universale, Parte Seconda, La coerenza della filologia, cp. I, § 21, p. 398]

${ }^{91}$ Idem, $\S 22$,
} 


\subsubsection{Homero e a Filologia}

Será que estaria Vico ignorando a verdadeira origem da poesia? Questiona-se:

"Se estas duas proposições são verdadeiras, do mesmo modo que são entre si contrárias, induzem-me a uma grave dúvida: se não estamos ignorando a verdadeira origem da poesia",92

Para esclarecer melhor essa dúvida ele busca nesse momento regular a filologia segundo a norma da ordem do certum e o trabalho de Simón Royo Hernandez no seu texto intitulado "Las fuentes escritas de Grecia"(2008) acerca da origem biológica das línguas, vem ao encontro da tese viquiana que nos ajuda a entender melhor a pesquisa que ele fez, bem como a estabelecer comparações pertinentes aos critérios empregado na sua scienza .

Segundo Hernandez,

“alguns hominídeos tinham um trato vocal similar ao do homem de 200 mil anos a.C., porém, provavelmente, não dispunham de um sistema nervoso suficientemente desenvolvido para controlá-lo", 93

tese esta do desenvolvimento mental dos homens primigênios, mais especificamente a respeito dos bestiones. Assim, também se constata que o sistema proto-indo-europeu ${ }^{94}$ provavelmente proviria da cultura Kurgan, que remonta a cinco mil anos a.C., Kurgan I, cidade situada ao sul da Rússia entre o rio Dnieper, o Caucaso e os Urales. Surgiu de uma população semi-nômade, que, segundo os

\footnotetext{
${ }^{92}$ Idem, § 23

${ }^{93}$ Hernández, Simón Royo, [Cf., Las Fuentes escritas de Grecia, Origem biológico de lãs lenguas, Antropologia Ideasapiens, p. 1, 2008].

${ }^{94}$ Todos os dados apresentados neste tópico são de Simón Royo Hernandez [Cf. Las Fuentes escritas de Grecia, texto retirado da internet]
} 
dados acerca desse povo, habitava a região das estepes no sul da Rússia por volta de quatro mil anos a.C. Seus membros são conhecidos como "kurganos" devido as suas práticas de sepultamento, pois kurgan em russo significa "túmulo"95, confirmando assim, o sepultamento como um dos primeiros elementos instituídos pelos primigênios.

A relação entre a língua e a história é siamesa, estão absolutamente interligadas, e a filologia viquiana desvela este percurso fornecendo dados necessários para a compreensão da gênese dos povos e da religião.

A língua grega seria um ramo indo-europeu que provém de uma única língua representada em muitos dialetos e com testemunhos que datam aproximadamente do séc. XIV a.C. As provas mais antigas de sua existência encontram-se nas inscrições descobertas em Cnosos e outros lugares de Creta, encontradas principalmente em tábuas de argila numa escrita silábica que foi identificada como grego em 1952. Tal período denomina-se do grego micênico para distingui-lo do posterior, o clássico, que data do séc. VIII a.C., época em que se começou a escrever textos no alfabeto grego, em especial os poemas épicos Ilíada e Odisséia. No entanto, o alfabeto mais antigo que se conhece é o semítico setentrional, que se desenvolveu na Palestina e Síria por volta de 1700 a.C., formada com 22 letras consoantes. Os alfabetos hebreu, árabe e fenício se basearam nesse sistema; ao redor do ano mil a.C., o mesmo alfabeto fenício serviu de modelo aos gregos que acrescentaram letras para as vogais; o grego, por sua vez, serviu de modelo para o etrusco aproximadamente por volta do ano 800 a.C., do qual derivam as letras do antigo alfabeto romano e, por fim, todos os alfabetos ocidentais.

A língua grega, apesar de seu desenvolvimento em vários dialetos, é uma língua indoeuropéia falada na Grécia provavelmente desde o terceiro milênio a.C. A cultura minóica, dois mil anos a.C., desenvolveu um sistema de escrita hieroglífica que foi posteriormente substituída por volta do século XV a.C. por um tipo de escritura cursiva denominada pelos lingüistas de linear A, “

\footnotetext{
${ }^{95}$ O sepultamento é uma das primeiras instituições estabelecidas por Vico em sua Sn44, criada pelos povos primigênios como a religião e o matrimônio.
} 
em algum momento, adaptou-se ao grego do séc. XV, a técnica da escrita, presumivelmente por obra dos escribas palacianos de Cnossos", segundo Hernandez. Os micênicos, que ocuparam Creta no século XIV a.C., introduziram a escrita linear $B$, uma escrita silábica que deriva da linear $A$ que foi utilizada até o desaparecimento dessa cultura por volta de 1200 a.C.. Em 1100 a.C. surge a escrita grega arcaica, época esta que representa a adoção do alfabeto fenício pelos gregos, e os fenícios haviam adotado o alfabeto cananeo. Nos meados do século IV a.C. o alfabeto jônico desvinculou-se de todos os alfabetos locais e converteu-se no alfabeto grego geral, o que deu origem a todos os alfabetos europeus. Dessa miscigenação entre as línguas resulta a miscigenação entre as culturas.

De acordo com dados arqueológicos, na Grécia a religião micênica provém de duas fontes diretas, a mitologia de raiz indo-européia e a mitologia pré-indo-européia.

Os cretenses adoravam as divindades terrestres e agrícolas, embora os invasores indoeuropeus de Micenas, conhecidos com o nome de aqueus, reverenciassem divindades celestes e pastoris; aqueles tinham um panteon com deusas da fertilidade, e estes haviam trazido para a Grécia deuses da soberania, resultando no sincretismo entre as duas culturas: a religião micênica que herdou de Creta o culto aos heróis e a configuração do mundo infernal.

Ao final do século XIII a.C. os territórios de influência micênica foram novamente invadidos pelos dórios, e com o seu estabelecimento realizou-se definitivamente a povoação da Grécia. O sistema mitológico grego estava mais desenvolvido na época em que se compuseram as obras de Homero e de Hesíodo (século IX-VII a.C.), que se constituíram como principais fontes da mitologia clássica.

O caráter genealógico e o cenário mitológico, aqui apresentados, aproximam-se da narrativa bíblica presente no livro do Gênesis acerca da história e linguagem, bem como da instituição da religião entre os povos que para Vico foram comuns na formação da humanidade. 
O poema homérico é objeto de análises e interpretações similares à que Vico desenvolveu na sua Scienza Nuova. Hernandez considera a composição dos poemas homéricos um legado que se estendeu por um longo milênio, desde a idade de bronze, que começou por volta de 1600 a.C., até ao final da chamada Idade Média grega, por volta do ano 600 a.C.. Porém, as fontes desse período são escassas; apesar dos poemas homéricos, contamos apenas com fragmentos da escrita linear B e com algumas referências egípcias e hititas.

Tal como Vico, Hernandez considera um grave erro postular, como fez Diels-Kranz ${ }^{96}$, Orfeu como primeiro autor, em vez de admitir os fragmentos órficos como uma recopilação; esse erro cometido por especialistas modernos dá a falsa impressão da existência de um autor que tenha escrito tais fragmentos. Em Aristóteles já se encontram presentes alguns temas teogônicos órficos que não foram considerados obras de Orfeu, mas de um poeta chamado Onomácrito.

Outros autores são cognominados de unitários, por considerarem que os dois grandes poemas homéricos foram obras de um autor chamado Homero. Até mesmo Friederich Nietzsche, ao ser nomeado catedrático de Filologia Clássica da Universidade da Basiléa, tratou em sua Lição Inaugural sobre a questão homérica (1869), e defendeu a personalidade de Homero:

“...precisamente em nossos dias realiza-se o experimento acuradíssimo de reconstruir os poemas homéricos sem o auxílio explícito da personalidade [do autor], como [se fossem] a obra de muitas pessoas... O individual é sentido e acentuado cada vez mais, a possibilidade psicológica de um único Homero é requerida cada vez mais com maior força...bem antes toda poesia, $e$ naturalmente, toda poesia nacional, precisa de um indivíduo singular mediador...Bem antes a maioria afirma que um projeto total de um poema como a Ilíada pertence a um indivíduo, e que este seria precisamente Homero" $"$.

\footnotetext{
${ }^{96}$ Hernandez,S.,R., [Cf. Las fuentes escritas de Grecia, La cuestión homérica:analíticos y unitários, p. 4 de 9].

${ }^{97}$ No entanto, em Homero e a filologia clássica, Lección Inaugural (1869), Nietzsche considera Homero enquanto juízo estético "o centro dos erros homéricos” [Cf. Homero e a Filologia Clássica, Nietzsche ].
} 
Entretanto, F.A.Wolf publicou seus Prolegomenas ad Homerum (1795) demonstrando a impossibilidade de que as obras atribuídas a Homero fossem realizações de um mesmo autor; essa posição chamada de analítica nega a existência de Homero, segundo a tese de que os poemas são compilações de escritos de diversas épocas e procedências. A posição de Wolf baseia-se nos seguintes pontos:

“a) a inexistência de Homero; b) os dois poemas não são obras de um mesmo autor nem pertencem à mesma época; c) os poemas não são obra de um autor pessoal e único, mas um conglomerado de contos originariamente independentes que através de sucessivas refundições deram lugar a poemas mais extensos e, lingüisticamente, são compostos de quatro dialetos diferentes (î̂nico, eólico e, em menor grau, arcado-cipriota e ático), constituindo-se numa língua artificial que muito provavelmente não foi falada". ${ }^{98}$

Esta tese coincide com a descoberta de Vico acerca de Homero e vem ao encontro da veracidade de suas análises, Sabemos que no Renascimento tal tese era conhecida. No entanto, Vico desenvolveu uma análise filológica que comprovou de forma minuciosa a inexistência desse personagem. Para Vico,

"Homero teria sido uma idéia ou um caráter heróico dos homens gregos, enquanto estes narravam, cantando as suas histórias" $" 99$

Já Simón Royo Hernández [Cf. Las fuentes escritas de Grecia, p.5] supõe o contrário. Sente-se no espírito do texto nietzscheano a relutância em não aceitar que Homero tenha sido um feixe de recompilações, ao mesmo tempo em que não consegue afirmar taxativamente que Homero tenha sido um autor, uma pessoa.

98 F.A.Wolf é citado por S.R.Hernandez no texto acima.

99 Ibidem, [Cf. Secção Segunda, Descoberta do verdadeiro Homero, Introdução, § 873, p. 644; Ei, p. 577]. 
A originalidade de Vico apóia-se numa vasta compilação documental, numa confirmação filológica e numa prova que justifica o sistema de proposições ou dignidades que comporta: princípios (princípios, elementos e método) e poéticas (sabedoria, metafísica, lógica, economia, política, história, física, astronomia, cronologia, e geografia), para a descoberta do verdadeiro Homero.

É intrigante perceber o modo como os filósofos cartesianos desqualificaram a doutrina crítica filológica enquanto instrumento de averiguação da linguagem, por conseguinte, da história. Relegaram a Imaginação enquanto elemento inconsistente para a formação da concepção mítica, e desprezaram o mito enquanto expressão de uma visão de mundo numa determinada fase da humanidade ${ }^{100}$.

Por isso Vico ressente-se dessa omissão por parte dos pensadores e pergunta-se:

“Por que os filósofos evitam os estudos filológicos? É justa esta atitude?”101

Em outra passagem, Vico pergunta?

"Descartes e Malebranche afirmaram que não conviria ao filósofo dedicar-se e aprofundarse na filologia;... por que o Crátilo de Platão não teve um êxito feliz? Que com grande esforço empenhado não logrou êxito?"; Ele mesmo responde:... "porque ignorou a língua certa introduzida pela primeira lei no tempo dos heróis-poetas; os jônios fundaram as repúblicas sob tais leis; ignorou porque no tempo das leis falavam a língua aos seus contemporâneos reformada como era de ano em ano pelos nomotetas "102

\footnotetext{
100 Ouso dizer que esse pré-conceito é filosoficamente cultural, advém com o socratismo, embora tenhamos em Platão o primeiro manual de filologia com o seu diálogo O Crátilo; porém, encontramos esparsas, em diversos diálogos, referências desdenhosas à concepção mítica, e o Livro Primeiro da Metafísica de Aristóteles é ilustrativo quanto a essa questão.

${ }^{101}$ Vico, Opere Giuridiche [Cf. Il Diritto Universale, Parte Sseconda, cp. I, § 24, p. 398]

102 Ibidem, [Cf., § 24- 25, p. 398,400].
} 
Para o resgate da história dos homens primigênios ou das nações gentílicas, Vico recorreu à história das coisas e das línguas. Esta é derivada daquela, já que as coisas precedem aos signos, enquanto a história da palavra, suas primeiras manifestações surgem com o mito. Já a mitologia ou história do tempo fabuloso não procede, enquanto fato, de nenhuma origem, nem numa sucessão certa, visto que o conhecimento das coisas no tempo obscuro é esparso e disperso.

\subsubsection{O corpo e o canto}

Os princípios da história não confirmados pela lógica da razão natural geraram obstinação e não ciência, mas deles decorre a história dos primeiros homens ou dos infantes, como Vico os designara, homens da era fabulosa, do falar poético, da poesia nata por natureza, das paixões que geraram fantasias vivificantes mediante a relação sensível e intuitiva, que com as coisas (raios, trovões, tempestades, escuridão, estrelas, o sol, a lua...) mantinham de forma visceral, siamesa, transosmótica, no tempo em que o homem e a natureza eram inseparáveis, e não iniciou tal história por um ponto irruptivo, mas numa temporalidade inalcançável, em outras palavras, numa gênese permanente, no dizer de Coseriu. ${ }^{103}$

O homem, primeiro ser em grau de gerar universais, forma fantasmas, e a linguagem nasce naturalmente através de gestos e grunhidos apaixonantes. Dirá Vico que a poesia tem por fim animar o inanimado, dar vida às coisas, e assim acreditou-se que o céu tonante fosse Júpiter, prodígios compostos de magia que operavam por encantamento. Nascido da ignorância, da incapacidade de articular, o saber nato surge com o Canto; por isso, os mudos ou os sem linguagem

${ }^{103}$ Conferir NR 162, II cap,. p. 108 
expressavam-se em sons que são cantos pela própria dificuldade de falar, e esse canto impetuoso era arrítmico e sem modulação, e da incapacidade de significar a coisa de maneira própria, isto é, pela discursividade, utilizavam a metáfora.

Vico, no entanto, considera o canto como irmã da linguagem gestual, sendo ele,

"o primeiro produto sematológico da voz, como o gesto é o primeiro produto sematológico do membro do corpo", como afirma Jürgen Trabant ${ }^{104}$

No corpo nascem as imagens materiais primordiais que são dinâmicas, ativas e estão ligadas à vontade simples, espantosamente rudimentar, pois é no corpo que se refletem os objetos circundantes, isto é, a ação que esses objetos exercem sobre ele. O canto é o veículo sígnico corporificado de ultrapassagem do real enquanto expressão significante através do falar cantando ${ }^{105}$. O canto superaria dois obstáculos de articulação: um obstáculo físico e outro psíquico. No primeiro caso, os órgãos do corpo predestinados à produção vocal, e no segundo caso à "psiquê", que não estaria devidamente pronta, ainda estaria dominada pelas paixões, e o canto proporcionaria a possibilidade de superação.

Para Vico, o canto determina o poder mimético da produção sonora, pois a conaturalidade nos tempos mitopoéticos instaura-se entre a palavra e o cosmos e configura-se em interjeições, onomatopéias, metáforas, metonímias e fábulas antropomórficas. A linguagem originária, que pelo uso de mímeses e semelhanças animava toda a natureza e dela fazia um vasto corpo, foi a condição para o desenvolvimento da humanidade. O canto não só exprime a sensibilidade, mas representa

\footnotetext{
${ }^{104}$ Trabant, Jürgen, Grido, canto, voci, [Cf. 4. Canto e grido, Laboratorio dell'ISPF, ISSN 1824-9817, II, 2005, I, p. 27].

105 A tribo primitiva dos índios Pirahãs reúne-se de cócoras e conversam através de assobios: “Outra peculiaridade dos Pirahã é que, apesar de resumida e difícil comunicação com os civilizados, eles geram qualquer palavra através da música, assobio e até falar com a boca fechada ou cheia com alimentos, destacando-se que as notícias importantes entre eles são dadas de forma cantada”, informou Ulisses Lima. Os índios podem usar esses recursos com vogais e consoantes juntas, cantando, cantarolando baixo ou assobiando conversas inteiras. Um artigo sobre a tribo Pirahã, descrevendo a descoberta de Everett, foi publicado na última edição da revista americana The New Yorker.
} 
também o mundo. Temos já visto quais são os primeiros cantos, dos quais fala Vico: "são os nomes de Deus máximo: Ios, Zeus e Ur”. Esses cantos imitam o som e o relâmpago, seu surgimento natural, por isso são cantos e não gritos.

A etimologia do verbo "cantar" para Vico provém de canere que significa "predizer" e haveria de fazer-se com os auspícios. Por isso, Apolo, deus do canto, puniu Mársias e Lino ${ }^{106}$, os quais, como melhores cantadores, duelaram com o deus e foram vencidos e punidos. Mas o fascínio do canto é proporcionar ao outro a escuta, o saber escutar. Sendo o canto a primeira semiose fônica, seu influxo deixa o outro encantado pela expansão, modulação, sonorização, rumorização de múltiplas tonalidades balbuciantes que fluíam, propagando-se no espaço, ecoando no labirinto auricular, promovendo a formação dos primeiros sinais de comunicação.

Em todas as línguas do mundo a maior parte das expressões em referência às coisas inanimadas faz-se mediante o corpo como veículo dos humanos sentidos e das humanas paixões, conforme podemos observar:

“cabeça”, por cima ou princípio; "frente”, "costas”, adiante e atrás; "olhos” de videiras e aqueles que se chamam "luzes" ingrediente das casas; "boca”, toda abertura; "lábio", bordo de copo ou de outra coisa; "dente" de arado, de ancinho, de serra, de pente; "barbas", as raízes; "língua" de mar; "gargantas" ou "embocaduras" de rios ou montes; "colo" de terra; "braço" de rio; "mão" por pequeno número; "seio" de mar, o golfo; "flancos" e "lados", os cantos; "costas"

\footnotetext{
${ }^{106}$ Bulfinch, em seu "O livro de ouro da mitologia", apresenta a punição de Lino desferida por Hércules e a de Mársias por Apolo.[Cf. p. 232 da 26 edição]. Junito Brandão, [Cf. Dicionário mítico-etimológico, volume.II, $3^{\text {a }}$ edição, p.62], apresenta uma variante beócia do mito: Lino é filho de Anfímero e de uma das musas, Urânia, Calíope ou Terpsícore. Cantor excelente desafiou Apolo para um certame. O deus, irritado, o matou a flechadas. Outra variante diz que Lino tenha sido professor de canto de Héracles, e um dia, chamado a atenção pelo mestre, num assomo de raiva pegou uma pedra enorme, outros dizem um tamborete ou lira, e deu-lhe uma pancada tão violenta, que o mestre foi acordar no Hades. Entretanto, o mais importante de tudo isso é a beleza e o encanto que o canto proporcionava deleitando seus ouvintes, deixando-os atentos, isto é, o prazer de escutar o outro. Tal é a importância que tinha o canto para os povos divinizantes/divinários quanto heróicos, que Virgílio na sua Quarta Écloga(55-57) reúne os dois grandes poetas músicos e místicos: "Ninguém há de me sobrepujar com seus cantos/nem Orfeu da Trácia, nem tampouco Lino, embora assistidos/um por sua mãe, outro pelo pai: Orfeu por Calíope, Lino pelo famoso Apolo".
} 
de mar; "coração", pelo meio (que "umbilicus" era dito pelos latinos); "perna" ou "pé” por fim; "planta” para base, ou seja, fundamento; "carne”, "ossos” de frutas; "veio” de água, pedra, mina; "sangue" das videiras, o vinho; "vísceras" da terra; "ri" o céu, o mar; "assobia" o vento; "murmura" a onda; "geme" um objeto sob um grande peso; e os camponeses do Lácio diziam "sitire agros", "laborare fructus", "luxuriati segetes"; e os nossos camponeses ficarem de amor às plantas, “ficarem loucas as vinhas”, “chorarem os regos",107

Assim, o homem fez-se regra do universo e, por essa via, Vico circunscreveu sua tese compondo e articulando os argumentos que provieram de sua compreensão poética, ou ainda de sua fantasia reminiscente $^{108}$ e de sua pesquisa, mediante o topos sensibile que tão bem manejava, e da crítica filológica, cujo método possibilitou o resgate da concepção mítica ao prover a Scienza Nuova de uma base investigativa minuciosa de dados que lhe forneceram material para a confirmação de suas hipóteses acerca da história da humanidade, e em particular do mito, que foi promissor nas suas investigações e nas suas descobertas.

“assim nos é agora naturalmente negado poder entrar na vasta imaginativa daqueles primeiros homens, cujas mentes em nada eram abstratas, em nada eram subtis, em nada espiritualizadas, porque estavam todas imersas nos sentidos, todas reprimidas pelas paixões, todas sepultadas nos corpos: pelo que dissemos acima que agora apenas se pode compreender, não se podendo completamente imaginar, como pensariam os primeiros homens que fundaram a humanidade gentílica"109

\footnotetext{
${ }^{107}$ Ibidem, [Cf. , cap. Segundo, Corolários acerca dos tropos, monstros e transformações poéticas, § 405, p. 240; Ei, p. 284].

${ }^{108}$ Esse conceito é desenvolvido no terceiro capítulo desta tese.

${ }^{109}$ Ibidem, [Cf. Secção Primeira - Metafísica Poética, cap. I, Da metafísica poética, que nos dá a origem da poesia, da idolatria, da adivinhação e dos sacrfícios, § 378, p. 215-216; Ei, p. 265].
} 
A crítica filológica empregada por Vico permitiu que ele pudesse resgatar a história da humanidade nas suas origens levando em consideração o mito, que, por muitos desprezado, forneceu as bases para uma compreensão mais clara e distinta acerca da história que começa certamente com a linguagem dos homens primigênios, ou das nações gentílicas na era dos deuses.

Vico demonstra a possibilidade de se desenvolver uma investigação séria e rigorosa com o intuito de salvaguardar o modo pelo qual se pode fazer ciência a partir de princípios que conferem coerência e legitimidade aos procedimentos utilizados para o desvelamento da origem da história e, por conseguinte, da origem da humanidade. Mas não somente a filologia, também os tropos e os topos constituem elementos de cientificidade para a consecução de sua obra, combinando retórica enquanto instrumento de comparação e crítica filológica enquanto método de investigação.

Ernan Mc Mullin ${ }^{110} \mathrm{em}$ seu ensaio sobre La teoria vichiana della Scienza, aborda a questão do método na Scienza Nuova, que sem dúvida é profícuo e pertinente pelo confronto que estabelece, procurando demonstrar a fragilidade epistêmica que rege a obra de Vico, ao estabelecer uma relação entre as diversas garantias (axiomática, indutiva e retrodutiva), partindo do princípio que as Dignidades deveriam ser entendidas como axiomas no rastro do princípio do verum factum, já que conhecemos o que fazemos. Então, as Dignidades seriam axiomáticas e, por isso, não precisariam de confirmação, pois são evidentes por si mesmas, segundo ele. Ora, as Dignidades não são axiomas, mas proposições que norteiam a compreensão e sistematização das doutrinas, asserções que promovem suporte teórico e conexões argumentativas.

Conforme dissemos acima sobre a natureza da Filologia, faz-se necessário pensar a doutrina viquiana como uma nova forma de leitura do mundo das nações, de um novo método que tem como base o verossimilhante, portanto, contém no seu caráter e na sua constituição, formas diferenciadas das criadas e definidas, seja por Aristóteles, seja por Euclides. É importante perceber que Vico professa peculiarmente uma nova visão de ciência que dê conta das variáveis incertas constitutivas

\footnotetext{
${ }^{110}$ Leggere Vico, Giorgio Tagliacozzo e di altri [Cf. La teoria vichiana della Scienza, Ernan Mc Mullin
} 116]. 
da linguagem, da história e do mundo das nações. Sem isso, vamos cair numa falsa visão hermética e dissociada da crença do certum viquiano que apreende o processo histórico da humanidade na sua complexa dinamização, sem se ater a um rigor calculista e mensurável que é incapaz de compreender aquilo que de fato compõe a dissimetria humana, a sua controvertida atitude e comportamento que fazem do homem um ser inconstante.

Daí a importância decisiva que Vico atribui à imaginação como faculdade primeira no desenvolvimento do conhecimento humano, pela capacidade de agregar imagens por meio do engenho que originariamente se constituiu no modo de apreensão dos homens primigênios através da intuição pela via do senso comum. Processo este que até hoje a ciência utiliza e realiza, posto que o princípio geométrico norteador da pesquisa nada mais é que uma admissão, uma suposição, um processo mental que envolve a imaginação como elemento de captação de um suposto fato que necessita de comprovação, ou seja, a hipótese científica ${ }^{111}$ (suppositio naturalis), enquanto aplicação do raciocínio geometrizante, enquanto instrumento metodológico para a investigação dos dados da experiência. "Muitas hipóteses parecem ocorrer num relâmpago de intuição"112. Significativa afirmação metafórica que descreve um modo imaginativo de apreensão de um momento. $^{113}$

Ousamos pressupor viquianamente que o conhecimento produzido pelo senso comum, e até mesmo pela ciência (uma vez que as teorias científicas são provisórias e as condições de experimentação são ideais, isto é, em laboratórios), contém no contingencial da realidade, na qual o

\footnotetext{
${ }^{111}$ Destaque em negrito.

112 G.F.Kneller, A ciência como atividade humana [Cf. "Um método de investigação", Raciocínio e formação de hipóteses, p.112].

113 Tantos outros epistemólogos e empiristas lógicos consideram que a formação de hipóteses é fundamentalmente não-racional. Segundo Moles, o raciocínio criador da ciência, embora rigorosamente determinado, contém um aspecto arbitrário irredutível: "1. arbitrário na escolha dos métodos heurísticos; 2. arbitrário na escolha do assunto, que é muitas vezes uma conseqüência do anterior; 3 . arbitrário nas conexões infralógicas, associações de idéias etc...; 4. arbitrário para mais ou para menos nos próprios processos de utilização ou de percurso da rede racional; 5. arbitrário, enfim, na demonstração". Vico descreve o passado de forma seletiva buscando no material disponível, como a numismática, a epigrafia, a cronologia e as fábulas, o que há de mais significativo e relevante para a sua teoria, combinando, assim, imaginação e dados. [Cf., Moles, A., A Criação científica, Filosofia da Ciência, As fontes profundas da criação científica, § 1. Arbitrário e margem de incerteza na psicologia da criação, cap. 9, Ed. Perspectiva, São Paulo, 1981, p.239].
} 
homem está inserido, uma dinâmica adversa que não comporta qualquer exatidão, mas tão somente probabilidades, visto que a realidade na sua congênita mutabilidade é incerta por natureza.

Demonstra-se, assim, a originalidade do pensamento viquiano, no qual o conhecer é a conversão do verdadeiro no fato (substituindo o critério da percepção clara e distinta de natureza matemática), singularmente original entre outros conhecimentos humanos, arrojado pela iconoclastia de seu princípio, rigoroso pelo índice de verossimilhança como critério investigativo, admirável, e capaz de influenciar e transformar o restante do saber humano, pois o verossímil está entre o verdadeiro e o falso que emerge do senso comum. Por fim, a imaginação, a intuição, a experiência, a probabilidade e a autoridade daquela forma de pensamento, que emerge do senso comum, universal a todo o gênero humano por seu livre arbítrio, são elementos constitutivos de uma nova ciência, de uma nova visão de mundo. 


\section{CAPÍtUlo II}

\section{A ESTRUTURA CONCEITUAL}

Abordaremos neste capítulo, os conceitos fundamentais da concepção viquiana, desenvolvida segundo o modelo do De ant., no seu Libro Primo, Metafísico ${ }^{114}$, aonde ele faz um apanhado riquíssimo dos vários conceitos que irá nortear a sua obra maior a Scienza Nuova 44 . Valendo-nos dessa forma empregada por Vico, elencamos os conceitos fundamentais, estabelecendo suas correspondências ao longo da tese, através de notas de referência, permitindo as remissões inter-textuais, formando uma cadeia, cujos elos, nos proporcionam a clarificação e a conexão entre as partes recorrentes.

\subsection{O verum factum}

No capítulo precedente observamos a inusitada concepção inaugurada por Vico na sua Scienza Nuova marcada de forma indelével pelo humanismo, diria absoluto, pois nesta obra fundase a ciência do homem no devir da história, porque ele é seu autor, ele a faz, ele a conhece. Como diz Pasquale Soccio:

“Quanto à historiografia, foi o próprio Vico que percebeu a dimensão total do humano na história com indiscutíveis motivos de originalidade através da nova metodologia derivada de sua genial intuição ". ${ }^{115}$

\footnotetext{
${ }^{114}$ Vide na Introdução NR a pg. 12.

${ }^{115}$ Vico, Autobiografia,Poesie, Scienza Nuova [Cf. L'alterna fortuna di Vico, F. De Sanctis, p. LII].
} 
História conjugada pela diversidade, pela diferença e pela complexidade que comporta as variações das ações humanas que poderiam ser entendidas somente a partir de uma visão que desse conta da diversificação e do indeterminismo que conforma o movimento histórico, embora o forme na diferenciação de suas idades. Nessa perspectiva, todos os elementos que compõem o fazer humano (linguagem, concepções, instituições, hábitos e costumes) são coordenados por este fazer e conhecer diverso, múltiplo e incerto, fruto de contingências, paixões, perplexidades e contradições que compõem a natureza humana na sua essencialidade naturalmente mutável, como podemos observar no $§ 1106$ em que traça a diversidade entre os povos primigênios e a primeira barbárie dos sentidos com os povos da malícia reflexiva ${ }^{116}$

A concepção viquiana arrojada e ousada pela divergência e pelo novo modo de pensar que rompeu de vez com a racionalidade cartesiana, definiu-se pela contraposição ao pensamento desenvolvido por meio de parâmetros mensuráveis como o verdadeiro e o falso. No entanto, pensar o indeterminado, o provável, o verossimilhante, dando realce não à razão, mas à imaginação enquanto disposição da mente para a criação e para o conhecimento propiciados por outros elementos ideais conjugados entre si, como o conatus, o engenho, o senso comum, o livre arbítrio e outros que lhe são subsidiários, permitiu a Vico conceber o mundo na sua diversidade tendo como ponto de partida o princípio do verum factum $^{117}$.

Como Vico conjugou tais elementos? Como derivou esses conceitos? Que concepções remodelou para chegar a um novo modo de pensar?

Basicamente estes são os pressupostos que vamos trabalhar para demonstrar a proeza que Vico empreendeu, fazendo de seu modo de pensar a matriz de sua teoria, conformando-se a ela, e nela subsistindo, pois a sua formação enquadra-se no período de uma cultura que caracterizou-se por interesses notadamente científicos e matemáticos de inspiração galileana, gassendista e cartesiana.

\footnotetext{
${ }^{116}$ Vico, Ciência Nova [Cf. Conclusão da Obra, Sobre uma eterna república natural, optima em cada uma das suas espécies, ordenada pela divina providência, § 1106, p. 841; Ei, p. 704].

${ }^{117}$ Destaque em negrito
} 
O primeiro momento, diríamos, de sua indagação filosófica parte do princípio verum factum que reconduz ao conhecer per causas, fundado sobre a convicção da finitude do conhecer humano, cuja gnosiologia buscará uma síntese entre a tradicional teoria adequacionista ${ }^{118}$ do conhecer e a nova consciência crítica da necessidade de fundar o conhecimento sobre a experiência. A partir daí, Vico desenvolverá o mais significativo, profundo e revolucionário princípio que perpassará toda a sua especulação. Ele percebeu a exigência de demonstrar no homem a limitação de sua consciência, de sua finitude, excluindo a possibilidade que o homem teria racionalmente de coincidir com Deus enquanto essência formal da coisa, ou que poderia operativamente penetrar na lei da natureza para possuir e dominar a natureza como pretenderia Galileu, Bacon e Descartes. Entretanto, a sua maior polêmica será o confronto com o cartesianismo que buscou inserir a particular racionalidade humana na infinita racionalidade divina. Vico, a partir daí, confrontará, a justificação da positividade do finito, com a fragilidade epistêmica do Cogito cartesiano.

Para Descartes tratava-se de encontrar a ligação gnosiológica entre a evidência humana da consciência e a idéia de Deus, buscando fundar a demonstração da existência de Deus no processo da consciência humana. Galileu e Bacon preocupavam-se em estabelecer a incidência do processo gnosiológico humano na realidade lógico-ontológica de Deus, seja através da matemática, seja através do processo das leis naturais.

Vico conduzirá a interpretação do verum factum como possibilidade de uma Scienza Nuova que conjugada à posição da teologia católica adequacionista definirá o significado do verum et factum convertuntur no âmbito da realidade divina, ou seja, como poderia realizar-se em Deus a perfeita coincidência do fazer com o conhecer? O homem não poderia sabê-lo, mas poderia aproximar-se do significado desta coincidência em relação com aquela da verdade revelada.

\footnotetext{
${ }^{118}$ Doutrina escolástica, que afirma que a idéia possui uma correspondência exata com a própria natureza da coisa, objeto da idéia: adaequatio rei et intellectus. As fontes da gnosiologia viquiana segundo Croce seriam, o nominalismo scotista, neo-platonismo do Renascimento, bem como, Ficino, Scoto, Occam, Nicolau de Cusa, Campanella, Cornelio, Leonardo di Capua entre outros, [Cf. Croce, B., Le fonti della gnosiologia vichiana, in Saggio sullo Hegel, Bari, 1913, p. 241-267].
} 
O primeiro problema que surge para Vico estaria na sua interpretação de Deus Primeiro Fazedor, pois haveria de distinguir Deus criador da sua criatura, já que o entendimento divino coincide com o seu fazer, com a sua criação. E sendo as coisas co-eternas ${ }^{119}$ na mente de Deus, a sua verdade sobrevém por Deus somente no ato de sua criação.

"Daqui se pode conjecturar que os sábios antigos da Itália se convenceram acerca da verdade pelas seguintes proposições: a verdade se identifica com o fato; por conseqüência a primeira verdade está em Deus, porque Deus é o primeiro fazedor; essa primeira verdade é infinita, enquanto fazedor de todas as coisas; é completíssimo, pois que representa a Deus, enquanto contém, os elementos extrínsecos e intrínsecos das coisas"120

Para resolver esta problemática da coincidência, Vico desenvolverá a distinção entre o fazer ad intra e o fazer ad extra, entre o fazer gerativo e o fazer criativo. O fazer gerativo resguarda a própria divina entidade, o fazer criativo resguarda a realidade da coisa; sendo o primeiro $a b$ eterno, portanto um verdadeiro incriado; e o segundo dar-se-ia no tempo, seria constituído no tempo e por isso um verdadeiro criado.

A distinção entre estes dois atos resguarda a transcendência divina acerca da coisa, mas ainda não resolve a problemática. A dificuldade que poderia parecer resulta das diversas adjetivações entre criado e gerado, pois incide na comum determinação de verum atribuido tanto ao gerativo quanto ao criativo. O verdadeiro gerado é de fato Deus como Mente pura, Sapiência, Verbo, e é nesta sapiência que vive a verdade, e é desta, que toda a verdade, também aquela criada, alimenta-se.

\footnotetext{
${ }^{119}$ Co-eterno é tudo aquilo que já é em Deus, porque Ele é absoluto e, no ato da criação as coisas acontecem porque Ele as faz. Ele é o intelecto divino que contem todos os elementos para a sua criação. ${ }^{120}$ Vico, De ant., [Cf., Lm, cap I, Il vero e Il fatto, p. 62].
} 
"A Sagrada Escritura, com elegância verdadeiramente divina, chamou "Verbo" (Verbum) a sapiência de Deus, que contém em si a idéia de todas as coisas, e ainda os elementos de todas as idéias. No Verbo de fato identificam-se o verdadeiro e a compreensão de todos os elementos que compõem a totalidade do universo; se quisesse poderia constituir infinitos mundos; $e$ já que na sua divina onipotência conhece tudo isto, existe um Verbo real exatíssimo que sendo toda a eternidade conhecido pelo Pai, toda a eternidade é ainda gerada por ele"121

Essa passagem é importantíssima para verificar a dificuldade na qual Vico se viu implicado, pois o Verbo conhecido e gerado ab eterno, co-essencial ao Pai, é o verdadeiro incriado, mas a esta eterna e atemporal geração não se pode atribuir um fazer no significado essencial de conter e dispor ordenadamente os elementos intrínsecos e extrínsecos da coisa, pois o verdadeiro é próprio do fazer, pelo qual o Verbo se revela como Sapiência, Mente pura, que conhece fazendo e faz conhecendo numa composição de elementos idealizados, dos quais surge a realidade, ato de sua criação. Se a fórmula do verum et factum convertuntur é válida, tanto o Verbo co-eterno ao Pai pode ser Sapiência e Mente pura enquanto se articula no verdadeiro criado que se funda sobre o fazer criativo, e também, a realidade do Verbo na sua eternidade deve ser originariamente Sapiência e não pode atingir tal qualificação sucessivamente à sua geração; o mesmo Verum criado deve ser co-essencial ao Verbo, ao seu ser Verum. Entretanto, a partir dessa tese entram em cena duas posições católicas: a voluntarista e a intelectualista; aquela, antecipa o ato gerador da divina vontade ao entendimento que é o Verbo: tanto Deus entende quanto quer entender; e esta, vê na realidade mental do Verbo a fonte ideal do seu fazer: tanto Deus quer, quanto sabe. Tanto num caso como no outro, fragmenta-se a fórmula verum ipsum factum num ato de volição que condiciona a

\footnotetext{
${ }^{121}$ Ibidem., [Cf. Lm, cap. I, Il vero e Il fatto, p. 64].
} 
Sapiência, isto é, numa antecipação do ato mental puramente contemplativo em relação a articulação do fazer. ${ }^{122}$

Percebemos a necessidade do auxílio teológico para a compreensão conceitual do princípio viquiano que de certo modo é subvertido; porquanto, Vico apresenta a sua fórmula como síntese entre essas duas posições abrindo caminho através do conceito de criação.

A indissolúvel ligação entre o verum da Mente divina e o fato da divina criação é explicitamente reconhecido por Vico através do esforço de identificar e junto distinguir a forma física e a forma metafísica, que como veremos dará origem a teoria viquiana dos pontos metafísicos e do conatus.

Para solucionar tal problemática, Vico na sua engenhosidade buscou uma via que pudesse prover o homem com a mesma fórmula atribuída a Deus. Tal via corresponde ao conceito de bondade, pois a providência divina em sua magnanimidade infinita proveu o homem de tais atributos por ser infinitamente Bom. Quando o verdadeiro converte-se em fazer como ocorre em Deus, isto é, quando o operar da mente é o operar real, o fato seria necessariamente bom. Desse modo ocorre em Vico a superação do confronto da existência. Todo existente enquanto nasce do fazer divino que é essencialmente Verum, enquanto é criatura de um ato mental capaz de tornar-se real, não apenas essencial, mas também existencial, é bom.

Isto que vale para todo o existente, vale também para o homem que em todas as manifestações da sua existência deve ser considerado bom, ou seja, essencialmente positivo. Este

\footnotetext{
${ }^{122}$ Angela Isoldi nos dá uma explicação apropriada da relação entre a doutrina católica e o conceito central da Sn44, o ipsum verum factum convertuntur que clarifica esta condição entre o fazer e o conhecer, a criação e o co-eterno em Deus. Segundo ela, "Vico adota uma fórmula de verdade totalmente vinculada à tradição católica para justificar amplamente uma interpretação neste sentido. De outra parte o desenvolvimento e a aplicação desta fórmula viquiana são tais que revelam o significado particularíssimo que Vico lhe atribui e para dar pretexto também àquela assonância imanentista que os idealistas acreditam encontrar. Na realidade Vico quer realizar com esta fórmula uma perspectiva sintética da verdade, real e mental, humana e divina, cognoscitiva e operativa. O fazer do qual Vico fala é sem dúvida um fazer mental, porque é a mente que realiza a continuidade entre o homem e Deus, é a mente que, como princípio ordenador da existência humana, constitui a verdade desta. Mas, próprio porque esta realidade mental testemunha a indestrutível troca entre o homem e Deus, no seu fazer não pode haver um limitado valor gnosiológico, seja isso entendido no sentido realista ou no sentido formal. A validade do ato mental não nasce da sua comparação com uma realidade dada, seja esta física ou divina, mas da possibilidade de fazer surgir daquele ato uma real existência. O fazer mental é verdadeiro enquanto é criador". [Cf. G.B.Vico, La Vita e Le Opere, Conclusione, p. 471-472, Cappelli, 1986].
} 
reconhecimento em Vico terá uma importância fundamental na aplicação positiva do verum factum ao conhecimento humano.

"Para dizer em uma palavra, o verdadeiro converte-se com o bom, quando isto que é conhecido como verdadeiro obtém o seu ser também da mente que o conhece

A mente humana comporta tal bondade e tal positividade em sua limitação, em sua finitude, não sendo, portanto, o fazer humano uma criação absoluta, mas restrita, que encontra os seus limites de um lado na transcendência da essência racional divina, posto que dela participa, mas com ela não se identifica ${ }^{124}$; de outro, o mundo físico enquanto obra da Mente divina não pode ser entendido pela mente humana.

Sendo a providência divina onisciente, tem por finalidade a sua imensa bondade, pois tudo o que ela dirige e ordena é sempre em vista de um bem superior àquele dos homens, mesmo que este homem na sua primigênia idade vivesse da deplorada obscuridade dos princípios e nas inumeráveis variedades de costumes, os benefícios divinos ao conduzir o gênero humano para o bem, conservando-o em sociedade, demonstra a eterna bondade de Deus ${ }^{125}$.

\subsection{O conatus}

Explicitado o conceito de verum- factum examinaremos a noção de conatus enquanto movimento que se dirige para um determinado fim positivo. Deste ponto de vista temos que pensar

\footnotetext{
${ }^{123}$ Vico, De ant., [Cf. Lm, cap. II, Origine e varità delle scienze, p. 68-70].

${ }^{124}$ Nesse pressuposto encontramos com precisão o princípio da auctoritas como parte da razão, porque dela participa, mas com ela não se identifica. Como observamos no Capítulo I dessa tese.

${ }^{125}$ Quanto a bondade de Deus, dá-se aqui a superação da dificuldade apresentada por Damiani no Capítulo I com relação ao verum factum.
} 
o conatus enquanto processo do movimento ideal em relação ao processo de extensão que se dá através do ponto metafísico ${ }^{126}$. Considerando-se o conatus como um intermédio entre a quietude divina e o movimento das coisas, o ponto seria o termo médio entre a infinitude de Deus e a divisível finitude da coisa. Ao desenvolver sua teoria do conhecimento em consonância a ordem do certum, Vico vai conceber o ponto metafísico como elemento bivalente, atribuindo por sua vez a este conceito um momento ideal e outro existencial, tendo, portanto, uma dupla função: princípio da existência enquanto fundamento da matéria na qual insere-se o conatus, e simultaneamente o ponto seria princípio da extensão e o correspondente do conatus. Desse modo teríamos: Deus, o ponto metafísico e a matéria, que se fundem no conatus para de um lado, dar à natureza o seu aspecto dinâmico, e de outro, sempre através do ponto metafísico dar à natureza o seu aspecto extensivo. Sem dúvida esta posição viquiana é resultante da concepção do certum por ele assumida enquanto co-relação necessária entre antinomias como duas faces de uma mesma moeda e, por isso não uma verdade absoluta, mas verossímil. Daí a admissão do conceito de indefinição do processo de constituição das coisas, como podemos observar no conceito de essência:

“...a essência consiste numa substância indivisível, e que outra não é, que um indefinido processo, ou um outro esforço do universo para colocar fora e sustentar toda coisa particular; tal que a essência do corpo seja um indefinido processo para mantê-lo distenso, o qual, a coisa distensa, quanto desigualíssima, vos seja igualmente subjacente, e que esta extensão, seja indefinido processo para mover, que igualmente está aos movimentos quanto se quer desiguais; o qual processo eminentemente é ato em Deus"127

\footnotetext{
${ }^{126}$ Em Nicolau de Cusa encontra-se a concepção da primeira forma herdada por Vico, que discorre acerca da compreensão da construção da geometria e da aritmética que se move do ponto e do número um, que em Vico encontra-se na sua concepção sobre o conhecimento em Deus e no homem, a partir da fórmula do verum factum.

${ }^{127}$ Vico, Opere Filosophiche, [Cf., Riposta I, p. 136-137].
} 
O ponto metafísico é único, é o elemento da extensão que subjaz igualmente nos mesmos elementos desiguais simultaneamente. Os pontos são inumeráveis enquanto realidade dinâmica daquele único processo que desvia-se na multiplicidade dos indivisíveis processos, cuja infinita eficácia emerge da realidade ideal da coisa ótima, da essência formal. O ponto viquiano não é matéria em sentido atomístico, pois é o prius da matéria, isto é, o primeiríssimo movimento, mas, também, não é energia pura, pois enquanto processo da extensão pressupõe a matéria.

Encontramos na acepção viquiana o rastro da concepção cusiana, porque o ponto é também elemento mental humano supostamente idealizado por motivos ontológicos-existenciais, já que o ponto é origem de existência da matéria e da natureza.

Em última instância o conatus aparece condicionado pela matéria que surge do ponto metafísico, sendo, por isso, o princípio do qual surge a natureza, na qual o processo extensivo do ponto a torna existente.

O conatus, nos afiança Vico, é o processo do movimento, ele é intrínseco fluir da vida de todo existente, é o fazer-se da existência. O ponto metafísico ao contrário, sendo o princípio da matéria e da extensão, apresenta-se como acepção estática do quod substat. Isto que mais comumente chama-se movimento é reduzido às variações que a recíproca ação dos existentes gera em toda singular determinação. ${ }^{128}$

Na sua mais ampla acepção, o conatus oferece interessante analogia com os motivos vitalísticos que se pode encontrar nas correntes gnóstico-místicas do seiscento ${ }^{129}$. Sobre este plano vitalístico encontramos como ponto de contato os motivos espirituais e sensíveis: a animação

\footnotetext{
128 Essa discussão acerca do movimento, Vico herda de Mattia Doria ( que pertencia ao grupo filosófico napolitano, cujo Libro Primo ossia Matafisico lhe é dedicado). No entanto, são teses desenvolvidas por Hobbes acerca do conatus, por Locke e físicos ingleses, acerca da extensão e, Leibniz, acerca do ponto metafísico, [Cf., Guido de Ruggiero, La filosofia moderna, Da Vico a Kant, Vico e L'uminismo italiano, p. 47]. Para deixar mais clara a equação, digamos assim, viquiana, temos a Essência Formal que compõese de infinitos pontos metafísicos e que através de um processo de combinação entre si, formam a extensão, isto é, dão existência aos seres, produzindo os fenômenos. Esta combinação é a geradora do existente, das coisas, mas não confunde-se com o ponto metafísico que é o elemento singular desta cadeia existencial.

129 A. Corsano, G. B. Vico, [Cf., op. Cit., p. 127-134].
} 
vitalística do real que volatiliza-se em termos de clarificação metafísica, cujo processo físicobiológico perpassa pela psiqué e através dessa torna a mente capaz.

O conceito de vitalismo em Vico define-se a partir da correlação entre natureza e espírito. Trata-se de uma doutrina acerca de todos os aspectos da vida na sua diversidade e contradição. O vitalismo em Vico delineia-se no De antiqüíssima $(\mathrm{Lm})$ por meio do princípio do conatus, considerado como fundamento comum das determinações corpóreas e espirituais. Assim os sentidos e o instinto humano reduzir-se-iam a simples forças naturais, bem como a realidade civil e histórica resultariam desse princípio que é o conatus. Não sendo manifestação de uma força sobrenatural, surge como força peculiaríssima da natureza através dos sentidos e dos estímulos corpóreos. Percebemos o alcance desse conceito que vai do plano humano ao plano da natureza manifestando uma visão do certum, ao conjugar os dois níveis: a realidade humana parece ser concebida como continuação do mundo físico, ato de criação regida pela divina providência, pois o corpo, bem como os elementos físicos, isto é, a natureza, pertencem a uma mesma realidade.

Os bestiones, enquanto homens, amparados pela providência divina foram capazes de se relacionar com a natureza e com ela conviver em toda a sua adversidade dando ordem e freando seus instintos em função desta força propulsora natural, o conatus.

Vico analisa no De ant a realidade bio-psíquica do homem a partir da anima e do animo (aquela correspondente as mais elevadas funções da psiqué humana e, essa, mais pensante, ligada aos sentidos e àquela condicionada) no sentido de compor uma síntese entre esses elementos através da descrição vitalística, envolvendo órgãos e funções do corpo na tentativa de refutar a tese cartesiana muito em voga na época acerca das funções do corpo, segundo a qual o espírito que recebe as impressões do cérebro de uma de suas menores partes, a glândula pineal.

"Noto também que o espírito não recebe imediatamente a impressão de todas as partes do corpo, mas somente do cérebro, ou talvez mesmo de uma de suas menores partes, a 
saber, aquela onde se exerce a faculdade que chamam o senso comum, a qual, todas as vezes que está disposta da mesma maneira, faz o espírito sentir a mesma coisa, embora as outras partes do corpo possam estar diversamente dispostas, como o testemunha uma infinidade de experiências, que aqui não é necessário relatar"130

Essa discussão demonstra o percurso viquiano na busca de inserir a filosofia natural no âmbito da metafísica, refletindo a concepção do certum que Vico empreende sobre essas questões, pois a mente humana não seria movida por elementos como o ar ou o éter, nem o espírito receberia impressões da glândula pineal, mas através da graça divina. E só na idéia de Deus a mente encontra o seu complemento e conhece verdadeiramente a si mesma. Diferentemente do pensamento naturalista latino, percebemos uma certa hipostasiação do pensamento viquiano.

"Os latinos pensavam que a imortalidade se deveria atribuir ao animus e não à anima. Talvez a razão desta afirmação deve-se ao fato que os seus autores observaram que são livres segundo o nosso arbítrio os movimentos do animus, embora aqueles da anima dependam do corruptível organismo do corpo; e estimaram que o animo, já que se move livremente, tende ao infinito e à imortalidade"131

De certo modo, a mente humana incide sobre a realidade sensível, já que os homens não conseguem ver senão coisas finitas, as quais, parecem ter os seus movimentos excitados pelo corpo. E assim, tais coisas parecem ser conhecidas pela mediação dos sentidos. Por isso a mente aparece como faculdade ligada à realidade bio-psíquica da existência, mas, simultaneamente, enquanto realidade movida por Deus, transcende infinitamente o plano da experiência e ergue-se ao pensamento do divino.

\footnotetext{
${ }^{130}$ Descartes, Meditações, [Cf. Meditação sexta, § 34, p. 139-140]

${ }^{131}$ Vico, De ant,[Cf. Lm, cap. V, I, Animo e anima, p. 104].
} 
"Se compreende que todas as coisas são agitadas por um movimento perene e que a natureza não é de fato imóvel, este compreenderá também que um corpo, aparentemente imóvel, não está excitado pelo movimento do impulso da mão, mas induzido por um movimento diverso. Compreenderá também que não está em nosso poder mover alguma coisa, mas que Deus é o autor de todo movimento e que ele desprende o conatus; que o conatus, pois, dá início ao movimento e que nós só podemos dar uma determinação ao movimento; que outras determinações são produtos de um outro gênero de mecanismos; que o comum mecanismo de todos os movimentos é o ar; que a circumpulsão do ar é a sensível mão de Deus pela qual se move todas as coisas, qualquer singular coisa é movimento de maneira muito diversa através de um particular mecanismo"132

\subsection{O livre arbítrio}

Esta relação com o divino em Vico, tem dupla valorização no que diz respeito ao livre arbítrio, pois a liberdade enquanto dom divino, não condiciona o homem numa inexorável lei natural, mas como sinal de superioridade humana sobre todas as manifestações da natureza, permite a ele de rebelar-se a toda ordem racional para entregar-se a uma sensibilidade e a uma passionalidade caótica, demonstrando desse modo, que a liberdade humana proviria do fundamento da rebelião e da exaltação da finitude individual frente a uma ordenação de toda a existência na contemplação a Deus, na fase pré-adâmica. Na perspectiva histórica, o arbítrio proviria da capacidade de superar a decadência e as paixões. No entanto, não poderíamos entender este valor positivo da liberdade senão como meio de superação e restrição dos estímulos sensíveis, pois a

\footnotetext{
${ }^{132}$ Vico, De ant., [Cf. Lm, cap. VI, Il moto non si comunica, p. 102]
} 
liberdade é parte integrante da auctoritas, daquele suum proprium esse, do qual nasce a sociedade, sendo por isso conservação e potencialidade da força vital.

“...o homem possui livre arbítrio, ainda que débil, para fazer das paixões virtudes; mas que é naturalmente ajudado por Deus através da divina providência e, sobrenaturalmente, pela graça divina.

O arbítrio humano, de sua natureza muito incerto, certifica-se e determina-se com o senso comum dos homens acerca das necessidades ou utilidades humanas, que são as duas fontes do direito natural das gentes" 133

Não sendo sobreposta aos sentidos, a liberdade deve ser entendida como princípio intrínseco de convergência da força ordenadora ou conatus que encontra em si mesma o meio para reintroduzir-se no caos da sensibilidade. Neste sentido a liberdade é um meio para limitar uma desordenada passionalidade, um subtrair que não combate o uso da força instintiva, apenas o seu abuso, e a esta, opõe-se, medindo e ordenando a exigência utilitarista, não através de uma extrínseca coerção, mas através de uma intrínseca conformação aos limites enquanto previdência que emerge através da experiência ante as dificuldades aversivas, gerando o instinto de preservação.

A propulsora e latente racionalidade que vive no homem como vis rationis implica na criação da razão por Deus, não tanto em vista de um pacífico domínio sobre todas as outras faculdades, mas para exercitar a sua ação ordenadora e mensurável na realidade sensível. Este limite de uma existência finita ligada indissoluvelmente às motivações sensíveis constitui a capacidade de opor-se à ilusão racionalística de por-se fora do condicionamento sensível enquanto possibilidade de entender a liberdade como princípio de uma ordem, não ascética, isolada, mas social que não renegue, mas coordene as manifestações sensíveis.

${ }^{133}$ Ibidem, [Cf., Seção Segunda, Dos Elementos, tp. IX,XI, § 137,141, p. 110-111; Ei, p. 177,178]. 


\subsection{O senso comum}

Partindo deste princípio ordenador do conviver social, Vico vai estabelecer o fundamento do senso comum peculiar a todos os homens, enquanto faculdade que propiciou o comum entendimento.

Ora, se os homens no estado edênico eram determinados pela ordem eterna através da contemplação da verdade, como seria possível um acordo entre os homens bestiones voltados todos para a sensibilidade, para as paixões particularíssimas e incertíssimas, se não através de uma homogeneidade das sensações, que, por serem individualíssimas, seriam substancialmente análogas em todos?

"O senso comum é um juízo sem reflexão alguma, comumente sentido por toda uma ordem, por todo um povo, por toda uma nação ou por todo o gênero humano"134

Nas Orazioni inaugurali Vico já se referia ao senso comum enquanto fundamento do verossímil, e na Scienza Nuova é a manifestação do verdadeiro no âmbito do certum ao conduzir seu argumento através da vis rationis imersa na sensibilidade, posto que assim, foi possível demonstrar com as provas filológicas

"a ter confirmada a sua autoridade com a razão e a confirmar a razão com a sua autoridade $e^{135,}$

No senso comum como incidência irreflexa e providencial da razão nos sentidos realiza-se a superação do individuo caracterizado pelo arbítrio de natureza incertíssima, e a

\footnotetext{
${ }^{134}$ Ibidem, [Cf. Secção Segunda, Dos Elementos, tp. XII, § 142, p. 111; Ei, p. 179].

${ }^{135}$ Ibidem, [Cf., Secçaõ IV, Do Método, § 359, p. 190; Ei, p. 248].
} 
conseqüente abertura da certeza da consciência à verdade, revelando-se como mediador entre a certeza e a verdade.

A concepção da racionalidade enquanto vis veri ou vis rationis que penetra e vivifica a realidade dos sentidos, fazendo dos sentidos humanos a abertura da individualidade ao senso comum, constitui a primeira e essencial força ordenadora da possante vitalidade sensível que propicia o surgimento do ato criativo da consciência, revelando uma substancial unidade entre a consciência sensível e a consciência abstrata; fazendo daquela não um simples sentido, mas um sentido vivificado pela força da racionalidade. Esta força como potencialidade ainda não está em ato, mas como condição de possibilidade que emerge de forma latente. Não seria um elemento estático, mas emergiria de um letárgico processo, num fluir que recebe das sensações mediante o senso-comum e transcorreria entre as diversas disposições, como a fantasia e o engenho por exemplo, numa lenta ampliação do fluxo contínuo em germinação.

No entanto temos uma importante identificação da consciência do homem primigênio com a consciência prevalentemente sensível. Esta consciência que caracteriza a vida dos homens primigênios constitui de fato a matriz daquela criatividade, da qual nasce o mundo das nações, a realidade civil da vida humana.

É próprio da consciência primordial toda sensitiva, o emergir da crtiatividade humana sobre o plano de sua realidade. Esta criatividade enquanto poeticidade da consciência sensível é sua verdadeira característica, não sendo, portanto, uma mediação lógica, mas uma indistinta emocionalidade criativa proveniente de uma tópica sensível como raiz originária da ordem linguiística, responsável pela gênese da mente primitiva comum a todos os homens: o senso comum. Esta tópica, sem dúvida, foi a base de toda a criação poética configurada nos universais fantásticos enquanto "lugares sensíveis", permitindo a identificação do sentido comum a todos os homens na percepção de uma mesma realidade, consistindo a linguagem figurada primitiva na criação de sentido da experiência vivida na germinação sonora que assumiu tons, tempos, pausas e ritmos. 


\section{5. $O$ engenho}

A faculdade que guia este senso comum, é segundo Vico, o engenho, o qual possui uma função "inventiva” e não "dedutiva” ou “abstrata”, que estabeleceria relações entre as coisas.

Tanto no De ratione quanto no De antiquissima, a preocupação de Vico contrapunhase à atitude cartesiana, nos confrontos da física e da experimentação, insistindo no engenho como a faculdade pela qual o físico deveria valer-se, e não no método analítico próprio da geometria, que debilitaria aquela argúcia do cientista na investigação dos fatos.

“O engenho é a capacidade de juntar na unidade as coisas separadas e diversas...é próprio do engenho estabelecer a medida das coisas; definir o bem, o útil, o belo e o torpe, capacidade esta negada aos brutos... a ciência humana consiste no dispor as coisas de modo que correspondam a uma bela e simétrica proporção ${ }^{136, "}$

O engenho é a habilidade de descobrir a semelhança entre as coisas para chegar a um elemento comum e alcançar a universalidade e, sob a base desse elemento comum haveria de fato uma transferência que percorreria entre coisas similares, como condição para o pensamento metafórico, pois nas proposições engenhosas prevalece a metáfora. No estagirita já encontramos esse percurso:

"a verdadeira transferência (eu metàpherein) é a faculdade de ver a semelhança (to homoion theorein)" ${ }^{, 137}$.

\footnotetext{
${ }^{136}$ Vico, De ant, [Cf. Lm, cap. VII, tp. IV, L'ingegno, p. 112],
}

${ }^{137}$ Aristóteles, Poetica, 1459 a 4. 
Este conceito de engenho porta uma tradição que encontramos em Baltasan Gracian (1601-1658), o qual define o engenho como:

“... a faculdade que exprime a relação entre as coisas"138,

Ludovico Muratori (1672-1750) define como

"a faculdade e a força ativa mediante a qual o intelecto recolhe, une e descobre a semelhança, a relação e o fundamento das coisas ",139.

A faculdade do engenho assume a importante função de fornecer argumentos que o processo abstrato não é capaz de "descobrir", pois

"primeiro se conhece, depois se julga a coisa"140"

A linguagem originária, fantástica e metafórica como "argúcia", por ser argumen, a agudeza do engenho, que não pode ser reduzida ao cálculo, constitui-se essencialmente pela analogia e pela metáfora, contrapondo-se à logística, pois enquanto une características comuns, a metáfora representa a estrutura fundamental da linguagem.

No processo da consciência emocional emerge o conhecimento que alcança a realidade propiciando o saber originário que se dá na capacidade contemplativa e mimética, pela qual a criatividade realiza-se no empenho de recolher o real, permitindo a sua manifestação em imagens, pois esta mente ligada ao corpo desenvolve-se como experiência sobre as coisas e fatos representados segundo a sua forma física. Daí a transferência de partes do corpo humano para a

\footnotetext{
${ }^{138}$ B. Gracián, [Cf. Agudeza y arte de ingenio, in B. Gracián, Obras Completas, Aguilar, Madrid 1967, p. 242].

${ }^{139}$ L.A.Muratori, [Cf. Della perfetta poesia italiana, a cura di A. Ruschioni 2voll., Marzorati, Milano 1971].

${ }^{140}$ Ibidem, [Cf. Últimos corolários acerca da lógica dos instruídos, tp. V, § 498, p. 322; Ei, p. 347].
} 
natureza, formando o que Vico classifica de universal fantástico, enquanto força de expressão da natureza, que se dá na experiência imediata, como a presença de Júpiter enquanto céu tonante.

"E porque em tal caso a natureza da mente humana leva a que ela atribua ao efeito a sua natureza..., e a sua natureza era, em tal estado, de homens todos de robustas forças de corpo que, gritando, rugindo, expressavam as suas paixões violentíssimas, fingiram ser o seu um grande corpo animado, a que, por esse aspecto, chamaram Júpiter, o primeiro deus das gentes “maiores”, que com o silvo dos raios e com o fragor dos trovões lhes quisesse dizer alguma coisa; e, assim, começaram a celebrar a curiosidade natural, que é filha da ignorância e mãe da ciência, que gera a admiração, ao produzir a abertura da mente do homem,... "141

Temos esta operação como atividade fantástica ou imaginativa ${ }^{142}$, na qual se exerce o engenho enquanto condição para a inventividade, descobrindo semelhanças e compondo-as a partir de uma transferência, cuja combinação, ou "colligere” é também "intelligere", e sua criação fantástica é poética. Assim temos o canto como primeiro sinal da linguagem dos primigênios, e, de certo, uivos, urros, assobios, foram os primeiros sinais cantados, já que eles adquiriram a estabilidade do significado entre o imediato fluxo das sensações que sucediam-se, suprimindo-se umas nas outras pela potência da fantasia.

"Do canto e do verso, diz Vico, foram propostas aquelas dignidades: que, demonstrada a origem muda dos homens, devem ser primeiro, como fazem os mudos, emitindo as vogais cantando; depois, como fazem os gagos, devem ter emitido, também cantando, a articulação

\footnotetext{
${ }^{141}$ Ibidem, [Cf. Metafísica poética, Da metafísica poética, que nos dá a origem da poesia, da idolatria, da adivinhação e dos sacrifícios, cap. I, § 377, p. 214; Ei, p., 264].

${ }^{142}$ A fantasia ou imaginação será tema de dissertação no capítulo III dessa tese.
} 
de consoantes. Desse primeiro canto dos povos constituem grandes provas os ditongos que eles nos deixaram nas línguas..."143

\subsection{O processo de significação}

O significado seria obtido somente se uma sensação não fosse cancelada pela sucessão de uma outra, pois só assim a mente seria capaz de produzir uma identidade através de um ponto de referência permanente propiciada pelas sensações através de imagens, que pode encontrar a sua consistência e, uma vez fixado, pode ser recordado ou ainda memorizado. Este processo dar-se-ia pelo poder da fantasia que outra coisa não é senão memória dilatada ou composta.

Que relação essas imagens haveriam de ter na produção do modo de conhecer desses indivíduos carentes de um raciocínio abstrato? Henri Bergson ${ }^{144}$ por exemplo, considera que o cérebro parece ser um instrumento de análise em relação ao movimento recolhido e um instrumento de seleção com relação ao movimento executado, cujo papel é apenas transmitir e repartir o movimento, levando-nos a intuir que a percepção enquanto função do sistema nervoso também seja direcionada para a ação no mundo material. A ação possui certa duração e exige um esforço da memória que se prolonga umas nas outras numa pluralidade de momentos, e aí residiria a representação que se prolongaria mediante o ato e se perderia em outra coisa. Estabelecendo um paralelo entre Vico e a ciência contemporânea acerca da retenção da memória de acordo com Henri Bergson, verificamos que na Scienza Nuova, esse fenômeno parte do senso-comum e do engenho

\footnotetext{
${ }^{143}$ Ibidem, [Cf. Corolário acerca das origens da locução poética dos episódios, da volta, do número, do canto e do verso, cap. V, § 461, p. 293; Ei, p. 326].

${ }^{144}$ Encontra-se essa idéia no cap. 1 "Da seleção das imagens para a representação. O papel do corpo"[Cf.

H.Bergson, Matéria e memória, ed. Martins Fontes, São Paulo, 1990, p.20,21,23].
} 
que, separa e recolhe aquilo que é percebido ${ }^{145}$. Desse modo, os bestiones $^{146}$ passaram a desenvolver a sua fantasia e a estabelecer relação com ela, pois as imagens proviriam dos elementos materiais, ou seja, da natureza.

Segundo Pagliari,

“...a ciência do primeiro conhecer humano, conhecer poético como se dá na interrelação sensitivo, afetivo e fantástico com o mundo externo. A língua em função poética dá a imagem da atividade cognoscitiva, que precede o conhecer racional; a projeção dos momentos ativos na fase dos primórdios consente a descoberta da origem humana. Esta é em substância, a grande descoberta de Vico" ${ }^{147}$,

A tese defendida por Vico acerca da Imaginação, compreende o psiquismo humano constituído primitivamente em imagens, e por isso os primeiros homens foram poetas, porque mediante as suas atividades interativas ${ }^{148}$ entre si e a natureza representavam e construíam as imagens das coisas.

A interrupção do fluxo seria o início do gesticular do sinal mudo, que seria realizado através da linguagem do corpo, isto é, das ações implementadas pelos bestiones em suas adversidades vividas, tal como Júpiter foi a primeira fixação da sensação em imagem advinda do tonante trovão, cujo céu vem pensado como um corpo ativo em movimento, manifestando o divino no rumor das tempestades e dos raios; o seu corpo balança e agita-se como o corpo dos gigantes. Esta primeira advertência do céu como um corpo de ordem diferente seria a primeira distinção do pensamento que propiciaria a distinção entre o céu e a terra. Júpiter não seria um nome que designa

\footnotetext{
${ }^{145}$ Discorremos sobre este assunto no cap. II desta tese, p89, $91 .$.

${ }^{146}$ Mantemos a palavra no original italiano, bestione, porque melhor traduz a idéia de homens rústicos, errantes e nefrários da idade divina.

${ }^{147}$ Pagliari, A., Giambattista Vico, Nel terzo centenário della nascita, [Cf. Giambattista Vico fra lingüística e retórica, p. 158, Edizione Scientifiche Italiane].

${ }^{148}$ Obviamente que tais atividades interativas são necessariamente primárias: o espanto, o medo, os urros, a tempestade, a noite, o dia, a lua, a selva, os animais selvagens etc..., fazem parte dessa realidade dinâmica.
} 
tudo aquilo que existe, pois permite aos primeiros homens de voltarem os olhos para o céu, bem como de descobrir que pertencem à terra, e desta distinção emerge a realidade do mundo. Neste processo, a terra e o mar foram vistos como Cibele e Netuno, as flores Flora e os frutos Pomona. Assim, toda a natureza era composta de corpos que comunicaram aos homens primigênios seus sinais naturais; Júpiter comandava por acenos e a natureza seria a sua língua, nos afiança Vico. Viviam, portanto, os primeiros homens num mundo de palavras reais, num mundo animado pela ação impetuosa da natureza, cujo pensar era corpóreo, porque emergia das sensações.

“É digno de observação que em todas as línguas a maior parte das expressões acerca das coisas inanimadas são feitas com transposições do corpo humano e das suas partes, e dos sentidos humanos e das paixões humanas. Como "cabeça”, por cimo ou princípio; "frente”, "costas", adiante e atrás; "olhos" das videiras e aqueles que se chamam "luzes" ingredientes das casas; "boca", toda a abertura; "lábio", bordo de copo ou outra coisa; "dente”, de arado, de ancinho, de serra, de pente; "barba", as raízes; "língua" de mar; "garganta" ou "embocaduras" de rios ou montes; "colo" de terra; "braço" de rio;..." 149.

A mente é imersa no corpo e não pode ser separada do corpo:

“...o homem, ao entender, abre a sua mente e compreende essas coisas mas, ao não entender, ele faz de si essas coisas e, ao transformar-se nelas, vêm a sê-lo"150

O pensamento dos primigênios era literalmente um ato de sentir; Júpiter era para eles a "verdade dos sentidos", pois a idéia humana haveria começado por meio da contemplação do céu

\footnotetext{
${ }^{149}$ Ibidem, [Cf. cap. II, Corolários acerca dos tropo, monstross e transformações poéticas, tp. I, § 405, p. $240 ;$ Ei, p., 284].

${ }^{150}$ Ibidem, [Cf., p. 241; Ei, p. 285]
} 
através dos “olhos do corpo". Assim os primeiros atos de significação começam com os atos mudos dos gestos corpóreos.

A primeira destas formas do pensamento corpóreo é um processo no qual o mundo seria corporificado pelos 'primeiros homens por meio da apreensão dos seus próprios corpos como já vimos na transferência metafórica. Desse modo eles entenderiam, ao comer a batata, que não seria uma simples semelhança com os contornos da colina, mas perceberiam a natureza como os olhos, as costas, os dentes e a língua de Júpiter. Assim perceberiam o seu mundo com a ajuda dos sentidos. Na segunda forma o mundo se moveria por meio de todos os corpos, e o significado que se daria a partir desta relação obtida pela ação e reação recíproca destes corpos resultaria em significar a coisa ao fazê-la, pois neste caso a sensação não cancelaria outra, mas a fixaria, determinando o processo de memorização. E na terceira, o pensamento surgiria, segundo Vico, do temor e do espanto, condições necessárias da relação com o divino, bem como na constituição e fundamento do mundo civil que resultaria na separação e contraposição com o mundo da natureza. Dessas condições surgiria o mito na dramatização da oposição ferrenha e implacável da luta entre as forças benignas e malignas, fruto da mente poética.

O primigênio criaria assim, a fábula sublime, por uma inconsciente criatividade, por si mesmo e em si mesmo, sendo portanto sujeito e objeto de sua criação, dando um significado a sua vivência, e este particular significado por ele fixado e expresso, seria a criação fantástica através da sua passionalidade, ao reagir no confronto com as coisas que o cercam. O mundo nasceria do significado da sua consciência sensível atribuída às coisas, e por isso, as coisas inserem-se na existência humana e tornam-se parte integrante do seu mundo.

A antropomorfização da natureza se dá na relação com o corpo humano, com o movimento realizado intra e entre - corpos e com a emoção advinda do caos das paixões como elemento conatural e necessário na formação do significado e na emergência dos nomes. O que vale dizer, de caráter eminentemente orgânico e rudimentar na formação da linguagem dos primigênios. 
Alguns autores consideram que há um estreito vínculo entre a concepção viquiana e o nominalismo ockhamista, quando não há essa herança singular. Há influências sim, e de várias concepções: platônica, aristotélica, baconiana, leibniziana, latinista, enfim uma gama considerável que não se esgota aqui. Mas, a concepção de linguagem que Vico desenvolve não é, definitivamente nominalista. A tese ockhamista é essencialmente semântica: a cognição, o signo e a referência são indissociáveis e, o conceito manteria uma relação de semelhança com as coisas que ele representa, seria uma significação natural que se daria pela intuição. Aqui, já temos dada, a estrutura subjacente à ratio humana como veículo de apreensão e formação da linguagem por meio da cognição. No entanto, em Vico, essa estrutura não é desenvolvida, e a significação é um produto natural que emerge da consciência emocional cercada pelas adversidades e contingências propulsoras do surgimento da linguagem, cuja validade justifica-se segundo o princípio do verum factum, que expõe as raízes emocionais, poéticas e míticas da linguagem, sublinhando que a consciência emocional é sempre significante na dupla acepção que este termo pode ter: tanto a emoção pode ter um valor ideal, uma verdade enquanto não é articulada, quanto pode articular-se determinando-se num processo lógico-poético, enquanto fábula que é a forma de descrição de uma realidade particular por imagem, pois os homens primigênios não possuíam a capacidade de dar ordem ou de conceber a realidade perceptível do mundo humano ou da natureza com a ajuda de uma singular propriedade que fosse abstrata, pois não tinham o conhecimento de um mundo de objetos e de indivíduos bem distintos, mas ao contrário, de um mundo de forças e de robustíssimas paixões.

Vico considera o míto a base daquela criação humana no caos das paixões, cuja articulação na sua determinação lingüística é o elemento essencial para que se realize a comunicação. A estrutura do mito implica na abertura da consciência à comunicação e põe-se como fundamento do convívio humano.

A identificação do ato criativo da consciência humana como fundamento do conviver justifica uma nova interpretação da tese convencionalista da linguagem enquanto função das 
convenções de princípio adotadas, ou seja, de que se tenha chegado a um "acordo" com referência a certas "verdades" básicas. A convenção que pode ser abstrata confronta-se com uma natural apropriação do nome ideal provindo das necessidades humanas. O significado concreto da coisa em si revela-se necessariamente real, enquanto exprime o real conviver entre os homens pela comum criatividade de suas mentes. A força da natureza seria personificada e desse mesmo modo o nome seria o translato da atividade do espírito provindo de uma visceralidade primordial reportando-se ao fato, que ocorre no momento da criação, exprimindo-se numa idéia substancialmente primária, emergida das entranhas vivenciais numa inusitada reação sensitiva. Este 'nome' não seria apenas um nome como um rótulo para identificar, mas, mais do que isto, seria a própria coisa inanimada, vivificando-se numa translação do próprio corpo vivificado, numa co-relação sem pausa, necessariamente umbilical.

E a convencionalidade da linguagem não é aqui artificiosa, mas natural e real, da qual nasce a criação do mundo civil. Na verdade não temos uma convencionalidade, temos, sim, uma espontaneidade primordial, fruto do modo de ser dos homens primigênios que pouco a pouco foi tornando-se regra, convenção, pela uniformidade que os significados foram tomando em relação as suas respectivas referências e ao uso comum. A criatividade mitológica pressupõe a coesão dos homens na realidade social, mas isto só pode ser considerado nos limites que Vico claramente distingue nas três línguas: a divina, a heróica e a humana, que não devem ser entendidas numa sucessão do tempo, mas numa co-existência, numa simultânea variedade. A língua dos deuses é quase toda muda; a dos heróis, muda e articulada e a dos homens articulada e pouquíssimo muda.

A linguagem muda própria dos bestiones, rudimentaríssima, dava-se por sinais como gesticulações, urros, assobios ou por objetos que indicavam alguma coisa, ao transferir significados referenciais que implicariam numa convencionalidade, já que o objeto não seria representado para indicar a si mesmo, mas indicaria algo próprio na inter-relação com a vida humana, daí as línguas terem começado por palavras monossilábicas. 
"Em grego e em latim, são por monossílabos, os pronomes, cujo uso deve preceder aqueles dos nomes, como todos os dias ensinamos às crianças. Na língua latina são monossilábicos, quase todos os primeiros vocábulos das coisas, e daqueles objetos que primeiramente firmavam a atenção dos homens: hoc, por "céu” [(e nos começos é comum as expressões Luciscit hoc iam por luciscit iam coelum)]. Sol, lux, nox; no homem, os, frons, cor, cus,

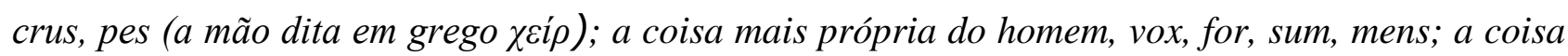
mais necessária, lux, fons, [nux], glans, $\pi \tilde{u} \rho$, nome grego do fogo (e a voz Dis, conservada pelos poetas, não haveria ela significado a terra?). As coisas mais prazeirosas, lac, mel, própria da idade de ouro; nas plantas, stirps, flos, frons, frux; os animais mais úteis, bos, sus, (e ovis em grego öıs, foi talvez originalmente monossílabo, e depois tornou-se dissílabo); a matéria pecuária, grex; a rústica, rus; res que na infãncia é um vocabulário; o primeiro frumento, far; o condimento, sal; utensílios de casa, vas; o primeiro metal aes; a primeira moeda, as; o mais rústico dos deuses, Pan, como também Stix, palavra com a qual referencia o fundamento da sociedade dos deuses; $e$ aqueles vocábulos que exprimem todos os princípios do viver civil, vis, vir, gens, Urbs, rex, dux, merx, pax (de onde pacisci, pactuar), jus, faz, mos, lex. Mas não pode ter havido a palavra lex o significado que encontramos em aquilex, o qual significa o homem esperto no encontrar e no (elicere) a água”. ${ }^{151}$

\subsubsection{A poeticidade mítica}

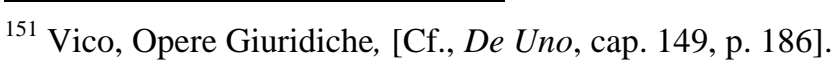


O mito é linguagem enquanto poeticidade da mente humana, pela qual subsiste no domínio dos sentidos, convertendo-se em miticidade a partir dos costumes, das leis, da religião, da disciplina, ao implicar na criação de um mundo civil, no qual a comum origem divina de todos os homens expressa-se na sociedade: o mito é experiência fundamental do espírito humano, é o momento insuprimível da linguagem enquanto pré-ordenação, ao limitar as ações dos homens e, ao estabelecer a comunicação entre eles.

A linguagem para Vico põe-se como questão universal, pois reflete toda a criatividade que o homem opera, produz e nela entranha-se, determinando-a por um ato de liberdade que deu-se nos primórdios, sobretudo pela sensibilidade e pela fantasia. A importância por ele atribuído na fase primigênia aos fatores poéticos, e a pouca relevância dada aos aspectos operativos e funcionais da comunicação que são próprios da língua, foi talvez, a de unir com tal ponto de partida a distância entre a fantasia e a razão, já que na mente poética gestava-se a vis rationis como elemento de fermentação para a língua epistolar ou discursiva.

O esforço desmedido na constituição da linguagem no pensamento viquiano é atestado pela declaração que faz do laborioso trabalho acerca daquele modo em que os homens primigênios podiam ter pensado e falado.

“...para descobrir o modo desse primeiro pensamento humano nascido no mundo da gentilidade encontramos as ásperas dificuldades que nos custaram bem vinte anos de pesquisa, $e$ [devemos] descer destas nossas naturezas humanas civilizadas àquelas completamente ferozes e imanes, as quais nos é completamente negado imaginar e apenas com grande custo nos é permitido compreender"152

${ }^{152}$ Ibidem, [Cf., Seção Quarta, Do Método, § 338, p. 180; Ei., p. 239]. 
Do ato da linguagem, e em particular daquilo que constitui o elemento dinâmico e criativo nos confrontos da pura funcionalidade que opera na comunicação, Vico traça a justa conclusão que semelhante fator dinâmico (a fantasia) é o veículo de projeção na formação da significação enquanto elemento de distinção e consequentemente de comunicação entre os primigênios. O dado lingüístico compõe-se na sua tese com outros princípios, entre os quais o sentido e a fantasia que domina a mente dos primigênios, enquanto a racionalidade dar-se-ia numa condição posterior, já que nos sentidos encontra-se latente a vis veri ou vis rationis.

Sendo os sinais lingüísticos nos primórdios uma invenção naturalmente poética, os primigênios, incapazes de criar sinais pela abstração, pois o seu conhecimento gravitava em torno dos sentidos, criavam através da fantasia, cujo processo, dado no fluxo das sensações resultante da retenção ou memorização na sua sucessibilidade, permitiu a transferência de significados às coisas, ao associar elementos corpóreos por meio da metaforização, num permanente fluir da sensação enquanto alcance da significação resultante da projeção da fantasia na coisa. No ato mesmo em que o nome particulariza a coisa como elemento do real, se daria a significação, que. uma vez retida, se apropriaria da coisa estabelecendo a correlação entre a forma de linguagem que é puramente imagem processada pela intuição e a coisa real.

O primeiro momento dos primigênios é aquele mudo (sem a palavra articulada como sistema gramatical) frente ao mundo da sua experiência, na qual eles estão imersos como parte ou prosseguimento da própria natureza, sem dela diferenciar-se, não havendo o dualismo entre a mente que conhece e o mundo que é conhecido. O particular é o evento vivenciado através dos gestos corporais que mostram ou escondem e posteriormente fixam-se como hieróglifo ao compor significações, pois 
"os mudos explicam-se através de atos e objetos que possuam relações naturais com as ideias que eles pretendem significar" ${ }^{, 153}$

A linguagem, portanto, é também órgão do engenho, o dispositivo que media a ação e, sem a qual não se daria na origem conhecimento algum, pois a linguagem, radicada no corpo, transfere para outros corpos os limites da própria sensibilidade que transcorre entre corpos e unifica as características provindas da natureza, bem como constituem-se como vias para as primeiras generalizações fantásticas que formam as categorias conceituais enquanto imagens, como se fossem seres viventes.

Percebe-se o explicitar de uma origem desenvolvida com argúcia, detalhamentos e rigor, num inédito modo de pensar o mundo através de uma metodologia que resgatou esta ausência originária e promoveu as inferências e fundamentos resultantes de uma longa pesquisa da gênese da linguagem, que considerou o caráter incerto das ações humanas como a criação metafórica, ou melhor, o ato criador da linguagem em seu gênero fantástico, a metáfora.

No entanto, os estruturalistas negam esta origem, como podemos observar em Eugenio Coseriu:

“Mas quais são as razões da criação metafórica na linguagem? Ou melhor: podem ser investigadas as razões íntimas da criação lingüística? Evidentemente, não, visto que a criação, a invenção, é inerente à linguagem por definição. Não é possível dar as razões dos movimentos caprichosos e insuspeitáveis da fantasia humana criadora". 154

Em Coseriu, há uma forte tendência estruturalista de interpretação da linguagem, ao não considerar a concepção do certum em Vico, que negou a existência do autor Homero. No

\footnotetext{
${ }^{153}$ Ibidem, [Cf., Secção segunda, Dos Elementos, LVII, § 225, p. 137; Ei, p., 201].

${ }^{154}$ Coseriu, E., O homem e sua linguagem, [Cf. A criação metafórica na linguagem, cap. III, p. 68, 1952(escrito)-1966(publicado, ed. Presença)].
} 
entanto, Coseriu apresentou uma nova interpretação, bastante pertinente num artigo posterior, publicado em 2001, "El lugar de los universais fantásticos em La filosofía de Vico"155 , cuja análise entende os universais fantásticos enquanto noção de uma filosofia da linguagem em dois tipos: as “objetivas estáticas" e as "objetivas dinâmicas", sendo aquela voltada para as fontes de identificação de um determinado tipo de pensamento e como prova acerca da índole de tal pensamento, e esta, também considerada de "simpatética", visa interpretar as afirmações de Vico, tratando de identificar o sentido não declarado das intuições que ele procura explicitar na Scienza Nuova.

“...Vico ao situar a criação lingüística numa suposta fase "primitiva” ou "originária", chega a atribuir ao significado uma forma pré-lingüística; isto, porque não adverte que, na linguagem (como na arte), o "originário" é permanente (embora, de algum modo o intui. Temos aqui essa identidade primitiva ou "originária" entre a linguagem e a arte, onde o universal é efetivamente imagem.

De todo modo,Vico, com a doutrina das fases da linguagem, se esforça por separar a linguagem da arte, assim como, partindo da linguagem, procura diferenciar as várias formas do saber intuitivo, em particular, as formas "institucionalizadas" por tradição ou como tradições. Por isso, na realidade, Vico não exalta - ou não somente exalta - a poesia (e, por conseguinte, sua filosofia não é - ou não somente é - estética): exalta a intuição em tudo aquilo que é conhecimento humano e o "senso comum" em tudo aquilo que é obra humana: não se esquece que o certum se relaciona com a vontade. E, posto que a ciência do certum é a filologia, a filosofia de Vico, enquanto meta seria, é, essencialmente, uma teoria da filologia "156.

\footnotetext{
155 retórica y poética filosófica, p. 3-22, Ed. La cittá Del sole, 2001].

${ }^{156}$ Ibidem, [Cf.Lenguaje retórica y poética filosófica, p. 21-22]. Percebemos a mudança de concepção de Coseriu frente aos estruturalistas, que consideraram. o conceito de ausência originária como negação da origem permanente, através do método analítico que não deu conta dessa investigação ao reduzir a
} 
Retomando a questão acerca do gênero fantástico, percebemos que o plano de expansão da metáfora enquanto veículo primário da comunicação, das leis, da família, da religião e das instituições, toma corpo definitivo na idade dos heróis. O mito revela com excepcional beleza e realidade as ações que os povos primigênios na idade heróica desenvolveram em função de uma cosmovisão fantástica impulsionada por robustíssimas paixões e diferenciada dos bestiones pelo desenvolvimento de uma linguagem mais articulada, e sobretudo, eminentemente poética.

Essa passagem imperceptível, mas historicamente significante entre as duas primeiras idades na sua expansão lingüística demonstra a capacidade da mente primigênia na sua plenitude poética enquanto ato indissociável do homem com a natureza, com a divindade e entre si, na constituição de instituições que permitiram a comum convivência, marcada pela autenticidade das atitudes em vista de uma sociedade caracterizada pelo comando e pelas leis própria da auctoritas, do pater familias que assume a virtude na condução do seu povo, como o herói transmigrado da figura de Hércules.

\subsubsection{A passagem da Idade dos deuses à Idade dos heróis}

\footnotetext{
metáfora a uma definição lingüística de per si, como se a linguagem fosse um ente auto-suficiente. Ora se assim fosse, o homem primigênio poderia prescindir da fantasia e falar discursivamente.

"Para os estruturalistas: a linguagem precede necessariamente o ato da fala de cada um de nós e é uma condição absolutamente necessária da sua existência e realização. Contudo a língua só existe, comoefeito-de-uma-ausência, na multiplicidade de falas que quotidianamente se cruzam..a estrutura como algo que apenas está presente nos seus efeitos e que inclui entre os seus efeitos a sua própria ausência, a estrutura como algo que põe o sujeito em cena e lhe atribui um papel, sem nunca se tornar visível na plena evidência dessa cena, a estrutura como estruturalidade - que caracteriza todo o "estruturalismo" científico". [Cf. Eduardo Prado Coelho, Introdução a um pensamento cruel: estruturas, estruturalidade e estruturalismos, tp. IV.4, p. XXVIII].

"É por isso que se torna impossível resolver o problema da origem da linguagem, porque ela só pode ter surgido de uma só vez, como uma nova ordem, a ordem humana, que súbitamente se instaura", E.P.C.
} 
Não mais nos deteremos na descrição de uma estrutura subjacente à linguagem na sua origem, pois sobre isso já discorremos. Seguiremos as vias de expansão dessa linguagem poética na formação da língua enquanto expressão dos limites que permitiram a passagem da idade dos deuses para a idade dos heróis.

“O segundo falar, que corresponde à idade dos heróis, disseram os Egípicios ter sido falado por símbolos, aos quais se devem reduzir as divisas heróicas, que devem ter sido as

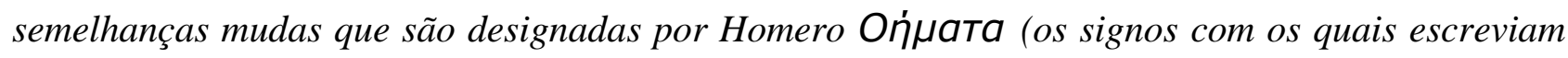
os heróis), e, por conseqüência, devem ter sido metáforas, ou imagens, ou semelhanças, ou comparações, que depois com língua articulada, fazem toda a alfaia da língua poética”,157

Os falares nasceram dessa rusticidade das mentes heróicas que não perceberam a propriedade peculiar das coisas, surgindo a locução poética por necessidade da natureza humana e indigência da fala, do mesmo modo como surgiram as fábulas enquanto universais fantásticos.

Os mitos heróicos próprios da época familiar estão estritamente relacionados a primordial consciência teológica: os heróis são considerados filhos dos deuses e dessa divina filiação são considerados superiores e conseqüentemente fundaram a própria autoridade, pois os mais fortes passam a dominar e a dirigir os mais fracos. Temos aqui, uma substancial variação de perspectiva, pois o interesse está diretamente correlacionado aos homens e indiretamente aos deuses. Os heróis passam a exercer a sua autoridade como prenúncio sucessivo dos mitos civis, pois passam a ditar e a aplicar as leis.

\footnotetext{
${ }^{157}$ Ibidem, [Corolário acerca das origens das línguas e das letras; e, dentro disto, a origem dos hieróglifos, das leis, dos nomes, das insígnias nobres, das medalhas, das moedas; e, portanto, da primeira língua e literatura do direito natural dos gentios, cap. Quarto, p. 273; Ei, p. 309].
} 
Da primordial onomatopéia passou-se às interjeições, na qual a voz é articulada pela violência das paixões e, dessas, aos pronomes, pois as interjeições esgotam as próprias paixões e os pronomes permitem comunicar as idéias aos outros.

No período heróico, os objetos não são mais considerados em si como expressões da vontade divina, mas colocam-se em relação às atividades humanas, nas quais inserem-se e que assumem significados, como observamos nos emblemas, nas divisas, nas medalhas, com os quais exprime-se a posse e se estabelece a própria autoridade e o próprio direito, bem como na tradução fonética desses novos valores humanos, surgem todas as figurações poéticas como a sinédoque, a metonímia, os tropos, derivados todos da pobreza das palavras na crescente riqueza das idéias e na dominante exigência da comunicação. Aqui já antevemos a passagem para a língua vulgar.

Com o progressivo aperfeiçoamento do aspecto fonético da linguagem e com o prolongamento do mundo ideal humano distancia-se sempre mais a sapiência poética.

Na língua dos bestiones, o mesmo urro que é imediata expressão das emoções torna-se pouco a pouco claro no decurso da história. Não é a coisa em si que vai interessar enquanto relação direta das paixões humanas, mas o valor e o significado que lhes é impresso, pois o homem deixa a linguagem real e visceralmente autêntica pela linguagem artificial e/ou convencional própria das artimanhas e do engodo. É a fase da ironia.

No entanto, o decurso da história não segue uma sucessão cronológica, mas uma sucessão simultânea, pois o tempo que a percorre é um corsi e ricorsi, pois o que ocorre é uma convergência que resulta na linguagem como atividade e como forma, assim a linguagem é sincrônica e diacrônica na sua simultaneidade, na qual o tempo decorre e reencontra-se continuamente. $\mathrm{O}$ processo histórico não segue uma linearidade, mas as várias fases ou idades se confrontam permanentemente. $^{158}$

\footnotetext{
${ }^{158}$ Hodiernamente, embora estejamos na idade dos homens, na linguagem epistolar, nos confrontamos com povos primigênios como os Pirahãs, bem como, com a barbárie ritornata das invasões bélicas e das tiranias.
} 
"Agora, para entrar no dificílimo modo das formações de todas estas três espécies tanto de línguas como de letras, há que estabelecer este princípio: que, como começaram ao mesmo tempo os deuses, os heróis e os homens (porque eram também homens aqueles que fantasiaram os deuses e acreditavam ser a sua natureza heróica mistura daquela dos deuses com aquela dos homens)..."159

Essa projeção em tempos simultâneos e diversos reflete os diversos modos do nascimento do sinal lingüístico, bem como do sinal gráfico que o reproduz. Aqui, diacronia e sincronia resultam numa unidade, ao reportar-se à universalidade da natureza humana que se faz no tempo.

Os caracteres reais da fase heróica não indicam um elemento de processo, isto é, um momento ativo do real que implica numa dada situação. No entanto, aqueles, tornam-se um dado concreto, um particular, que por sua relevância assume todos os traços comuns que qualificam outros particulares, constituindo-se em gênero, em universal fantástico, pois o caráter real seria o emblema como instrumento da linguagem heróica, como podemos verificar: Aquiles assume a conotação dos homens fortes, sendo a expressão concreta da força, enquanto outros significados definem-se como expoentes de categorias de fatos e de objetos, numa transposição do conhecimento empírico para o simbólico que representa um gênero de particulares que consente com a participação de outros gêneros de particulares, a construção de frases aderentes a outras situações de fatos, posto que todo particular torna-se no ato de comunicar um símbolo que no dado singular proporciona uma expansão para transformar-se num significado abstrato. A partir daqui, esta expansão do gênero fantástico transforma-se no surgimento do gênero inteligível, ou seja, o significado torna-se conceito, condição própria da língua vulgar.

${ }^{159}$ Ibidem, [Cf. Corolários acerca das origens das línguas..., cap. IV, § 446, p. 282; Ei., p. 317]. 
Na Idade dos deuses, a língua muda é uma representação interior, uma qualidade de recognição tópica própria da sensibilidade que culmina num ponto, exprimível por um gesto, cuja indicação materializa-se em sinal hieroglífico. Quando este sinal vocaliza-se teremos um significante fônico complexo deste conteúdo: numen é uma transposição de nuo, o sinal de fixação da vontade divina e, que significava propriamente "sujeitar-se ao numen", "ter sujeição", "temer", "venerar", isto é, seguir a vontade dos deuses e seguir seus comandos e, em Juno, se refletirá no ato de unir em matrimônio (iungo) com seus ritos conexos.

Na idade heróica o dado concreto ativa-se e torna-se representativo de todo um gênero como vimos em Aquiles. Assim, também, uma certa fonte torna-se o símbolo de todas as fontes. A assunção destes significados não dar-se-ia por si mesma, isto é, numa situação que não lhes fosse propícia, como podemos perceber por exemplo., em 'ira', aonde teremos a frase "o sangue me ferve no peito"; 'espiga', para indicar as estações próprias para a queimada, a limpeza e preparação da terra para o plantio, e depois, a colheita, pois a projeção de uma noção sobre a matéria é um sinal, um emblema. Assim o mito fornece conteúdo e significado ao emblema. Nesta fase heróica a língua exprime-se mediante símbolos naturais que retratam a coisa mesma que se quer exprimir através de comparações, gestos ou objetos.

“...a segunda falou-se por emblemas heróicos, ou seja, por semelhanças, comparações, imagens, metáforas e descrições naturais, que formam o corpo maior da língua heróica, que se comprova ter sido falada no tempo em que reinaram os heróis"160

Esta fase é extremamente criativa, como podemos observar, na forma e na relação como os heróis (que também eram sacerdotes) dirigiam-se à natureza: o céu e a terra seriam um grande corpo animado.

${ }^{160}$ Ibidem, [Cf., Ideia da Obra, Explicação da pintura preposta no frontispício que serve para a introdução da obra, § 32, p. 35; Ei., p. 112]. 
“É um trecho de ouro de Aristóteles, nos Livros Políticos, aquele onde, na divisão das repúblicas, enumera os reinos heróicos, nos quais os reis ministravam em casa as leis, fora administravam as guerras e eram chefes da religião"

...E os reis romanos eram ainda reis das coisas sagradas, designados "Regis sacrorum"; pelo que, expulsos os reis de Roma, para garantir as cerimônias divinas, elegiam um que se chamasse "rex sacrorum", que era o chefe dos feciais, ou seja, dos arautos"161

Para melhor entender os limites desta condição ideal da criação fantástica, é preciso examinar o conceito de heroicidade, sobre o qual Vico discorre na sua última Orazione de 1732, intitulada De mente heroica, onde se vê que a heroicidade da mente humana provinda de Deus é capaz de a Deus retornar, se os homens aceitam a missão que essa impõe. Essa dupla valência da heroicidade da consciência que é de Deus e, sabe-se, ser de Deus, permitiu aos homens primigênios fantasiar uma filiação divina enquanto consideravam-se verdadeiramente filhos de Deus, isto é, enquanto as suas mentes foram intimamente ligadas à mente de Deus. Vico chama de heroicidade esta filiação divina da mente que se manifesta de maneira mítica na criação da fábula, numa descendência de gerações dos deuses e dos heróis que ocorre numa transposição emocional referente ao fato, sobre o qual exprime-se uma idéia verdadeiramente visceral, concretizando-se numa figura antropomórfica. Assim a criação poética vem desenvolvida através de uma indefinida natureza humana que lhe permitia compor uniformemente aquilo que se fazia semelhante entre si, pois os homens surpreendidos por uma espantosa superstição, imaginavam, viam e agiam. Sob esse aspecto o impossível crível permanece e se desenvolve nos caracteres poéticos que são expressões da carência e limitação da mente humana, e tem por função coordenar e recolher a experiência enquanto atitude comum a todos os homens, constituindo a possibilidade da comunicação entre si.

${ }^{161}$ Ibidem, [Cf., Secção Segunda, Dos Elementos, tp. LXXXIV, § 267, 268, p. 149; Ei., p. 211]. 
Esta sapiência poética reivindica o verossímil e o senso comum, e afirma a necessidade de não negar a realidade dos sentidos e da fantasia, mas de revelar o fato e o seu significado.

Uma das intuições mais admiráveis que se tem de Vico é a distinção entre significante e significado e a conseqüente distinção entre dois tipos de etimologia: a alegórica, que é própria do falar heróico e a analógica, que é própria do falar vulgar; aquela tem por objeto o nascimento do sinal na transferência sensitiva e fantástica com a coisa e, esta, promove comparações entre significados. No mito de Aquiles, a lenda do herói é narrada enquanto alegoria por se tratar de um significante em relação ao logos ( $\lambda$ ỏyoৎ) ou fábula que é o significado da força que é própria dos heróis. Sendo o mito verdadeira narração, isto é, a declaração de uma verdade, como, também é, veriloquium ou etimologia, ou seja, um falar que tem estreita ligação com o real relativo à imagem enquanto significado, ele é a condição da língua na idade heróica; a predicabilidade da pessoa e da coisa constitui, uma vez manifesta, o universal fantástico e a figura de Aquiles enquanto predicado, seria o valor. Vico chama de alegoria, à condição do particular aderente ao real que constitui a fábula. Ao distinguir esse processo criativo que da coisa promove o gênero, daquele analógico da língua vulgar que se transforma em analogia entre isto que significa e a conotação por hábito sensitivo ou, também, cognoscitivo, ao compor um outro significado. Ele vai considerar como propriedade das línguas dos primórdios, a exaltação do gênero dos particulares assim definido.

A etimologia alegórica comporta, também, a origem do sinal em si e, a analógica a inovação no âmbito dos sinais. No entanto a passagem da fase heróica para a vulgar constitui-se por uma 'contração' que individualiza-se num sinal, o sentido, que se manifesta na fase heróica. Pois nesta fase os sinais aderentes à realidade concreta seriam compostos (Aquiles ou Ulisses, Júpiter ou Juno), pois a frase que os representaria seria um dado da experiência.

"Primeiro, que com as coisas que se meditam concordam as nossas mitologias, não forçadas e contorcidas, mas direitas, fáceis e naturais, que se verão serem histórias civis dos 
primeiros povos, os quais se comprova terem terem sido por toda a parte naturalmente poetas"

"Segundo, aí concordam as frases heróicas, que se expressam com toda a verdade dos sentimentos e toda a propriedade das expressões"

"Terceiro, ai concordam as etimologias das linguas nativas, que nos narram as histórias das coisas que essas palavras significam, começando desde a propriedade das suas origens e prosseguindo pelos naturais progressos dos seus transportes segundo a ordem das idéias, sobre a qual deve proceder a história das línguas, como antes ficou dito nas Dignidades „162

Podemos observar que a metaforização ${ }^{\mathbf{1 6 3}}$ das imagens vivas, das semelhanças evidentes, das comparações, das expressões dos efeitos pelas causas, tanto das partes quanto do todo, dos pleonasmos, das onomatopéias ou imitações das vozes aos sons, dos encurtamentos de palavras juntas, das contorções sintáticas e dos episódios, foram modos de se fazer entender ao desenvolver a própria voz, pois o falar contorcido é natural efeito de quem ainda não tem a razão desenvolvida como se pode observar nos irados e acintosos proferimentos feitos nos casos retos e oblíquos que qualificavam os verbos, bem como a singular palavra desta linguagem que recaía nas abundâncias de ditongos, traços do cantar, de onde surge o falar.

Quanto ao encurtamento, temos mater mammula, que é o alimento, do qual derivam dos poetas: silvicultrix, arcitenens, nemorivagus; quanto ao pleonasmo: "Mestas lamentam, saem fora e o cercam...", "O alto Satúrnio fulgurante brilha"; a onomatopéia: "E ele o seu arco destojou brunido", "Os copados broquéis do embate rugem"; aos ditongos: "Cútis, sai do bulício pela dextra"; e também as contorções sintáticas: "A lança aqui desfere, que no instante ao Priâmeo entra aguda o reforçado fúlgido escudo, rasga-lhe a excelente Loriga e malha, a túnica penetra no

\footnotetext{
${ }^{162}$ Ibidem, [Cf. Do Método, Seção Quarta, § 353-354, p. 189; Ei., p. 247].

${ }^{163}$ Destaque em negrito.
} 


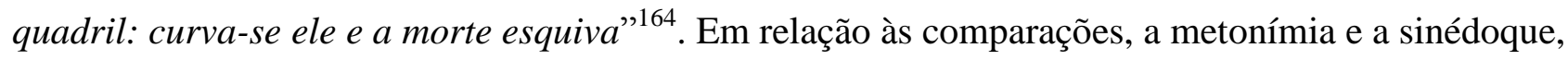
já comentamos anteriormente.

A concepção poética dos heróis nascida da fantasia e de sua humana necessidade e utilidade, criou os ícones voltados para sua satisfação e, o que atendesse às suas necessidades, bem como lhes garantisse proteção e segurança, como o falar de Júpiter foi o falar por acenos dos raios, o provedor das primeiras leis familiares, que permitiu o comando, a disciplina e fundamentalmente a agregação; Juno, símbolo das núpcias; Diana, a castidade dos nubentes que encerrou as perversões nefárias; Apolo, a luz civil que permitiu a administração das cidades e a aplicação das leis; Saturno e Vesta, o fogo aplicado à selva na preparação da terra para o cultivo; Marte, o combatente heróico que preparava para a guerra e a conquista; Venus, a beleza civil, a qual nasceu junto com uma Venus plebéia atribuída a uma pomba, não para significar profundo amor, mas porque "degenerado" o amor, seria o pássaro vil com peito de águia; um dúplice significado, patrício e plebeu foi dado a Vulcano e a Marte configurando a segregação social. Na décima segunda divindade maior começaram a refletir as tempestuosas relações dos pais de família com os fâmulos, cuja luta e sofrimento fez-se por alusão aos mitos de Tântalo, Issioni e Sísifo, sendo Hércules o caráter dos nobres da cidade heróica, assim como foi Anteo, deus dos fâmulos amotinados. Percebe-se que além de uma simbologia voltada para a virtude e caráter dos homens, tem-se aquelas que configuram determinadas situações. O nascimento da décima dinvindade, Minerva, expressa o aumento ou diminuição do poder heróico, porque Vulcano plebeu com um machado fende a cabeça de Júpiter, configurando o embate e a dissensão entre nobres e plebeus, definindo a superação de um sistema monárquico por um sistema aristocrático, promovendo a emancipação dos subjugados na escala social. Mercúrio representa a comunicação do domínio bonitário aos plebeus e a manutenção dos quiritários aos pais de família, a garantia dos direitos é

\footnotetext{
${ }^{164}$ Homero, Ilíada, tradução de Odorico Mendes, W.M. Jackson inc., [Cf. Livro XVIII, p. 322;Livro IV, p. 61,69].
} 
$\operatorname{assegurada}^{165}$. A última das doze divindades, Netuno, surge no tempo da descida das gentes ao mar, a conquista de terras e fortunas e, a fábula de Minos, da guerra troiana, do retorno de Ulisses, da Europa e do touro, do Minotauro, de Perseo, de Teseo, recordam as colônias e as corridas; Ulisses caracteriza os homens prudentes que por virtude sabem lidar com as situações e promover a justiça.

Desse modo, Vico desenvolve e revela a simbologia da concepção mítico-heróica, tendo-as como forma de pensar e dirigir a sociedade das primeiras gentes. Essa perspectiva pressupõe sempre um diálogo e um confronto do homem na sociedade através de um processo de personificação da natureza e dos sentimentos humanos, bem como o número determinado de deuses imaginados, a sua híbrida natureza e a escassa economicidade das palavras metafóricas conservaram-se por conta da pobreza da fala, porque não eram de fato sintomas de uma absurda dessemelhança, mas expressões da progressiva complexidade da vida manifestada através do politeísmo e através da polissemia, pela incapacidade de unificar fonemas similares sob a espécie de gêneros comuns, pois a mente poética estrutura a experiência formulando a identidade imediata entre os elementos, já que os particulares são concebidos diretamente como universais demonstrando a estreita ligação entre alegoria e fábula.

"Portanto, as mitologias devem ter sido os falares próprios das fábulas (pois tal significa essa palavra); de modo que, sendo as fábulas, como acima se demonstrou, gêneros fantásticos, as mitologias devem ter sido as suas próprias alegorias. Nome esse que, como nas Dignidades se observou, nos vem definido como "diversiloquium”, enquanto, com identidade não de proporção mas, para o dizer em termos escolásticos, de predicabilidade, esses significam as diversas espécies, ou os diversos indivíduos compreendidos sob esses gêneros; tanto que devem possuir um significado unívoco, compreendendo uma razão comum às suas espécies ou indivíduos (como de Aquiles, uma idéia de valor comum a todos os fortes; como de Ulisses, uma idéia de

${ }^{165}$ Vico, De Uno, [Cf. La legge agraria prima legge politica, cap. 127, p. 148]. 
prudência comum a todos os sábios); de modo que essas referidas alegorias devem ser as etimologias dos falares poéticos, que nos dariam as suas origens totalmente unívocas, como aquelas dos falares vulgares o são muito frequentemente análogas. E chega-nos também a definição dessa palavra 'etimologia”, que significa o mesmo que "veriloquium”, tal como essa fábula nos foi definida, "vera narratio",,166.

Notamos que entre a linguagem heróica e a divinatória há uma ligação visceral, posto que ambas procedem das mesmas condições corpóreas como a robusta fantasia, a metaforização dos elementos naturais, a sonorização dos fenômenos, enfim, uma criatividade toda sensitiva, própria de uma fase pré-lógica. Mas, o que realmente os diferenciava? A predicabilidade, como nos diz Vico, pois a partir daí os significados fantásticos passaram dar à composição uma maior extensão, transpondo o particular em referência aos objetos para situações instituídas como a guerra, a paz, o matrimônio, a família, a cidade, as leis e a conduta, entre outros, como observamos acima quanto à polissemia gerada pelos deuses.

A mente poética pode fazer asserções que não possuem sentido para a mente abstrata, pois assere significativamente, ou diríamos, visceralmente. Todos os membros da classe dos sábios são Ullisses; não que todo indivíduo seja um Ulisses ou como um Ulisses, mas possui as qualidades de um Ulisses. A linguagem do universal fantástico, portanto não se relaciona entre particular e universal dialeticamente, pois é narração, uma verdadeira linguagem da humanidade, na qual a vida efetiva não é aquela da categoria.

Vico, por isso, vai considerar a língua e a poesia como produções espontâneas e necessárias dos homens primigênios, não provindas do exterior por razões de utilidade e de conveniência, mas procedentes de forças primárias, pré-lógicas, sensitivas, ou seja, criação, numa arrojada composição de elementos propiciados pela própria limitação da mente humana segundo a

\footnotetext{
${ }^{166}$ Ibidem, [Cf., Secção Segunda - Lógica Poética, cap. I, Da lógica poética, § 403, p. 238; Ei, p. 282, 283].
} 
fórmula do verum factum que os dispôs à imagem e semelhança de Deus, fazendo-os agir sobre o meio para conhecê-lo, impulsionados pelo conatus enquanto força vivificante na multiplicidade de pontos metafísicos em vista de um fim positivo, que mediante o livre arbítrio deu-lhes às condições de escolha e decisão na formação das gentes, conferido pelo engenho enquanto ato de recolher e, conjugados pela imaginação enquanto ato de reunir na formação das imagens promovendo o conhecimento. Tanto esta quanto aquele, veiculados pelo senso comum sem reflexão alguma, comum a todo o gênero humano, filtrado pela visão na formação das imagens; audição, na formação dos sons; tato, na formação das espessuras e volumes e, olfato, na formação dos odores e sabores, tal como a obra da natureza que não é artificial como são as obras da reflexão. A personificação das coisas, portanto, realizada pela mente primigênia resulta na transposição de suas imagens e dos seus sentimentos por meio da metáfora, a metonímia e a sinédoque, que não é transposição intencional de um gênero a outro, mas expressão imediata de uma anima que ignora todas as distinções de um gênero e, por isso mesmo, todos os meios reflexivos peculiares à língua volgare ou epistolar, própria da sapienza riposta. ${ }^{167}$

\footnotetext{
${ }^{167}$ Contra o hermetismo do conhecimento se dirigia a crítica viquiana da sapienza riposta peculiar a bòria dos doutos que dizia referindo-se aos fundadores das Nações Gentias, os sábios de sapienza riposta, e Vico afirma serem falsas e absurdas tais opiniões. Assim, segundo Eugenio Garin temos uma dupla descoberta viquiana:"1) que a ciência não é memória, ou seja reconquista de uma originária sapienza riposta; 2) que o modo de pensar dos primigênios- de humanidade infante - não se reduz aos esquemas da racionalidade pós-cartesiana". [Cf. A propósito di Vico e Hobbes, Schede e Spunti, p. 106].

Paolo Rossi nos diz:" A origem da história humana não seria ainda, como haviam sustentado entre outros, platônicos do Renascimento, Bacon e mesmo Vico no De ant., uma misteriosa, riposta e sublime sapienza filosófica, mas provinda da grande rusticidade e da estupefata barbárie dos primigênios "bestiones" incapazes de refletir e dotados de fortes sentidos e de robustíssimas fantasias. [Cf. Critica: Giambattista Vico, Vico e Il suo tempo, p.2, Aggiornamento 2002 - Luigi de Bellis; spazioinwind.libero.it/letteraturait/antologia/vico02.htm].
} 


\section{CAPÍTULO III}

\section{A FACULDADE DA IMAGINAÇÃO}

\subsection{A formação da mente poética}

A imaginação enquanto faculdade cognoscente, propiciou aos homens primigênios a geração da linguagem como fator de comunicação entre si e a nomeação das coisas, proporcionando as condições para à formação da mente poética e colocando-se como eixo principal na aquisição do conhecimento originário.

O mito, sendo universal fantástico, realiza-se pela imaginação, que por muitos foi considerado mera fantasia, sem atinar para a função representacional que lhe é intrínseca. A imaginação é condição de coligação com a realidade na transferência de significados numa realimentação semiótica contínua. Jamais poderia ser relegada como algo irrelevante para a história e para o conhecimento, tal qual fizeram os cartesianos, mas cultivada e realçada como elemento ou eixo cognoscente, no entendimento de Vico. Possibilitou a criação da mente poética entre os povos primigênios que foram poetas e falavam mediante metáforas, metonímias e sinédoques, mediando a relação com a natureza e com os outros homens a partir de uma analogia com o corpo.

A mente primigênia apreende os fenômenos naturais como expressão de forças sobrenaturais porque projeta espontaneamente sobre estes fenômenos sua própria natureza animada, imaginando sob a forma de deuses e heróis, os fenômenos naturais e as relações sociais estabelecidas e conservadas das primeiras instituições. 
A imaginação e a corporeidade formam elos necessários na emissão dos primeiros sons, na articulação das primeiras palavras, na criação das primeiras frases eminentemente poéticas, porque a imaginação é naturalmente sensitiva, sem sê-la exclusivamente, pois nela traspassa latente a vis veri ou vis ratione que oxigena e coordena in germen as relações de configuração, conjugando transosmoticamente o sensível e o real, como já vimos no capítulo segundo desta tese.

Que relação estabeleceu Vico entre Imaginação, corpo e natureza na geração da linguagem dos povos primigênios? E como esta relação propiciou a formação dos primeiros tropos e dos primeiros topoi enquanto condição de humanização dos bestiones e heróis? De que modo a Imaginação reúne as partes que o engenho recolhe do real formando mosaicos de imagens? Que importância teve a Imaginação na formação destes povos?

Considerando este arco trinitário: imaginação, corpo e natureza, buscaremos demonstrar a decisiva importância da faculdade imaginativa na geração da linguagem, bem como no resgate de um pensar mítico que se vincula de forma irremediável a esses elementos, contrapondo-se sempre à forma de pensar cartesiana.

Os valores do intelecto em Vico se manifestam e se explicam pelo conhecimento que se dá através das imagens produzidas pela fantasia, como veremos em seguida, determinando uma ininterrupta continuidade das duas fases (divina e heróica) da mentalidade humana, tratando-se de uma mesma faculdade que exprime-se de modos diferentes, mas segundo um plano rigorosamente unitário.

A fantasia permeia toda a atividade do homem primigênio: direito, moral, religião, ciência, política, geografia, economia, física e astronomia. Tudo reveste-se na vida humana de uma áura fantástica. Homero, a Lei das XII tábuas, os caracteres heróicos, os atos solenes e formais da jurisprudência, os governos aristocráticos e as religiões politeístas, são para Vico estabelecidos sobre um mesmo plano como aspectos múltiplos de uma mesma identidade, a mentalidade poética. 
Infelizmente encontramos em Croce alguns senões acerca desta questão que indevidamente classificou a sabedoria poética de estética ${ }^{168}$, revelando, sobremaneira, a visão desfocada da concepção viquiana num desvio provavelmente kantiano. Ele considera, pois, que a natureza híbrida dos universais fantásticos:

"que seria qualquer coisa de meio entre a intuição que é individual e o conceito que universaliza"169,

se apropriaria mais do caráter mítico que da poesia e, mais,

“Aquele caráter poético, aquele universal fantástico, que introduz na estética como princípio explicativo da poesia dá lugar a tantas insuperáveis dificuldades, e por isso a definição de mito...As contradições dos universais fantásticos estão perfeitamente postas na doutrina do mito; o qual é por isso contraditório: um conceito que quer ser imagem e uma imagem que quer ser conceito, e por isso uma inópia, antes uma impotência potente, um contraste e uma transição espiritual, aonde o negro não está e o branco morre"170

Mais uma vez, percebemos que Croce não conseguiu apreender a concepção do certum em Vico, posto que sua visão reveste-se de uma pretensa exatidão ingênua; mesmo que consiga ver esta verossimilhança, ao falar da natureza híbrida e comentar ao estilo viquiano, “aonde o negro não está e o branco morre ${ }^{171 " ~ " ~ n a ̃ o ~ c o n s e g u i u ~ a p r e e n d e ̂-l a . ~}$

\footnotetext{
${ }^{168}$ A forma itálica é do autor da tese.

${ }^{169}$ Croce, [Cf., La filosofia di G. B. Vico, cap. V, La forma semifantastica del conoscere, (Il mito e laregione), p.. 66].

${ }^{170}$ Ibidem, p. 67

${ }^{171}$ Croce, [Cf. La filosofia di Giambattista Vico, cap. V, La forma semifantastica Del cono scere, (Il mito e La religione), p. 67].
} 
Primeiro, em Vico não se tem uma estética no sentido de conhecimento acerca do belo com seus vários matizes: juízo estético, estética axiológica, estética semiótica, formalista, intuicionista, psicológica e sociológica. Temos sim, uma lógica poética enquanto fundamento e justificação de uma mentalidade primigênia que irrompe como meio de conhecimento sobre o mundo, e que, portanto, não se traduz em conceitos acerca do belo, posto que é necessariamente uma cosmovisão que permitiu aos primeiros homens de agirem e conhecerem o mundo. E este conhecer não é racional, é antes de tudo um conhecer sensível que se transosmotiza ${ }^{172}$ e se transfigura por necessidade e utilidade da ação humana nos seus primórdios.

\subsection{A concepção racionalista e a imaginação}

O discurso filosófico, tradicionalmente desde Sócrates, é definido como filosofia do conceito, circunscrevendo assim, a separação equivocada entre mito e razão, o que até hoje nas escolas é ensinado através de uma classificação manualesca que divide o pensamento em doxa e episteme, o primeiro considerado "reino da opinião" e o segundo, "reino do conhecimento", sendo este superior àquele, uma vez que este é o mundo da luz, e àquele das sombras. O primeiro refere-se à concepção mítica e o segundo à concepção racionalista. ${ }^{173}$

\footnotetext{
${ }^{172} \mathrm{O}$ conceito biológico de osmose define a passagem do líquido através de uma membrana, isto é, membrana e líquido se copenetram formando uma função a partir de dois entes. Do mesmo modo a transosmotização da mentalidade primigênia se deu na visceralidade da relação do homem com a natureza, em que o corpo, a sensibilidade, estendia-se às coisas numa indistinta relação humano-sígnica, digamos assim.

${ }^{173}$ Encontramos este esquema "No pequeno Manual de Filosofia", de M. Vilhena, Ed. Sá da Costa, Lisboa, 1974.
} 
Na concepção racionalista, a imaginação por tradição filosófica, está submetida ao conceito $^{174}$; ora sendo vista como elemento da mente suscetível de investigação por parte da gnosiologia, ora sendo vista como componente da teoria da arte e da estética.

A gnosiologia da imaginação é interpretada como elemento de uma atividade mental que está entre a percepção e o conceito, cujo produto é resultado da imagem introduzida na sensação para gerar uma forma suficiente que permita uma fixação conceitual do objeto, conferindo à sensação a sua forma imediata.

Enquanto parte da criação artística, a imaginação, é vista como qualquer coisa distinta daquilo concernente à teoria do conhecimento propriamente dito, pois ela possuiria uma margem de liberdade que a separa do conceito, proporcionando especiais e diversas funções enquanto baseada sobre o prazer ou sobre a tendência humana de estabelecer valores.

$\mathrm{Na}$ maior parte dos casos a imagem e a metáfora são vistas como elementos entendidos para ilustrar significados filosóficos destinados a serem usados somente quando o raciocínio conceitual não consiga atingir a visão do todo, ou como mero elemento de comunicação para dar vivacidade ao pensamento. Ora, é interessante notar que a metáfora serve como elemento de sustentação do raciocínio conceitual quando este é incapaz de compor o seu próprio discurso, quando tenta asserir ou adjudicar, ou ainda, descrever ou definir uma determinada proposição metafísica mesmo referente à epistemologia no que concerne à totalidade.

Vamos verificar de que modo a metáfora se impõe enquanto condição imprescindível, pela qual o discurso científico submete-se.

No Tractaus Logico Philosophicus (TLP) Wittgenstein considerou que "a verdade dos pensamentos aqui comunicados parece-me intocável e definitiva"175,

${ }^{174}$ O Mito da Caverna no livro VII da República de Platão é ilustrativo: os homens acorrentados na escuridão, eram capazes de ver apenas sombras; os grilhões seria a concepção mítica, havia necessidade de liberta-los para à luz, a fim de que pudessem contemplar a realidade.[Cf., A República, Livro Vii, tp. $514^{\mathrm{a}}-516 \mathrm{~b}$, p. $\left.317-319\right]$. 
Vamos encontrar esta situação quando trata das chamadas proposições (pp) que mostram, isto é, aquelas proposições destituídas de sentido, sobre as quais não incide o valor de verdade e que definem ou esclarecem a estrutura e o funcionamento lógico das proposições demonstrativas, aquelas que descrevem a realidade, providas de sentido e sobre as quais incide o valor de verdade.

Analisemos especificamente a título de ilustração, a Forma Geral da Proposição $(F G P)$ segundo Wittgenstein:

"O que se espelha na linguagem, esta não pode representar"176, bem como "A forma proposicional geral é a essência da proposição"177

Ele, conclui a partir de uma notação lógica ou equação lógica, esta forma, destituindo, assim, e somente assim pode ser feito, a metaforização como podemos observar:

$$
[p, \xi, N(\xi)]^{178}
$$

$\mathrm{Na}$ escrita matemática, a quantificação é descrita por um signo, bem como as relações de ligação desta quantificação através do sinal de operação que pode ser de negação e/ou de multiplicidade como neste caso especificamente; digamos que o contínuo matemático que provém de uma leitura explícita de suas ligações, opera à maneira das valências quimicas percorrendo uma área sígnica formando cadeias simétricas de onde surgem novas formas de significação.

\footnotetext{
${ }^{175}$ Wittgenstein, TLP, [Cf.,Prefácio, Viena, 1918, p. 133 ]

${ }^{176}$ Ibidem, TLP, [Cf., pp. 4.121, p. 179]

${ }^{177}$ Ibidem, TLP, [Cf., pp. 5.471, p. 225].

${ }^{178}$ Ibidem, TLP, [Cf., pp. 6, p. 247]. Sendo p, as proposições elementares; $\xi$, as proposições complexas; $\mathrm{N}$, a negação proposicional e o traço (--), a incidência do valor de verdade; talvez pudéssemos contemplar esta equação lógica como metáfora algorítmica, mas isto é uma outra questão.
} 


\section{Para Wittgenstein,}

"o processo de calcular proporciona justamente essa intuição",179;

“A lógica não é uma teoria, mas uma imagem especular do mundo. A lógica é transcendental ${ }^{, 180}$.

Ora, Wittgenstein infere o todo, a partir do particular como observamos na $F G P$; Descartes, também infere o todo a partir do particular como ocorre com o cogito por antonomásia, que, segundo $\operatorname{Voss}^{181}$ provém de individuum pro specie, isto é, o uso de um nome próprio para exprimir uma idéia geral ou um termo comum, que também está presente no pensamento viquiano, pois a visão retórica da antonomásia para Vico é o princípio fundamental da mentalidade mítica que se expressa nas metamorfoses e ideações dos monstros.

Primeiro, observamos em Wittgenstein a recorrência a uma série de termos metafóricos: 'proposições que mostram'; 'o que se espelha'; 'imagem especular do mundo'. Verificamos que a palavra 'mostrar' provém do latim mostrare que significa 'expor à vista'. Temos aqui uma transposição de um elemento dos sentidos para um juízo; do mesmo modo 'espelho' significa 'vista', 'olho', 'transparente' e, no entanto, Wittgenstein pretendeu suprimir a metafísica.

Com estas observações queremos dizer que o discurso lógico-científico com todas as suas possíveis objetivações não prescinde da figura metafórica como veículo necessário de informação e apreensão.

Esta condição da linguagem confirma os universais fantásticos como elementos necessários de criação dos povos primigênios mediante a fantasia, cujo elemento sublime de maior relevância foi a metáfora que transfere significados e, diga-se, significados que possuem forte ressonância corporificante.

\footnotetext{
${ }^{179}$ Ibidem, TLP, [Cf., pp. 6.2331, p. 265] aqui, a palavra calcular está em itálico conferido pelo autor.

${ }^{180}$ Ibidem, TLP,[Cf., pp. 6.13. p. 261].

${ }^{181}$ Voss, Vico, La scienza della fantasia, [Cf. Gli universali fantastici, p. 79].
} 
Vejamos por ex., no De antiquissima, acerca da qualidade e da etimologia do olfato:

“Os antigos disseram 'olfato' para o odor, quase odorando, fizeram esses os odores, $e$ que depois com rigorosas observações encontraram verdadeiros e naturais filósofos, que os sentidos faziam a qualidade que são ditas 'sensíveis'. E finalmente disseram 'saber' o gostar, $e$ 'saber' propriamente é das coisas que dão sabor, porque provar nas coisas o sabor próprio das coisas; onde pois com bela metáfora foi dito 'sapiencia', que faz uso das coisas, as quais tem na natureza, não naqueles que fingem opiniões ",182

\subsubsection{Linguagem e imagem: dedução e indução}

Podemos dizer também que a origem da linguagem é a imagem fantástica que se universaliza mediante as trocas efetuadas entre os homens, tal que as imagens não são mais em sentido único, mas se descobrem como recíprocas; que estas mesmas imagens servem para representar também as nossas trocas com as coisas com base naquela identidade da ciência e teologia naturais que implica na dinamização do misterioso mundo da natureza, fruto do fazer divino. A possibilidade da passagem destas imagens memorizadas de sentido único àquela recíproca, e depois a sua utilização em função da disponibilidade natural é dada pelo senso comum por meio do corpo e/ou imaginação. Do mesmo modo a teologia natural é corporificada, ou seja, utiliza elementos primários como o fogo, a terra, o ar e a água através da semelhança dos membros humanos, como apoio à essência das representações fantásticas dominadas pela dependência sensível do nosso engenho. Neste sentido, em Vico, há uma equivalência entre saber natural e

\footnotetext{
${ }^{182}$ Excerto citado por Nicola Badaloni [Cf. Giambattista Vico nel terzo centenario della nascita, $L a$ Scienza Vichiana e L’illuminismo, p. 114]
} 
revelado que expressam na factualidade imediata o seu sentido e a sua lei, tal qual afirmamos no Capítulo Primeiro desta tese acerca do verum factum.

Consideremos agora a questão relativa à intuição, já que o discurso abstrato-reflexivo de caráter dedutivo que se dá mediante categorias não admite que se possa chegar ao universal através da intuição, posto que somente através da dedução pode-se inferir ou deduzir o universal.

O raciocínio dedutivo necessita de um esquema rigidamente lógico dos termos de uma proposição para chegar a uma dada inferência que seria verdadeira, caso resulte numa verdade, isto é, sem contradição entre os termos e/ou com aquilo, a que se refere. Percebe-se que o resultado de um cálculo lógico entre termos de uma proposição teria a legitimidade de definir o que é verdadeiro sobre aquilo que é real; enquanto o real por natureza é múltiplo, variado, diverso e adverso. Ora, a aplicação de um esquema lógico-proposicional sobre a realidade resulta consequentemente num falseamento do real. E mais, não seria uma forma de ficção a aplicação de uma mensurabilidade que teria a pretensão de encerrar o todo? Como poderia a realidade enquadrar-se num esquema uniforme e redutor, simetricamente fechado? Alguns lógicos deducionistas consideram que a indução, por ser de base psicológica, necessariamente incorreria em erros, tal qual o erro que os doutos incorreram ao renegar a concepção mítica, porque constituia-se numa composição fantástica como se a essência humana por sua incertíssima natureza não fosse controversa e, os fenômenos naturais ocorresem numa sucessão certa. E a lógica da dedução não conteria erros porque resultaria de um processo matemático entre termos de uma proposição simetricamente articulados. Como se os elementos abstratos necessariamente fictícios fossem a reificação de uma verdade absoluta realizada pela omnisciência dos números. Assim como Wittgenstein definiu a FGP como a essência da proposição que em si encerra a capacidade de gerar tudo aquilo que existe ou que possa vir a existir no mundo lógico como um ente omnisciente e absoluto.

É curioso o fato de que a lógica formal conceba o real como a si mesma e utilize métodos abstratos, fictícios, como se neles o real portasse uma identidade entre fatos e signos. Não 
haveria nesta perspectiva uma dose suficiente de fantasia? Lembremos do que foi dito acerca do arbítrio na hipótese científica no segundo capítulo desta tese, bem como, no De antiqüíssima.

No entanto, o conceito tradicional de indução consiste na redução (inductio, periagogé) de uma multiplicidade a um fator comum ou a isto que permanece sempre "igual" no sentido da multiplicidade, enquanto que sobre a base da constância, os fenômenos múltiplos podem coligarse na sua essência através de um processo dedutivo.

Vico se opõe a este conceito com a "indução da semelhança" que por ele é definido como "intuição da semelhança" entre a necessidade humana e a realidade natural, da qual parte o senso comum que é sempre caracterizado por esta estrutura indutiva:

"Os argutos são aqueles que nas coisas mais disparatadas e diversas reconhecem qualquer fundamento comum, no qual, tudo convém; que negligenciam a singular coisa posta sob seus olhos; que trazem a oportuna razão da coisa da qual tratam por distantes condições de seu surgimento. Tudo isto é prova do engenho e vem chamado acumen. É necessário ainda que o engenho seja a faculdade aproximativa, porque é próprio de um gênio descobrir coisas novas.

Por este modo de pensar dos latinos nos é permitido conjecturar, que os antigos filósofos da Itália, usando a probabilidade na sua pesquisa, o método indutivo aos grupos de coisa similares não haviam aprendido nem o silogismo, nem a sorite ${ }^{183}$. Disto nos persuade também, o cálculo do tempo; de fato os mais antigos processos dialéticos foi a indução e a comparação entre coisas semelhantes, da qual Sócrates se valia; Aristóteles, pois usou nas suas indagações o método silogístico, embora Zenão tenha meditado mediante sorite. Mas, que empregara o silogismo, não tanto para unir coisas diversas, quanto para obter, sobretudo, uma espécie inata no gênero do sentido, ao gênero mesmo; que ao invés adota o sorite, juntando a causa com a causa, atribuindo ao todo a própria causa. Porém, o que segue um desses dois tipos de raciocínio demonstra possuir

\footnotetext{
${ }^{183}$ Sorite é um silogismo formado por uma pluralidade de premissas, [Cf., Dicionário de Filosofia,J.Ferrater Mora, Ed. Loyola, tomo IV (Q-Z), p. 240].
} 
um engenho, não tanto agudo quanto sutil; ele de fato, mais que ligar duas linhas, formando um ângulo agudo, parece que prolonga uma única linha. Embora adotando o sorite é, no que respeita ao uso do silogismo, tanto mais sutil quanto são mais rústicos os gêneros, que não as causas particulares de toda singular coisa"184.

Como na metafísica tradicional, Vico deriva a definição de realidade de um princípio primeiro: tal axioma demonstra a necessidade de reaprender criticamente a indução/intuição da semelhança em vista das necessidades sempre novas e variadas. Assim não se pode mais pretender formular respostas específicas a esta questão fundamental e com isto fixar a resposta num abstrato teorema válido, independentemente do tempo e lugar. Este é o significativo valor histórico da tese de Vico, já que a mutabilidade é a essência mesma do homem.

Contra os defensores da lógica se deveria dizer que a "indução por semelhança" coloca-se contra todo "formalismo" de natureza lógica: o ato indutivo e engenhoso resguarda invariavelmente aqueles problemas que trazem a satisfação das necessidades; o dedutivo, ao invés, é ligado a "um valor de verdade", a um "conteúdo espiritual”.

Vico descreve a linguagem originária, poética e fantástica, como "arguto", que corresponde a "agudeza do engenho", cuja linguagem não pode ser reduzida a um cálculo, já que a sua essência é constituída por analogias e metáforas em nítido contraste com os postulados da lógica, pois a metáfora possui na sua visão uma característica comum, a estrutura fundamental da linguagem, que é sempre fonte de argumentos novos por inferência. A lógica tenta superar o discurso metafórico eliminando as imagens da linguagem científica presumindo que a linguagem formalizada do cálculo deva substituir a linguagem metafórica que é considerada pela lógica como “imprópria”. Assim utiliza símbolos matemáticos que são reificados como expressão "própria”, isto

${ }^{184}$ Vico, Opere Filosofiche, [Cf. De antiquissima italorum sapientia, L'ingenio,IV, p. 124]. 
é, intransferíveis. Deste modo o procedimento logístico puramente dedutivo se desenvolve com rigidez, não sendo inventivo.

Contudo, tanto os cientistas quanto os epistemólogos e filósofos da ciência utilizam a metáfora por uma simples condição: a ciência não pode prescindir da invenção, da criação, do seu modo imaginativo de se inovar, posto que a mente humana é necessariamente, também, fantástica.

Caso não tenhamos esta diligência na leitura e interpretação de Vico, decerto as nossas inferências não serão fiéis ao seu pensamento. Em geral os autores como os já citados no primeiro capítulo (Croce,) fazem uma leitura não fidedigna da concepção do certum em Vico. Aliás, fazem uma leitura a partir da concepção do verum, portanto uma interpretação exterior ao pensamento viquiano, não conseguindo atingir o cerne da sua concepção, principalmente por não levarem em conta a formação teológica dele.

Ernesto Grassi ${ }^{185}$, no entanto, apresenta uma visão fiel, ao destacar com justa propriedade, que a Scienza Nuova coloca-se em confronto com a metafísica tradicional, e com o racionalismo cartesiano ao desenvolver um novo método para o pensamento científico que assume a forma de uma reformulação da tradição humanística, já que nem a metafísica tradicional, nem o cartesianismo constituem o fundamento para a "formação" do homem e, por conseguinte, para a compreensão de sua história. Apresentando a idéia humanista duas vias, sendo uma submissa e a outra de relação, ou seja, aquela da lógica e esta do estruturalismo ${ }^{186}$.

\footnotetext{
${ }^{185}$ Grassi, Leggere Vico [Cf. La prioritá del senso comuni e della fantasia in Vico],

${ }^{186}$ Ernesto Grassi afirma:’Toda a lógica sobre a base de considerações diversas, tem refutado a metafísica como procedimento de pensamento científico, mas tem também refutado, ideias "humanistas". A lógica tradicional distinguia entre dois métodos para fundar o conhecimento. O método dedutivo que inicia pela premissa e deriva a conclusão já presente nela. Que é indispensável que as premissas resultem universalmente válidas e necessárias, diversamente as conclusões seriam somente de caráter formal. Porém a premissa está necessariamente pressuposta na dedução, porque o procedimento consiste simplesmente em derivar qualquer coisa dela". Acerca da indução ,”...a lógica moderna insiste sobre esta idéia: O pensamento indutivo deveria ser entendido como a totalidade de todos os tipos de inferências indutivas, da qual a conclusão se estende além do conteúdo da premissa e por isso não pode ser asserido com absoluta certeza"[Cf., R. Carnap e W. Stegmüller, Indukitive Logik und Wahrscheinlichkeit, Springer, Wien 1959, p.1]. Quanto ao "estruturalismo nasce da idéia que é possível realizar uma "ciência humana", somente se se parte de exame do homem nos vários "contextos" ou "estruturas" através dos quais ele se realiza. $\mathrm{O}$ estruturalismo não quer que se estude o homem como objeto de uma abstrata antropologia (a definição que Vico dá ao homem é antropológica) e entende estabelecer uma metodologia
} 
De acordo com o ponto de vista tradicional as observações empíricas se revelam inadequadas para constituir o ponto que pertence às asserções científicas porque não podem mais desenvolverem-se além de um âmbito limitado da experiência; similarmente, as asserções hipotéticas são inadequadas porque resolvem-se em simples considerações de possibilidades. Noutras palavras, a proposição é cientificamente válida só se for deduzida rigorosamente mediante um axioma último indiscutível de uma maneira necessária e universalmente válida que é o tradicional processo do pensamento científico.

Com Descartes, entretanto, o fato de partir do cogito, a estrutura do pensamento científico não se distancia deste esquema. Também ele aspira derivar toda conclusão possível de uma primeira verdade seguindo o exemplo da matemática e da geometria.

Não é a toa a crítica que Vico faz à educação racionalista de sua época que tolhia a capacidade criativa dos jovens, pois só podemos criar mediante o senso comum, o engenho e a fantasia. $^{187}$

Vico conclui que este modo de proceder prejudica e enrijece, sobretudo o senso comum que é essencial para a ação, bem como elimina a prudência ou prevenção, porque um caso particular não pode ser derivado de uma premissa universal, e enfim, renega a fantasia ou imaginação que tem um caráter não racional. Por isso, Vico se questiona sobre a educação dos jovens:

“...de fato, a primeira coisa que se forma nos adolescentes é o senso comum, afim de que, na maturidade no tempo da ação prática, não se deixem levar por ações estranhas e inconseqüentes. O senso comum se gera do verossímil, assim como a ciência se gera do verdadeiro

da ciência humana".[Cf., Leggere Vico, La priorità Del senso comune e della fantasia in Vico, tp. 2, $O$ método da lógica, p. 129-30; tp. 3, L'antiumanismo dellostrutturalismo, p. 131].

${ }^{187}$ A filosofia de certo modo perdeu a sua vivacidade, tornou-se uma porfia entre conceitos limítrofes, engessando a sua pulsão e confinando-se num labirinto de formas. É penoso verificar que a formação filosófica de tradição francesa no Brasil, tenha jogado o pensamento viquiano no ostracismo, e nada mais viquiano que a cultura brasileira. 
e o erro do falso. Com efeito o verossímil é o intermediário entre o verdadeiro e o falso, já que, sendo mais para o verdadeiro, caso seja insipiente será falso...Se explica, por isso, que a nossa crítica torne os jovens incapazes para a eloqüência"188

Ora, o senso comum viquiano difere substancialmente daquele da tradição racionalista em que tal faculdade é considerada como o pensamento "vulgar" ou "comum" em sentido negativo, enquanto para Vico seria a base necessária para o homem intervir na natureza humanizando-a. Para isso, haveria necessidade intrínseca da própria condição primigênia de criar.

\subsubsection{A criação fantástica}

A criação permitiu ao homem primigênio recolher os elementos da natureza que se assemelhassem consigo e com outros elementos, por necessidade do engenho; de certo, sem ele, não teríamos como descrever determinadas situações ou momentos ou estados emocionais, pois a razão é insuficiente para isto. Como poderíamos descrever a intensidade da ira? Senão, "meu sangue ferve de tanta fúria”.

Mas, não basta interligar por semelhança, é necessário dar significado àquilo que é produto do engenho, isto é, vivificá-lo. Para isto ocorrer, somente a fantasia pode conceder a significação ao unificar as partes assemelhadas entre si, pois ela é o olho do engenho. Esta similitude não é uma exatidão, ela pode se dar nas mais variadas formas: seja retilínea, curva, oblíqua, transversal, contrária etc, ou seja a similitude não se dá numa relação apenas de simetria, também se dá mediante contrastes, diferenças, singularidades e multiplicidades. Assim a fantasia se

${ }^{188}$ Vico, Opere Filosofiche, [Cf. De Nostri temporis studiorum ratione III, p. 796]. 
expressa através dos sentidos por meio dos efeitos sensoriais provocados pelos fenômenos naturais e os combina, acresce e reveste pela pulsão primária, transformando-os em imagens vivificantes num extraordinário amplexo de paixões como ocorreu com os homens primigênios.

Esses três elementos estão coligados entre si (senso comum, engenho e fantasia), não sendo necessariamente entes independentes, pois não formam uma cadeia silogística como elos de uma corrente. No entanto ao despertarem no homem primigênio através dos sentidos a sua corporeidade como reação vivenciante (sem ser exclusivamente instintiva, pois a vis ratione, já está lá presente, de forma latente) permite ao homem agir e conhecer, estabelecendo a condição necessária para a comunicação e o trabalho.

Vico definiu trabalho, como a função de proporcionar ao homem satisfação, pois sua primeira ação foi adaptar a natureza para se alimentar, habitar, proteger e se unir. A figura de Hércules por exemplo, apresenta-se como a primeira imagem mítica que efetua a humanização da natureza, pois o homem trabalha a terra para o plantio e a colheita.

“...e contempla-o no maior dos seus trabalhos, que foi aquele em que matou o leão que, vomitando chamas, incendiou a selva némea, e de cuja pele ornado, Hércules foi elevado às estrelas (leão esse que aqui comprova-se ter sido a grande selva antiga da terra, à qual Hércules, que se comprova ter sido o caráter dos heróis políticos que devem ter vindo antes dos heróis das guerras, pegou fogo e transformou em cultivado)"189

A humanização provém dos trabalhos de Hércules, dos trabalhos dos primeiros heróis, dos príncipes das gentes, do pater familia, enquanto realidade acessível ao homem e previsão de boa colheita, fruto do seu esforço. O trabalho é concebido como função que confere a si mesmo um significado, não sendo, portanto, uma atividade meramente mecânica ou uma transformação

\footnotetext{
${ }^{189}$ Ibidem, [Cf. Explicação da pintura preposta no frontispício que serve para a introdução da obra, § 3, p. 5; Ei., p. 87].
} 
meramente técnica da natureza, mas uma correlação vital, pela qual o homem cria suas ferramentas e cultura, bem como cultua os deuses.

Desse modo, o senso comum, tem a função de proporcionar ao homem isto, do qual ele necessita e, certamente, o engenho e a fantasia operam primeiramente na ação que o homem primigênio realiza para o seu sustento ao fazer relação de semelhança entre aquilo que ele necessita e aquilo a que os seus sentidos conduzem através de uma dada situação específica existente na natureza, por exemplo, a disponibilidade de água . O homem realiza a transferência de significados que o conduz às ações apropriadas, como proteger de algum modo a fonte de água para o seu consumo. Isto é o significado do seu trabalho.

Grassi faz a seguinte observação:

"...se pode dizer que a unidade das ações como sistema fechado consiste numa necessidade que torna possível a transferência de significados a fatores ambientais neutros $e$ coloca em movimento a ação. A necessidade desaparece quando o significado se realiza. A fantasia é o "olho do engenho" porque cria metáforas originais através da transferência de significados $" 190$.

A natureza humanizou-se com o trabalho, a fadiga e a virtude hercúlea do homem primigênio, pois o senso comum, o engenho e a fantasia propiciaram esta condição, mas, o que é mais interessante, é o fato de que o homem primigênio criou a linguagem no ato mesmo de significar ao fazer transferências sensitivas e/ou corpóreas para a natureza combinando elementos entre si por meio de semelhanças para formar vivas imagens que ecoavam numa especular relação em vista de uma ordenação que a fantasia propiciou.

\footnotetext{
${ }^{190}$ Grassi, Leggere Vico, [Cf., La priorità Del senso comune e della fantasia in Vico, tp. 5, L'ambito di competenza Del senso comune: Il lavoro, p. 136].
} 
Obviamente, o conceito de fantasia em Vico difere radicalmente do conceito racionalista; Vico utilizou os conceitos de gêneros e universais fantásticos que os desavisados correlacionam com os conceitos de gênero e universal da metafísica [socrática] tradicional que subdivide e classifica os objetos individuais em espécie e gênero mediante um processo de abstração com a finalidade de apreender a essência, ou seja, os fatores comuns existentes nos elementos diversos com o fito de elaborar as suas definições como acima já verificamos.

Vico seguiu em outra direção e construiu a sua teoria recorrendo a uma nova forma de conceber o conhecimento, como já observamos nos capítulos precedentes, tendo como base de desenvolvimento teórico, os símbolos divinos, as fábulas e os personagens míticos.

Estas figuras poéticas e fantásticas não seguem, evidentemente, a mesma base epistêmica das normas do racionalismo, pois não são camuflagens poéticas de conceitos racionais, já que o conceito fantástico circunscreve em si uma multiplicidade de elementos através de uma imagem que exprime a essência em termos universais, por exemplo, Hércules como arquétipo do herói; a ave como essência dos auspícios; a testa como essência da alteza.

O pensamento racional, ao contrário, determina as diferenças entre os indivíduos para formar espécies e gêneros por meio de abstrações. Enquanto o conceito fantástico, concebido como imagem, cristaliza a realidade por intermédio do ato do engenho como uma visão direta do ato figurativo, tornando uma figura, referência e alegoria. As imagens da lógica poética são expressões do ato imaginativo, o qual predica uma relação entre coisas remotas, realizando a lógica da imaginação.

"Portanto, a sabedoria poética, que foi a primeira sabedoria da gentilidade, deve ter começado de uma metafísica, não refletida e abstrata como é esta agora dos instruídos, mas 
sentida e imaginada como deve ter sido a desses primeiros homens, pois que eram de nenhum raciocínio e com todos os sentidos robustos e com vigorosíssimas fantasias"191

A lógica correspondente a esta sapiência e metafísica poéticas, implica num modo fantástico de falar, pois são sempre

“metáforas apresentadas com semelhanças tomadas dos objetos para significarem trabalhos de mentes abstratas" ${ }^{\prime 192}$.

Portanto, um modo original de transferência do particular para o universal mediante representações figurativas, revelando uma imediata totalidade.

Segundo Grassi,

“Na lógica da fantasia o "exemplo" age como primeira forma de coordenação das idéias, e este exemplo no dizer de Vico "se contenta com uma só [coisa]” e separada do domínio da lógica da fantasia, assume a mesma função da indução que se desenvolve na lógica racional. Vico distingue explicitamente da indução racional "que não tem [= a coisa] necessidade de mais “de um exemplo”, que tem necessidade só de uma semelhança para convencer. Para esclarecer esta tese ele cita entre outros a fábula de Menenio Agrippa"193

Esta fábula discorre acerca do corpo social:

\footnotetext{
${ }^{191}$ Ibidem, [Cf. Metafísica Poética, cap. I, § 375, p., 212; Ei., p. 261].

192 Ibidem, [Cf., Capítulo Segundo, Corolários acerca dos tropos, monstros e transformações poéticas, tp. I, § 404, p. 239; Ei., p.283 ].

${ }_{193}$ Grassi, Leggere Vico, [Cf. La prioritá del senso comune e della fantasia in Vico, La lógica della fantasia, p. 138].
} 
"Houve um tempo que os membros do corpo humano não formavam um todo, como agora ocorre, senão que cada um tinha a sua própria opinião e sua própria linguagem. Todos eles estavam irritados com o estômago porque, diferentemente dos demais, ele não fazia nada senão desfrutar dos apetitosos alimentos que recebia; assim, pois, a boca, a mão e os dentes decidiram não lhe facilitar a comida, pensando em domá-lo por fome, porém a única coisa que conseguiram com a sua atitude foi debilitar o corpo inteiro. De tal modo pode ver-se que o estômago alimentava na mesma medida em que era ele alimentado, porque devolvia a comida que lhe chegava em forma de algo que é imprescindivel para a vida, o sangue, que as veias distribuem por todo o corpo"194

Partindo deste ponto de vista puramente factual verificamos a diferença entre a lógica poética e a racional. A palavra lógica provém do verbo "légein" que significa "escolher, selecionar" e "colocar junto", exatamente como se processa a função do engenho. Enquanto o processo abstrato com o qual se estabelecem relações, consiste no combinar ou ligar coisas e no separar as coisas não ligadas. A explicação e a prova deste caso nascem de um processo de derivação de relações sobre a base de uma dada premissa numa condição puramente abstrata. Os universais que devem representar o que é comum entre os indivíduos de uma classe, vêm reunidos num processo de abstração, no qual se processam as percepções dos objetos individuais e que é essencial para constituir os gêneros e as espécies, ou, de outro modo, nesta lógica, o coligar é um processo de derivação similar à atividade mental que consiste, também, num processo de derivação. Na lógica poética contrariamente, o ato de colocar em relação (légein) as coisas remotas entre uma e outra consiste numa ligação originária e imediata, que por sua imediaticidade pode aparecer somente na forma de uma visão instantânea ou em outras palavras, na forma de uma imagem.

Além disto, os universais fantásticos resultam da invenção que manifesta uma intensa força emocional própria de seus caracteres figurativos.

${ }^{194}$ Quiroga, [Cf., El cuerpo político: La fábula de Menenio Agripa, versão de Lívio, p. 244] 
Ora, considerar o pensamento viquiano da lógica poética limitado às formas puramente simbólicas é um grave erro, pois a essência da lógica fantástica e imaginativa de Vico não consiste na necessidade de imagens, símbolos ou analogias concebidas abstratamente, mas na necessidade constante de estabelecer relações mediante as atividades do engenho e da fantasia que formam a estrutura fundamental do senso comum, que se manifestam na ação humana, em especial no trabalho e nas utilidades enquanto humanização da natureza.

O significado que atribuímos à lógica da fantasia não deve ser entendido no sentido de um interesse puramente teorético no contexto de uma crítica contra a prevalência do racionalismo, mas deve-se notar que ela é um pré-requisito de uma linguagem comum que seja expressão do senso comum, de modo que na fase primigênia ela prevaleça sobre a linguagem racional ou como diz Vico, sobre a sapienza riposta.

Os homens primigênios não teriam criado ordem na experiência por meio da abstração simplesmente porque nada abstraiam. Daí a necessidade de criar (poiesis) imagens fantásticas resultantes da relação estabelecida a partir do corpo, já que o corpo enquanto intrínseca e exclusiva condição e necessidade que constitui o homem, foi o primeiríssimo e originário ser intransponível dessa criação, pois a realidade empírica previamente dada necessitava de uma ordem para ser conhecida, e esta ordem foi possível pela transferência dos elementos corpóreos aos elementos da natureza constituindo desse modo a própria identidade na identificação da natureza.

No entanto, a natureza é diversa, participante de um intenso componente fantástico que requer uma eficaz transferência entre o corpo e a verdade, daquilo que o corpo

"não é causa, mas ocasião pela qual na mente humana promoveu-se a idéia do verdadeiro" 195

\footnotetext{
${ }^{195}$ Vico, De uno [cap. XLVI, L'utilità è occasione, l'onestà è cagione Del diritto e dell'umana società, p.
} 60.] 
A figuração dos monstros é para Vico um instrumento que lhe permitiu pensar a mudança e a evolução das formas psicológica e social, portanto uma geração mental e lingüística de uma parte, e outra civil, apoiando-se numa reflexão sobre o corpo porque profundamente unidos no exercício da faculdade imaginativa.

\section{Segundo Riva}

“Os monstros são encarnações, a substantivação de uma lógica qualitativamente diversa que continuam a viver em nós, a regenerar-se em nós, porque não obstante o nosso incivilisamento e o nosso crescimento racional, encontram-se ligados a nossa natureza 'primitiva' transmitido pelo cordão umbilical da imaginação poética e da linguagem, numa palavra do corpo 196

Intensamente relacionada a uma idéia de ordem e equilíbrio das partes, a imaginação poética constitui a debilidade sobre o plano do raciocínio e a vulnerabilidade sobre o plano social, mas representa, também e sempre, a força criativa do engenho, só e somente humano. Não é acidental que os monstros descritos por Vico não pertençam a usual teoria teratológica ${ }^{197}$ ligada às teorias da reprodução que via nos monstros a produção de figuras duplicadas e mal formadas, mas para sempre compostas de semelhanças com as várias partes do corpo humano, do qual emergem os signos.

“Os monstros e as transformações poéticas resultaram por necessidade dessa primeira natureza humana, pois, como nós demonstramos nas Dignidades, não podiam abstrair as formas ou as propriedades dos sujeitos; pelo que, com a sua lógica, devem ter composto os sujeitos para comporem essas formas, ou destruir um sujeito para separar a sua forma primeira da forma contrária nele introduzida. Tal composição de idéias produziu os monstros

\footnotetext{
${ }^{196}$ Riva, , Vico e il mostro civile,[Cf., in "Bollettino del Centro di Studi Vichiani” XXXIII (2003), p. 122]

${ }^{197}$ Estudo das monstruosidades.
} 
poéticos: como no direito romano, ....se denominam monstros os partos nascidos de meretriz, porque tem, ao mesmo tempo, natureza de homem e propriedade de animal, por terem nascido de concúbitos vagabundos, , ou seja, incertos" $" 198$

\subsection{O princípio de identidade fantástico}

A descoberta viquiana do universal fantástico é a descoberta de um princípio de identidade coligado à noção de metáfora entendida como fundamento epistemológico, pois é a identidade que é originariamente adquirida na percepção, sendo sua forma imediata. Portanto, o conhecimento inicia primariamente com a imaginação. Mas, para conhecer há necessidade de se memorizar a fim de se reter as imagens enquanto referências. Em Vico, a memória assume uma particular composição:

"que é memória, enquanto recorda as coisas; fantasia, enquanto as altera e contrafaz; engenho, enquanto as contorna e põe em conformidade e ordem. Razões pelas quais os poetas teólogos chamaram à Memória 'mãe das musas",199

Sendo a fantasia a memória da coisa quando "altera e contra-faz", tem como função re-ordenar aquilo que está contido na mente para informar a forma geral do sujeito, no caso, a relação estabelecida com o corpo para poder conferir distintamente ao objeto a forma humana. Desse modo, a fantasia familiariza-se com o objeto, pois que este não é simplesmente apreendido

\footnotetext{
${ }^{198}$ Ibidem, [Cf., Cap. II, Corolários acerca dos tropos, monstros e transformações poéticas, tp. VI, § 410, p. 244; Ei, p. 288].

${ }_{199}$ Ibidem, [Cf. Provas filosóficas para a descoberta do verdadeiro Homero, cap. V, tp. IX, § 819, p.624 ; Ei., p. 562].
} 
em si, mas é formado como objeto humano, ou seja, a fantasia imprime sobre o objeto a forma do sujeito: Júpiter por ex., que causa temor nos primeiros homens ao ouvir o troar do trovão, cujo céu foi considerado seu corpo por transposição do corpo humano ao ouvir os ruídos que lhe são intrínsecos como as batidas do coração. Assim, os primigênios ao representarem para si mediante os seus corpos, proporcionaram a lenta transformação de suas vivências, no simbolismo humano por meio da linguagem e da cultura.

A troca qualitativa, simbólica, entre o homem e a natureza, conserva a indissociabilidade de ambos, uma indivisível relação entre o simbolizante e o simbolizado, portanto indistinta e não convencional, tornando o símbolo, o próprio ser, ou o próprio objeto que representa enquanto se presentifica, ou seja, realiza sua presença atual, denotando assim os nomes do real, uma pertença no sentido pleno da palavra, consubstancial.

Há nesta translação entre o homem e a natureza uma certa introvisão ${ }^{200}$ enquanto capacidade instintiva que permitiu ao homem de transosmotizar-se por meio de robustíssimas fantasias, transpondo-se aos fenômenos naturais, simultaneamente separados de si numa interligação inexorável. O primigênio transpõe-se no trovão e do trovão teme a sua indistinta separação, a sua identificação na diferença.

"Fizeram do peito a sala de todas as paixões, a que, com justo sentido, submeteram as duas fomentações ou princípios; isto é, o irascível no estômago, porquanto é aí que, para superar o mal que nos oprime, se nos faz sentir a bílis contida nos vasos biliares, dispersos pelo ventríloco, que, ao fortalecer-se, espremendo-o, lá a difunde: - situaram a concupiscível, sobretudo, no fígado,

\footnotetext{
${ }^{200}$ Este conceito de Introvisão assemelha-se ao conceito de Insight, muito bem desenvolvido por Peirce: "Denomino-o de Introvisão porque é preciso relaciona-la com a mesma classe geral de operações a que pertencem os Juízos Perceptivos. Esta faculdade pertence, ao mesmo tempo, a natureza geral do Instinto, assemelhando-se aos instintos dos animais, na medida em que estes ultrapassam os poderes gerais de nossa razão, e pelo fato de nos dirigir como se possuíssemos fatos situados inteiramente além do alcance de nossos sentidos. Assemelha-se também ao instinto em virtude de sua pequena susceptibilidade ao erro, pois, embora esteja mais frequentemente errado do que certo, a frequiência relativa com o que está certo é, no conjunto, a coisa mais maravilhosa de nossa constituição". [Cf., Semiótica, 3. Três Tipos de Raciocínio, tp. 4, Instinto e abdução, p. 220].
} 
que é definido como "a fábrica do sangue”, que os poetas denominaram "precórdios", onde Titã empastou as paixões dos outros animais, que fossem os mais insignes de cada espécie; $e$ esboçadamente entenderam que a concupiscência é a mãe de todas as paixões e que as paixões estarão dentro de nossos humores"201

"Atribuíam ao coração todos os conselhos, pelo que os heróis <<agitabant>>, $\langle<$ versabant $>>,<<v o l u n t a b a n t$ corde curas $>>$, porque não pensavam sobre as coisas exequíveis se não sacudidos pelas paixões, tal como aquele que eram estúpidos e insensatos. Portanto, os sábios foram denominados pelos latinos <<cordati >> e, ao contrário, <<vercordes $>>$ os simples; $e$ as resoluções foram denominadas <<sententiae>> porque, tal como sentiam assim julgavam, pelo que os juízos heróicos eram todos verdadeiros na sua forma, por mais que fossem falsos na matéria",202

A memória, a imaginação e o engenho são capacidades primárias da mente que permitiram a formação da experiência humana mediante a tópica sensível que é considerada por Vico como a primeira arte da civilização, isto é, a ciência divinatória do bem e do mal.

“...Mas a fantasia mais não é do que relevo de reminiscências, e o engenho mais não é que trabalho em torno das coisas que se recordam"203

A tópica sensível está ligada em Vico a peculiar modalidade de pensamento que liga convicção e sentido, assumindo na fantasia dos homens primigênios a forma de universais fantásticos, cuja linguagem se dá entre particulares e universais por meio da narração.

\footnotetext{
${ }^{201}$ Ibidem, [Cf., cap. Segundo, Da física poética em torno do homem, ou seja, da natureza heróica, § 701, p. 527,$528 ;$ Ei., 495,496$]$.

${ }^{202}$ Ibidem, [Cf., § 702, p. 528; Ei., p. 496].

${ }^{203}$ Ibidem,[Cf., \& 699, p. 526; Ei., p. 494
} 
A narração vertida na história ideal eterna é trágica, a-dialética e exclui a idéia de progresso; a linguagem se dá entre opostos de forma unitária, o bem e o mal revelam a face única do homem, portanto uma linguagem afetiva e efetiva, irredutível às categorias racionais.

Ora, o que subjaz a estas faculdades como o senso comum, a memória, o engenho e a fantasia para proporcionar ao homem primigênio, no caso específico, a capacidade de imaginar? Seria a manifestação da anima/animus ${ }^{204}$ enquanto princípios mediadores entre a mente e o corpo que emergem desencadeando as paixões por meio da linguagem (urros, falas, grunhidos e gestos) que em Vico identificam-se com a fantasia porque vêm necessariamente ligada à fecunda e vital poeticidade que gera a vida civil, isto é, a capacidade de ordenamento na formação da religião, do matrimônio e do sepultamento, pelos quais a vida civil contrai regras, formando o corpo social, como observamos no segundo capítulo desta tese.

$\mathrm{Na}$ poesia se exprime em termos fantásticos a criatividade de uma mente ainda insipiente, na qual vive o desencadear dos sentidos mediado pela vis veri, e na criação da poesia, mitos e fábulas se dão o testemunho disto que os primigênios acreditavam e conseqüentemente a partir disto faziam. Desse modo, Vico desenvolve uma análise dos mitos presente na narração poética para estabelecer os fatos do período obscuro da história, a fim de demonstrar através do valor histórico da poesia, a dignidade e a verdade da fantasia.

Para Vico esta poeticidade não pode surgir consilio et arte, mas necessitate naturae, posto que a vis rationis é a natural característica da humanidade, o processo que transforma os sentidos em poeticidade. É esta, a característica peculiar da mente primigênia que permitiu o desenvolvimento da vida civil na formação do pater familia, na ascensão dos fâmulos no âmbito da família, bem como nos cultos místicos, nas leis e na guerra.

$\mathrm{Na}$ medida em que os sentidos se revelam como mente sensível caracterizada pela fantasia poética, não se pode mais dizer que os homens sentem sem restrição, mas, no entanto, são

\footnotetext{
${ }^{204}$ São movimentos, voltados para o espírito e para o corpo, e tais movimentos nada mais é, que a coisa que se move a partir do conatus, que é o impulso do movimento. \{Cf. De Ant., cap. IV, tp., VI, Il moto non si comunica, p.102; cap. V, tp. I, Animo e anima; p. 104; cap. VI, tp. I, La mente, p. 108]
} 
homens enquanto restringem-se com o ânimo perturbado e comovido. A restrição da vivência primitiva não se pode, decerto, entender-se como um juízo racionalmente articulado, mas se exprime imediatamente numa vivência totalmente emotiva. Por isso, a poiesis fantástica se manifesta como transfiguração emocional da vida rudimentarmente sensual dos primigênios, tal qual descrita por Vico

“Deste modo, os primeiros homens das nações gentílicas, como crianças do nascente gênero humano..., criavam as coisas a partir das suas idéias, todavia com infinita diferença ao criar próprio de Deus: porquanto, Deus no seu puríssimo entendimento, conhece, e conhecendo-as, cria as coisas; eles por sua robusta ignorância, faziam-na em virtude de uma corpulentíssima fantasia e, porque era muito corpulenta, faziam-no com uma espantosa sublimidade, tal e tanta que perturbava excessivamente esses mesmos que fingindo as criavam, pelo que foram chamados “poetas", que em grego significa o mesmo que “criadores”. Pois são os três trabalhos que deve fazer a grande poesia, isto é, encontrar fábulas sublimes apropriadas ao entendimento popular e que perturbem excessivamente para conseguir o fim, a que ela se propôs, de ensinar o vulgo a agir virtuosamente, como eles a si mesmos o ensinaram,"205

No processo fantástico, a emoção é causa e efeito: causa da maravilhosa sublimidade que os primigênios atribuíam aos fatos narrados e, efeito desta sublimidade, pela qual, a criação da fantasia assume um significado e um valor específico, normativo e ordenador. Sem emoção não temos fantasia, mas somente na criação fantástica a emoção se fixa concretamente e encontra a sua justificação. Segundo Benedito Nunes, "a fantasia é tão real, quanto a realidade é fantástica"206.

\footnotetext{
${ }^{205}$ Ibidem, [Cf. Metafísica Poética, cap. I, § 376, p. 213; Ei., p.263 ].

${ }^{206}$ Nunes, B., O drama da linguagem - Clarice Lispector, Ed. Ática, S.P., 1995.
} 
Sabemos que os bestiones eram homens rústicos e estultos, por isso não restringiamse, a não ser diante de eventos tormentosos. Mas é verdade que no homem o medo instintivo se transforma em pudor, em mentalidade do mal e do erro.

$\mathrm{O}$ ato da poiesis fantástica para Vico é testemunho da incidência na mente humana da vis veri, da latente força racional, graças a qual as sensações vividas pelos primigênios vem transpostas numa perspectiva que implica a valorização dos singulares fatos em relação a um princípio universal, do qual a personificação sobre-humana é a metamorfose sensível: 'os deuses eram demasiadamente humanos'.

Há, no entanto, uma questão pouco analisada sobre o papel que a fantasia exerceu na obra de Vico na constituição dos mitos referentes aos bestiones; por exemplo, vimos no primeiro capítulo desta tese que ele reporta-se ao passado para resgatar aquilo que permanecia obscuro e que lhe causou um esforço hercúleo na revelação desta fase pós-diluviana. Decerto baseou-se na tradição latina, para daí compor em vivas imagens essa história dos primórdios, mas, além desses dados que a tradição legou na escrita, a sua inventividade foi o acabamento que a tópica sensível propiciou ao seu peculiar gênio. Não foi, decerto, uma ficção de entretenimento, mas uma retroprojeção baseada em elementos metodológicos, dados literários e históricos, que se condensaram numa arrojada pulsão criativa, a qual por ele ensaiada, foi por ele, também, vivida.

Tal deslocamento ao remoto passado desconhecido foi possível graças à fantasia reminiscente, que deveras o auxiliou na elaboração de sua Scienza Nuova que passou por vários estágios até alcançar seu acabamento final em 1744. Esta capacidade da memória utilizada pelo filósofo permite-nos a compreensão do modo pelo qual os universais fantásticos constituíram a estrutura da memória dos homens primigênios.

Embora Vico tenha partido da "intuição por semelhança" para desenvolver a Scienza Nuova, esta obra composta ao modo da geometria, portanto sintética e dedutiva, cujas premissas devem ser derivadas por um conjunto de conhecimentos e informações, tal qual nos procedimentos 
geométricos que partimos de algumas verdades para daí deduzirmos suas consequências imediatas e, se as premissas são verdadeiras, também, as conclusões devem ser verdadeiras.

“Assim, esta Ciência procede precisamente como a geometria, que constitui o seu próprio mundo das grandezas, enquanto sobre os seus elementos o constrói ou o contempla; mas com tanta mais realidade quanto mais a tem as ordens referentes aos assuntos dos homens, que não possuem pontos, linhas, superfícies e figuras". ${ }^{207}$

Como Vico poderia assegurar que partindo de um procedimento dedutivo poderíamos entender um mundo longínquo, obscuro e disperso a partir dos mitos fantásticos do homem primigênio e poético? Para entendermos como isso possa acontecer, precisamos ter presente que quando se diz que uma coisa é produto da fantasia, não se quer dizer que não seja susceptível de alguma explicação, mesmo que a fantasia seja uma faculdade psicológica entranhada no corpo e que se desencadeie espontaneamente segundo processos, exposto no segundo capítulo desta tese, de acordo com as várias dignidades que Vico estabeleceu nos Elementi da Scienza Nuova e na parte dedicada à Lógica Poética. Embora apreendamos esses elementos necessários para compor essas dignidades, não os conhecemos, posto que só Deus os conhece, pois para exercitarmos a capacidade de imaginar em conformidade com essas dignidades não precisamos conhecer a sua causa sui. No entanto, dela participamos, embora sejamos incapazes de viver e efetuar a mesma situação fantástica realizada pelos primigênios, já que isto é simplesmente impossível.

Ora, não é absolutamente necessário para entendermos o universal fantástico constituído por Júpiter por exemplo, fazermos uma imagem poética primigênia deste deus. O essencial é que sejamos capazes de realizarmos atos de fantasia e sabermos como somos capazes de formar uma imagem. A compreensão de uma fantasia havida no passado não exige que a

\footnotetext{
${ }^{207}$ Ibidem, [Cf., Secção Quarta, Do Método, § 349, p. 187; Ei., p.245 ].
} 
exercitemos como o fizeram os primigênios, ou seja, para entendermos como o primigênio vivia o seu mundo fantástico, não há necessidade de a vivermos do mesmo modo também, pois isto nos é impossível. Para entendermos que coisa fazia o homem primigênio, temos que ser capazes de entender como o homem primigênio pôde imaginar e crer num mundo fantástico. Sem a experiência da fantasia em nós mesmos ou sem a reflexão sobre ela efetuada de um ponto de vista posterior e racional, certamente não seríamos capazes de entender o mundo do homem primigênio como um mundo do qual se possa sensatamente dizer que foi para ele visceralmente verdadeiro, não havendo, portanto, nenhuma falsidade nesta concepção, mas um processo que desencadeou-se para chegarmos à razão.

A fantasia reminiscente contém em si, elementos que refletem aqueles tempos na estrutura memoriante da fantasia arcaica ou mítica que permitiu de forma consistente ao fundar o pensamento reflexivo sobre o imaginativo, retro-projetar um passado obscuro com tanta vivacidade, a ponto de conotar o estilo conceitual viquiano, que de certo, encerra-se no seu pensamento peculiarmente certum.

Como Novalis podemos dizer a respeito de Vico,

"Depois de muito refletir sobre o assunto, parece-me que um historiador deve também e necessariamente ser poeta, pois só os poetas podem entender esta arte que consiste em ligar os factos com habilidade"208.

Vico por sua vasta formação latinista e grega, soube compor com habilidade e redigir com maestria suas obras, dando-lhe uma estética prazerosa e simultaneamente, um eco poético singular, promovendo uma escritura solene, por sua erudição acadêmica e, cativante por sua retórica.

\footnotetext{
${ }^{208}$ Todorov, Teorias do símbolo, Contracapa, p. 10].
} 


\section{CONCLUSÃO}

Percorremos as trilhas conceituais desenvolvidas nos séculos XVII-XVIII em busca de uma melhor clareza sobre a visão de mundo que comportaria a concepção de Giambattista Vico, o seu modo de ver e apreender o conhecimento. Esse modo de ver viquiano apresenta-se como um modo sui generis, que buscou, de certo modo, conciliar visões aparentemente opostas entre si: o racionalismo e o empirismo, cuja síntese não se daria numa suposta lógica racionalista de cunho cartesiano, mas numa apreensão antropogênica da realidade material e espiritual focada no homem e, a partir dele, concebida na sua versão humanística.

No entanto, esse humanismo não foi um deslocamento teórico de uma razão escolástica que homiziou-se nos esquemas silogísticos do discurso acadêmico em voga, para um outro esquematismo de índole platônica, a ordem matemática. Mas, emergiu do seu inconformismo teórico e de suas investigações acerca do homem primigênio cujas sensações corpóreas fruíam para as imagens, numa irrupção de robustíssimas fantasias - ao criticar a lógica reducionista como a cartesiana e a galileana, para demonstrar que era possível pensar a partir de uma lógica que desse conta da dinâmica e controvertida natureza humana, como divisamos na sua concepção teológica tratada no segundo capítulo desta tese acerca do latente processo da vis veri no sensível, que fora eliminado pelo cartesianismo ao separar mente e corpo. Vico demonstra a possibilidade de unificar o diverso e múltiplo na lógica do verossímil.

Para dar conta da interpenetração entre esses dois elementos (o sensível e o racional) numa só unidade, que conjuga em si as adversidades e as contradições peculiares à natureza humana, em que a razão não excluísse aquilo supostamente falso 
ou verdadeiro, mas contivesse em si as condições de unificá-los e, assim, adequá-los ao raciocínio singularmente humano. Vico reconstitui a concepção do certum, que vai balizar todo o seu pensamento, demonstrando que não é apenas um rótulo que se sobrepõe a outro, mas um modus operandi, que com propriedade assumiu a forma e o conteúdo de uma visão de mundo, como apresentamos no decorrer desta tese.

Sabemos que Vico no De nostri Temporis Studiorum Ratione, questiona o método utilizado na educação dos jovens, isso em 1708, ao discordar do método cartesiano ou o método crítico dos modernos, em que o senso-comum é tido como suspeito para o conhecimento, posto que o conhecimento abstrato seria superior, uma vez que aquele não geraria a ciência. E o senso-comum gerado pelo verossímil seria o intermédio entre o verdadeiro e o falso Uma vez sufocado o senso comum, sufoca-se a criatividade. Temos aqui a primeira preocupação de Vico com a educação do homem que proporciona a busca de uma justificação que pudesse responder a essa problemática.

No De Antiquissima Italorum Sapientia (1710), temos uma crítica direta ao cartesianismo, ou melhor a René Descartes acerca da consciência e ciência como discorremos no capítulo primeiro da nossa tese e logo adiante sobre os Gêneros e as Idéias, ele desenvolve uma análise filológica acerca do conceito de verum e certum a partir dos antigos filósofos italianos.

Ora, Vico sempre realçou a importância da fantasia sobre a razão, por ser mais potente e mais aguda no homem, pois provém dos sentidos: "nada se opõe mais à razão que a fantasia", nos diz Vico em sua Orazioni Inaugurali VI (1707).

Percebemos que para dar conta da fantasia como faculdade capaz de promover o conhecimento humano, Vico necessitou de uma doutrina crítica como a Sabedoria Poética que fosse capaz de fornecer um instrumento que pudesse assegurar o 
conhecimento fantástico peculiar ao ser humano, em especial na sua infância, tanto histórica quanto cronológica.

Em 1720 no DeUno, encontramos a definição do verum e certum, como já vimos anteriormente, em que ele desenvolve as diversas distinções entre o verdadeiro e o falso, a dúvida e o certo, de acordo e conforme a mente com a coisa.

Em Vico, já divisamos uma evolução desses conceitos, os quais já começam a vincular-se aos fenômenos históricos como a autoridade (origem divina da autoridade natural; também a autoridade é nascida da razão; da autoridade natural nasce a autoridade jurídica) e as leis por exemplo, bem como, a conclusão que difere de Descartes quanto a composição da natureza humana.

Para Vico o homem não é formado por duas naturezas distintas e diversas, a partir de um pré-juízo como em Descartes (corpo e alma). Diversamente disto, para ele, existem duas coisas necessariamente diversas: "a substância inteligente e a substância corpórea, e o homem é a constituição de ambas". ${ }^{209}$

Parece-nos que a concepção de Vico a partir da unidade entre mente e corpo, proporciona a chave para perceber que o certum é parte do verum, e dele não se aparta, pois a mente e o corpo são partes de uma só natureza. Esta conclusão de Vico nos sugere a copenetrabilidade entre conceitos, bem como, a nova arte crítica filológica cujo método seria capaz de assegurar a unidade desse conhecimento que é da ordem do certum e, assim sendo, seu caráter é eminentemente verossímil, aquilo que não pode ser visto como ambíguo comparativamente à ordem do verum, mas, como parte da verdade porque dela se aproxima. Vejamos:

${ }^{209}$ Vico, De uno, [Cf. Proloquio Dell Opera, Assunti metafisici, I, p. 36]. 
“O certum é atributo próprio e perpétuo do direito voluntário, retendo nele , portanto, qualquer marca de verum, como resultado da definição do jus civil dado por Ulpiano e por nós adaptada àquela parte da verdade que se apossaram os legisladores, nós acrescentamos o certo, ou a autoridade que determinada lei, aonde obrigava os homens a observá-la, quando disto não sabia, bastava o espontâneo respeito, e a natural vergonha;..Por isto, também, sob todas as funções legais que todos no direito voluntário se encontram (não comportando o direito natural por ser generoso e veraz), subsiste sempre um elemento de verdade introduzido pela razão. Aonde havia o célebre dito de Ulpiano, "a lei é dura, mas ela é escrita", a qual, outra coisa não significa que "a lei é certa"(tem autoridade legal), " mas, não é de todo verdadeira”, por ser qualquer razão que não permite ser de todo conforme a verdade

Ora, sabemos que a busca de uma síntese entre o racional e o sensível foi uma prática levada a efeito entre vários pensadores medievais que tentaram uma superação entre o platonismo e o aristotelismo. No entanto, em Vico, esta peculiaridade contém em si, uma originalíssima forma de expressão, à medida que sua concepção teológica ao perceber a relação entre a vis veri ou vis rationi na ordem do sensível de forma latente, como divisamos no capítulo segundo desta tese, permitiu através dessa senda inovar seu pensamento, prevalentemente, ouso dizer, certumiano. ${ }^{211}$

Todas as questões acima elencadas nas obras viquianas, encontram seu pleno desenvolvimento teórico na Scienza Nuova (1744): seja na secção segunda Dos elementos em que ele dá corpo a teses já enunciada no De antiquissima., relativos à

\footnotetext{
${ }^{210}$ Vico, De Uno, [Cf., Cap. LXXXII,, Il vero ed Il certo delle leggi, p. 100].

${ }^{211}$ De certo que poderíamos dizer que esta denominação fosse banal, pelo fato de considerarmos todos os pensadores que regem seu raciocínio pelos valores de verdade (o falso e/ou verdadeiro) como "verumianos", digamos assim. No entanto, não temos nenhum outro pensador além de Vico que assume uma concepção particularmente na ordem do certum, como doutrina e método de investigação . Por isso, sua concepção é peculiarmente certumiana. A concepção certumiana em Vico, sua origem, influências e ramificações, será tema de um ensaio posterior, que pretendo desenvolver.
} 
ciência e consciência, como também a questão relativa ao certum e a autoridade já presente no De uno. Na secção quarta acerca Do Método, Vico deixa claro que a Scienza Nuova rege-se por uma filosofia da autoridade, como podemos observar:

“- que, entretanto se governassem com o certo da autoridade, isto é, com o mesmo critério que usa esta crítica metafísica, que é o senso-comum desse gênero humano, sobre o qual repousam as consciências de todas as nações. De modo que, por esta outra principal atenção, vem a ser esta ciência uma filosofia da autoridade, que é a fonte daquilo a que os teólogos morais chamam "justiça externa"212.

A contraposição entre o verum e o certum é próprio da metafísica tradicional, que pretendeu com o conceito de racional determinar o real. Enquanto para Vico como observamos no decorrer desta tese, a finalidade da filosofia enquanto arte crítica, é a manifestação sempre nova do real, bem como a identidade entre o verdadeiro e o fato que se dá por conversão. Esta convertibilidade entre a o fazer e a verdade, fruto da latinidade, apresenta-se e expressa-se no verossímil, cuja natureza é indeterminada e cuja função é aproximar-se da verdade sem com ela identificar-se .

Temos, portanto, dois elementos intrínsecos entre si como meio de apreensão do real histórico e do fazer ciência em Vico: a concepção teológica da unidade entre mente e corpo e o conceito do verum factum. Ambos convertíveis, e por isso capazes de assegurar a justificação da concepção viquiana. Daí atinarmos para a convertibilidade entre filologia e filosofia.

Angela Isoldi, nos dá de forma cabal, tudo aquilo que desenvolvemos em virtude de uma justificação e fundamentação da concepção viquiana:

${ }^{212}$ Ibidem, [Cf., Secção Quarta, Do método, § 350, p. 188; Ei., p. 246]. 
“Através de uma longa série de considerações e de desenvolvimento sobre a concepção de Vico, como vimos, determinamos uma particular solução da conversão entre o certum e o verum na realidade de uma consciência animada pela coincidência da razão com os sentidos. A validade, a verdade da certeza humana não se realiza através de um processo de adequação extrínseca por uma verdade transcendente, mas através de um processo de concreta extrisincalidade da intrínseca racionalidade que anima a existência humana. Tal processo não tende a adequar-se diretamente por uma ordem pré-constituída, mas realiza sua verdade somente através da criação de uma ordem real, que traz da consciência a sua existência e que para a consciência retorna o seu essencial significado. Nesta coincidência que permite a identificação na consciência humana do princípio criador e aquele re-cognitivo da história, a origem da história como res gesta e como historia rerum gestarum, Vico encontra o cumprimento da sua indagação sobre a possibilidade de realizar uma sapiência que sintetize a exigência da verdade e aquela da certeza"213.

O conceito verum-factum é de suma importância na concepção viquiana, porque lhe permitiu a conversão entre o certum e o verum, pelo qual foi possível considerar a semelhança entre Deus e o homem através do fazer e conhecer. Assim como Deus criou o mundo, o homem é capaz de criar o conhecimento finito; é capaz de conviver numa só substância, corpo e alma, sentido e espírito considerando a relação entre a vis veri latente nos sentidos desde os primórdios. Desse modo, o homem constitui a sua história e constrói as suas instituições, uma vez que a ação de Deus no ordem do mundo é

\footnotetext{
213 Angela Isoldi, G.B.Vico, La vita e Le opere, [Cf., cap. V, La storia come síntese di Provvidenza e libero arbítrio, La Scienza Nuova come conclusione della precedente problemática, p. 324-325].
} 
providente, isto é, propiciou ao homem todas as condições naturais para o seu amadurecimento, tornando-o capaz de alcançar a idade da razão.

"Contra os sistemas da metafísica apriorística que oferecem muito facilmente acesso à crítica diluindo a ânsia humana pela verdade e autorizando atitudes abertamente antimetafísicos, e contra os possíveis desenvolvimentos céticos que estas atitudes haviam revelado, Vico reivindica finalmente a possibilidade de uma metafísica garantida pela plena realização do princípio do verum factum na realidade da história. A história como mundo feito pelos homens em virtude de suas idéias, é cognoscível com verdade pela mesma mente que a criou, e por isso se põe como o fundamento indestrutível de uma nova metafísica. No mundo dos animais humanos, que é o mundo civil, ou seja, o mundo das nações, o filósofo descobre o mundo das mentes humanas, isto é , a ligação dos sentidos com a racionalidade, com a mente pura que é Deus, e este lhe permite de realizar uma metafísica como teologia civil raciocinada pela providência divina, metafísica que é síntese de filosofia e filologia, ou como também disse Vico, filosofia da autoridade, isto é, penetração e explicação da vis veri que permite à autoridade de por-se como princípio daquela ordem que constitui a essência da vida civil", 214

A partir dessa concepção, soube Vico modelar seu método derivado da crítica filológica, permitindo-lhe alcançar a origem da linguagem, ou ainda, a "origem permanente" como diz Coseriu, que nada mais é, senão o devir grego, ou de outro modo, a surgência da linguagem que se desdobra em sons, grunhidos, uivos e palavras, numa transferência inusitada entre o homem e o mundo, enquanto processo, cuja virtus se realiza pelo ponto metafísico, elemento primeiro da existência.

${ }^{214}$ Ibid. 
Sobre a ausência, somente o certum foi capaz de incidir, bem como proporcionar a sua engenhosidade, as idas e vindas num tempo que é corsi e ricorsi, que o capacitou pela imaginação a projetar-se no passado e reconstituir a história do homem, cuja essência é mutável. Rompeu desse modo com a tradição socrática, desde a sua primigênia idade, a idade dos deuses e a idade dos heróis, engendrando assim, as duas primeiras fases de uma História Ideal Eterna proporcionada pela divina providência. 


\section{BIBLIOGRAFIA}

\section{OBRAS FONTE}

1. Vico, Giambattista A Ciência Nova, tradução, Marco Luchesi, Ed. Record, São Paulo, 1999

2. __ Autobiografia, Poesie, Scienza Nuova, a cura di Pasquale Soccio, Garzanti Editore s.p.a., Milano, 1983.

3. __ Ciência Nova, tradução do original italiano intitulado Principi di Scienza Nuova, segundo o texto de Fausto Nicolini, Riccardi Ricciardi Editore, Edição as Fundação Calouste Gulbenkian, traduçaõ Jorge Vaz de Carvalho, Prefácio de Antonio M Barbosa de Melo, Lisboa, 2005.

4. __ La Scienza Nuova, introdizione e note di Paolo Rossi,RCS libri Milano, 2004

5. ___ Opere Filosofiche, Introduzione di Nicola Badaloni, Sansoni Editore, Firenze, 1971.

6. , Opere Giuridiche, Il diritto Universale, introduzione di Nicola Badaloni,

Sansoni Editore, Firenze, 1974

7. ___ Principios de ciência nueva I/II, introducción de J.M.Bermudo,Ediciones

Folio, S.A., Barcelona, 2002. 


\section{OUTRAS FONTES}

1. Aristóteles, Metafísica, Introducion Miguel Candel, Traducion Patricio de Azcárate, Editora Espasa Calpe, Madrid, 2006.

2. Descartes, Meditações, Os Pensadores, Ed. Abril Cultural, São Paulo, 1983.

3. Dante, Alighieri, De monarchia I, II, in Dante Alighieri, Tutte Le opere, a cura di Blasucci, Sansoni, Firenze, 1965.

4. Galileu Galilei, O Ensaiador, Os Pensadores, Ed. Abril Cultural, São Paulo. 1983.

5. Gracián, B., Agudeza y arte de ingenio, in B. Gracián, Obras Completas, Aguilar, Madrid 1967.

6. Guicciardini, Ricordi, Introduzione, note e commenti di Emilio Pasquini, Garzanti Editore, Milano, 1999.

7. Homero, Ilíada, Tradução de Odorico Mendes, W.M. Jackson Inc., São Paulo, 1950.

8. Muratori, L. A., Della perfetta poesia italiana, a cura di A. Ruschioni 2voll., Marzorati, Milano 1971

9. Platão, Diálogos Teeteto e Crátilo, tradução Carlos Alberto Nunes, Ed. UFPa., Belém, 1973.

10. __ A República, Fundação Calouste Gulbenkian, 6 edição, Lisboa, 1990. 


\section{OBRAS CRÍTICAS}

1. Amério, Franco, Introduzione alle Studio do G. B. Vico, Torino, 1947.

2. Apel, Karl Otto, L'idea di lingua nella tradizione dell'umanesimo da Dante a Vico, Società editrice il Mulino, Bologna, 1963

3. Auerbach, Di Erich, San Francesco Dante Vico, De Donato editore, Bari, Italia, 1970

4. Badaloni, Nicola, Introduzione a Vico, Editori Laterza, Roma-Bari, 1984, Settima edizione 2008 .

5. Battistini, A., La sapienza retorica di Giambattista Vico, Guerini e associati, Milano, 1995.

6. Berlin, Isahia, Vico e Herder, tradução de Juan Antonio Gili Sobrinho, Ed. UNB, Brasilia, 1976.

7. ___ Estudos sobre a Humanidade, tradução Rosaura Eichenberg, Companhia das Letras, São Paulo, 2002.

8. Bosi, Alfredo, O Ser e o Tempo da Poesia, Ed. Cultrix, São Paulo, 2000.

9. Cacciatore,G., Gessa-Kurotschka,V.,Poser,H., Sanna,m., La filosofia Pratica tra Metafisica e Antropologia nll'etá di Wolff e Vico, Alfredo Guida Editore, Napoli, 1997.

10. Caianiello,S., Vviana,A., Vico nella storia della filologia, Alfredo Guida Editore, Napoli, 2003.

11. Croce, Benedetto, La Filosofia di Giambattista Vico, Bari, Itália, 1947 
12. Le fonti della gnosiologia vichiana, in Saggio sullo Hegel, Bari, 1913.

13. Damiani, Alberto Mario, Domesticar a los Gigantes, Sentido y Praxis em Vico, UNR Editora, Argentina, 2005.

14. Fubini, Mario, Stile e Humanità di Giambattista Vico, Riccardo Ricciardi Editore, Milano-Napoli, 1965

15. Galeazzi, U., Ermeneutica e storia in Vico, Japadre Editore, L'aquila-Roma, 1993.

16. Guido, Humberto, A positivação da história como negação do projeto de Vico para as Ciências Humanas, Educação e Filosofia, UFU, 1999.

17. A barbárie da reflexão e a decadência moral, editorial philosophia, UFU, 2002.

18. Isoldi, A.M.J., G.B.Vico, La vita e le opere, Cappelli, 1986.

19. Pagliaro, A., Giambattista Vico tra linguistica e retorica, Edizioni Schientifiche Italiane, 1968.

20. , A vida do sinal, Ensaios sobre a língua e outros símbolos, $2^{\mathrm{a}}$ edição, Fundação Kalouste Gulbenkiam, Lisboa, 1983.

21. Pontieri e outri, Giambattista Vico, nel terzo centenario della nascita, Edizioni Schientifiche Italiane, Napoli, 1968.

22. Rossi, Paolo, Os sinais do tempo, Tradução, Julia Mainardi, Companhia da letras, São Paulo, 1992.

23. Le sterminitate antichità, studi vichiani, Nistri-Lischi Editori, Pisa, 1969.

24. Ruggiero, G., La filosofia moderna/da Vico a Kant, Bari, Gius.Laterza \& Figli, Firenze, 1943. 
25. Tagliacozzo,G, e di altri, Leggere Vico, Introduzione a cura di Emanuele Riverso, Spirali Edizioni, Milano, 1982.

26. Verene, D.P., Vico, La Scienza della fantasia, a cura di Franco Voltaggio, Prefazione di Vittorio Mathieu, Armando Armando, Roma, 1990.

\section{OBRAS CONSULTADAS}

1. , C. Keller, V., Bastos L., Aprendendo Lógica, Editora Vozes, Petrópolis, 2004.

2. A Água e os Sonhos, Livraria Martins Fontes editora, São Paulo, 1989.

3. Bachelard, Gaston, A Terra e os devaneios da Vontade, Livraria Martins Fontes Editora, São Paulo, 1991.

4. Barthes, R., O grau Zero da Escrita, tradução, Maria Margarida Barahona, Edições 70, Lisboa, 1971.

5. Bergson, Henri, Matéria e Memória, tradução Paulo Neves da Silva, Livraria Martins Fontes Editora, São Paulo, 1990.

6. Bulfinch, Thomas, O livro de Ouro da Mitologia, história de deuses e heróis, tradução David Jardim Júnior, Ediouro Publicações S/A, Rio de Janeiro, 2002.

7. Cavallo, Michele, Psicoterapia Teatrale, Schede di lavoro a cura del docente, Roma, 2004-05.

8. Chomsky, Noam, Reflexões sobre a linguagem, Livraria Martins Fontes, São Paulo, 1975.

9. Coelho, Eduardo Prado, Estruturalismo, antologia de textos teóricos, Introdução a um pensamento cruel: estruturas, estruturalidade, e estruturalismos, tradução 
Maria Eduarda Reis Colares, Antonio Ramos Rosa, Eduardo Prado Coelho, Livraria Martins Fontes Editora, São Paulo.

10. Copi, Irving, Introdução à Lógica, tradução Alvaro Cabral, Editora Mestre Jou, São Paulo, 1974.

11. Coseriu, E., O hoemem e sua linguagem, Presença edições, Rio de Janeiro, 1987.

12. Pensar para El nuevo siglo Giambattista Vico y La cultura europea, Editores, Emilio Hidalgo-Serna, Massimo Marassi, Jose M. Sevilla, José Villalobos, vol. I, Lenguaje, retórica y poética filosófica, Editora La cittá Del sole, 2001.

13. De Libera, Alan, A Filosofia Medieval, tradução Nicolás Nyimi Campanário, Yvone Maria de Campos Teixeira da Silva, Edições Loyola, São Paulo, 2004.

14. Fiker, Raul, Conhecer e o Saber em Francis Bacon, Editora Nova Alexandria, São Paulo, 1996.

15. Gadamer, Hans-Georg, Verdade e Método, tradução Flávio Paulo Meurer, Ed. Vozes, Petrópolis, 1999.

16. Husserl, E., As Conferências de Paris, Edições 70, Lisboa.

17. Kneller,G.F., A Ciência como atividade humana, Zahar Editores, Rio de Janeiro, 1980.

18. Moles, A., A criação científica, tradução Gita K. Guinsburg, Editora Perspectiva, São Paulo, 1981.

19. Nunes, Benedito, O drama da linguagem, Clarice Lispector, Ed. Ática, São Paulo, 1995.

20. Peirce, C.S., Semiótica, Tradução, José Teixeira Coelho Neto, Ed. Perspectiva, São Paulo, 1977. 
21. Popper, Karl, A Lógica da Pesquisa Científica, tradução Leonidas Hegenberg, Octanny Silveira da Mota, Editora Cultrix, São Paulo, 1972.

22. Ricoeur, Paul, O Conflito das Interpretações, Imago Editora, Rio de Janeiro, 1978.

23. Todorov, Tzvetan, Teorias do símbolo, Trad. Maria de Santa Cruz, Ed. 70, Lisboa, 1977.

24. Vilhena, M., Pequeno Manual de Filosofia, Editora Sá da Costa, Lisboa, 1974.

25. Wittgenstein, L., Tractatus Logico-Philosophicus, tradução, Luiz Henrique Lopes dos Santos, Edusp, SP, 1994.

\section{TEXTOS ON-LINE}

1. Galeazzo G., Il Vico e due grammatici latini del cinquecento, texto Internet.

2. Garin, E., A propósito di Vico e Hobbes, Schede e Spunti.

3. Gensini, Stefano, Linguaggio e natura umana: Vico, Herder e la sfida di Cartesio, Laboratorio dell'ISPF, 2005.

4. Gigante, Marcelo, Vico Nelle Storie della Filologia Classica, texto internet.

5. Hernandez, S.R., Las fuentes escritas de Grecia, Laboratorio dell'IPSF, 2005.

6. Nietzsche, F., Homero e a filologia clássica, traduçaõ, apresentação e notas, Juan A. Bonaccini, Princípios, Natal, vol. 13, nº 19-20, jan./dez. 2006,p. 169199.

7. Patella,Giuseppe, Il corpo si dice in molti modi, La sapienza corporea di G.Vico, Laboratorio dell'ISPF, 2005. 
8. Piro, Francesco, Sull1antropologia dei rudes prima di Vico. Immaginazione, credulitá, passionalitá, Laboratorio dell'ISPF, 2005.

9. Quiroga, Pedro López Barja, El cuerpo político: La fábula de Menenio Agripa, 2007.

10. Riva, Vico e Il mostro civile, in "Bolletino Del Centro di Studi Vichiani", XXXIII, 2003.

11. Rossi, P., Critica: Giambattista Vico, Vico e Il suo tempo, Aggiornamento 2002, Luiggi de Bellis.

12. Sanna, Manuela, Nature Discordi e corpi fantastici, laboratorio dell'ISPF, 2005.

13. Trabant, Jürgen, Grido, Canto, Voci, Laboratorio dell'ISPF, 2005.Visconti,

\section{DICIONÁRIOS}

1. Brandão, Junito, Dicionário mítico Etimológico, Ed. Vozes, Petrópolis, 2000.

2. Dubois,Jj., e outros, Dicionário de Lingüística, Ed. Cultrix, São paulo, 2006.

3. Mondin, Battista, Dizionario Enciclopedico Del Pensiero di San Tommaso D’Aquino, Edizioni Studio Domenicano, Bologna, 2000.

4. Mora, J.Ferrater, Dicionário de filosofia,, Edições Loyola, São paulo, 2001.

5. Saraiva, F.R. dos Santos, Novíssimo Dicionário Latino-Português, Livraria Garnier, Rio de Janeiro, 2000. 